\title{
GEOHYDROLOGY OF THE ALBIN AND LA GRANGE AREAS, SOUTHEASTERN WYOMING
}

U. S. GEOLOGICAL SURVEY

Water-Resources Investigations 76-118 Open-File Report

Prepared in cooperation with the Wyoming State Engineer Cheyenne, Wyoming

WYOMING 


\begin{tabular}{|c|c|c|}
\hline TA & 1. Report No. & 3. \\
\hline \multirow{2}{*}{\multicolumn{2}{|c|}{$\begin{array}{l}\text { 4. Title and Subtitle } \\
\text { GEOHYDROLOGY OF THE ALBIN AND LA GRANGE AREAS, } \\
\text { SOUTHEASTERN WYOMING. }\end{array}$}} & $\begin{array}{l}\text { 5. Report Date } \\
\text { November } 1976\end{array}$ \\
\hline & & \multirow[b]{2}{*}{ 8. Performing Organization Rept. } \\
\hline \multicolumn{2}{|c|}{$\begin{array}{l}\text { 7. Author(s) } \\
\text { William B. Borchert }\end{array}$} & \\
\hline \multirow{2}{*}{\multicolumn{2}{|c|}{$\begin{array}{l}\text { 9. Performing Organization Name and Address } \\
\text { U.S. Geological Survey, Water Resources Division } \\
4020 \text { House Avenue } \\
\text { Cheyenne, Wyoming } 82001\end{array}$}} & 10. Project/Task/Work Unit No. \\
\hline & & 11. Contract/Grant No. \\
\hline \multirow{2}{*}{\multicolumn{2}{|c|}{$\begin{array}{l}\text { 12. Sponsoring Organization Name and Address } \\
\text { U.S. Geological Survey, Water Resources Divisic } \\
4020 \text { House Avenue } \\
\text { Cheyenne, Wyoming } 82001\end{array}$}} & $\begin{array}{l}\text { 13. Type of Report \& Period } \\
\text { Covered } \\
\text { Final } \\
\end{array}$ \\
\hline & & \\
\hline \multicolumn{3}{|c|}{$\begin{array}{l}\text { 15. Supplementary Notes } \\
\text { Prepared in cooperation with the Wyoming State }\end{array}$} \\
\hline \multicolumn{3}{|c|}{$\begin{array}{l}\text { 16. Abstracts The Albin and La Grange areas are two adjoining different hydrologic areas. } \\
\text { Since ground water is the only source of water for irrigation in the Albin area, } 44 \\
\text { irrigation wells have been drilled since } 1968 \text { and developed in conjunction most1y with } \\
\text { center-pivot sprinkler systems that in } 1974 \text { irrigated about } 6,980 \text { acres ( } 2 \text {, } 220 \text { hectares) } \\
\text { Most irrigation wells are developed in channel deposits of the Ogallala Formation of } \\
\text { late Miocene. Water levels in parts of these channel deposits have declined about } 4 \text { to } \\
7 \text { feet (1 to } 2 \text { meters) since pumping began in } 1968 \text {. } \\
\text { In the La Grange area, lands are irrigated by surface water, ground water or a } \\
\text { combination of both. The best producing wells on an average are those completed in both } \\
\text { the Brule Formation of oligocene age and the alluvium. Secondary porosity was located } \\
\text { and evaluated in the Brule using caliper logs, an Acoustic Borehole Televiewer and } \\
\text { geophysical logs. From the spring of } 1970 \text { to the spring of 1974, hydrographs of wells } \\
\text { in parts of the La Grange area show water-level rises of about 5 feet (2 meters) result- } \\
\text { ing from the net effect of surface-water recharge and ground-water pumpage. Throughout } \\
\text { the La Grange area no significant annual water-table declines have occurred. It is } \\
\text { unlikely that irrigation wells pumping near Horse Creek have caused significant direct } \\
\text { streamflow depletion. }\end{array}$} \\
\hline \multicolumn{3}{|c|}{$\begin{array}{l}\text { Analysis. T7a. Descriptors } \\
\text {-water movement, *Water-level fll } \\
\text { Water table, Irrigated land, Ir } \\
\text { Borehole geophysics, Water ana. }\end{array}$} \\
\hline
\end{tabular}

17b. Identifiers/Open-Ended Terms

Pumpage, Secondary permeability

17c. COSATI Field'Group

\begin{tabular}{|c|c|c|}
\hline $\begin{array}{l}\text { 18. Availability Statement } \\
\text { No restriction on distribution }\end{array}$ & $\begin{array}{l}\text { 19. Security Class (This } \\
\text { Report) } \\
\text { UNCLASSIEIED }\end{array}$ & $\begin{array}{c}\text { 21. No. of Pages } \\
72\end{array}$ \\
\hline & $\begin{array}{l}\text { 20. Security Class (This } \\
\text { Page } \\
\text { UNCI.ASSIFIED }\end{array}$ & 22. Price \\
\hline
\end{tabular}


GEOHYDROLOGY OF THE ALBIN AND LA GRANGE AREAS, SOUTHEASTERN WYOMING

By William B. Borchert

Water-Resources Investigations 76-118

Open-File Report

Prepared in cooperation with the

Wyoming State Engineer

Cheyenne, Wyoming

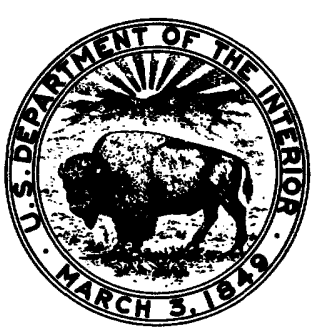

November 1976 


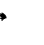




\section{UNITED STATES DEPARTMENT OF THE INTERIOR \\ Thomas S. Kleppe, Secretary \\ GEOLOGICAL SURVEY \\ V. E. McKelvey, Director}

\section{OPEN-FILE REPORT}

For additional information write to:

U.S. Geological Survey

Water Resources Division

4020 House Avenue, P.0. Box 2087

Cheyenne, Wyoming 82001 
Abstract--

Introduction-_-

Purpose and scope of the investigation-_- 3

Location and extent of the areas-_- 3

Previous investigations-- 5

We11-numbering system--_- 5

Use of metric units-_- 7

Acknowledgments-_-_- 8

Geohydrology of the Albin area- 8

Arikaree Formation-_-_-_- 8

Distribution and character-_ 8

Hydraulic properties-_- 9

Oga1lala Formation-_-_-_- 13

Distribution and character-_- 13

Hydraulic properties- 14

Irrigation development-_-_- 18

Irrigation wells- 18

Ground-water pumpage--_- 19

We11 interference-- 19

Irrigated acreage--_-_- 21

The water table-_-_- 22

Configuration--_-_-_-_- 22

F1uctuation-_- 23

Chemical quality of the ground water-_- 26

Summary and conclusions-_- 26

Geohydrology of the La Grange area-_- 28

Brule Formation-_-_- 29

Distribution and character-_- 29

Secondary permeability and porosity- 30

Hydraulic properties- 37

A1luvium-- 38

Distribution and character-_- 38

Hydraulic properties-_- 38

Irrigation development-_- 40

Surface water-_- 42

Irrigation wel1s-_-_-_-_- 46

Ground-wațer pumpage--_-_-_- 52

Irrigated acreage-_- 54

The water table-_- 54

Configuration--_- 54

F1uctuation--_-_-_-_-_- 55

Stream-aquifer relationship-_- 63

Chemical quality of the water- 65

Summary and conclusions-_- 67

References cited-_- 70 


\section{ILLUSTRATIONS}

Page

Figure 1. Index map of southeastern Wyoming showing location of Albin and La Grange areas- 4

2. Diagram showing we11-numbering system-- 6

3. Map showing geology and structure contours on base of Ogallala Formation-

4. Graph showing specific-capacity frequency of irrigation wells in the Arikaree Formation- 11

5. Map showing saturated thickness of Ogallala Formation, 1973 and 1974, and irrigated acreage in the Albin area, 1974- In pocket

6. Graph showing estimated monthly ground-water pumpage for irrigation 1968-74 in the Albin area-- 20

7. Map showing water-table contours and well locations in the Albin area, 1973 and 1974------ In pocket

8. Hydrographs of water-level fluctuations in areas affected by pumping in the Albin area- 25

9. Map showing geology and saturated thickness of the alluvium in the La Grange area, 1973-_- In pocket

10. Photograph of portion of Borehole Televiewer $10 \mathrm{~g}$ for wel1 19-61-13baa showing secondary porosity in the Brule Formation and caliper log for same interval-----

11. Caliper $10 \mathrm{~g}$, gamma $10 \mathrm{~g}$, and gamma-gamma $10 \mathrm{~g}$ for well 19-61-13baa-_-

12. Graphs showing annual (calendar year) discharge of Horse Creek at Wycross Ranch near La Grange, Wyoming, and annual precipitation at La Grange, 1966-73-- -

13. Graph showing estimated annual ground-water pumpage 1962-74 in the La Grange area-C-

14. Map showing irrigated acreage in the La Grange area, 1974 In pocket

15. Map showing water-table contours and wel1 locations in the La Grange area, 1973In pocket

16. Graph showing estimated monthly ground-water pumpage 1972-74 in the La Grange area 


\section{ILLUSTRATIONS--continued}

Page

Figure 17. Hydrographs showing discharge of Horse Creek at Wycross Ranch in 1973, water-level fluctuations at wells 19-61-4abc and 20-61-23ccc, and daily precipitation 1973-74 at La Grange-

18. Hydrographs of seasonal water-level fluctuations $1970-74$

19. Graph showing estimated monthly diversions of

Horse Creek No. 1 Ditch-

20. Hydrographs of water-level fluctuations, and average and annual departure from normal annual precipitation at La Grange, 1949-74

\section{TABLES}

Table 1. Records of selected wells in the Albin area--------

2. Chemical analyses of ground water in the Albin area----

3. Records of selected wells in the La Grange area------

4. Chemical analyses of ground water in the La Grange area-C- 


\section{GEOHYDROLOGY OF THE ALBIN AND LA GRANGE AREAS, SOUTHEASTERN WYOMING}

By William B. Borchert

\section{ABSTRACT}

The Albin and La Grange areas are adjoining but hydrologically different areas in which use of ground water has increased rapidly in recent years. The Albin area, located in Laramie County, is about 750 feet (230 meters) higher than the La Grange area, most of which is in Goshen County to the north.

Dryland farming is the general practice throughout the Albin area; however, since 1968, irrigated farming has become prevalent in parts of the area. Thirty-four irrigation wells have been drilled since 1968, mostly for use with center-pivot sprinkler systems that irrigated about 6,980 acres $(2,820$ hectares) in 1974. Ground water is the only source of water for irrigation. Some irrigation wells are developed in the Arikaree Formation of early Miocene age; however, most are developed in channel deposits of the Ogallala Formation of late Miocene age. Irrigation wells in the channel deposits penetrate from 85 to 170 feet (26 to 52 meters) of saturated sand, silt, and gravels and most are capable of yielding from 800 to 1,000 gallons per minute (50 to 63 liters per second). Water levels in parts of these channel deposits have declined about 4 to 7 feet ( 1 to 2 meters) since pumping began in 1968 . In the area southeast of Albin, about 4 feet ( 1 meter) of the 7 feet ( 2 meters) of decline can be attributed to a 55 percent increase in ground-water pumpage in 1974 over that in 1973.

During 1974, about 10,110 acres (4,092 hectares) were irrigated in the La Grange area using surface water from Bear Creek and Horse Creek, ground water, or a combination of surface water and ground water. A11 the 71 irrigation wells pumped from the Brule Formation of the White River Group of Oligocene age, the alluvium of Pleistocene and Holocene age, or from both formations. Wells with the highest yields are those northeast of La Grange completed in the Brule or in both the alluvium and Brule. Specific capacities for these wells range from 45 to 230 gallons per minute per foot ( 9.3 to 47.6 liters per second per meter) of drawdown. 
The Brule Formation, which consists primarily of argillaceous siltstone, has low primary permeability. Wells yield enough water for irrigation from zones of secondary permeability in the Brule. Zones of secondary porosity were studied in two wells in the La Grange area using caliper logs and acoustic borehole televiewer logs. At intervals of known secondary porosity, an evaluation was made of the response of geophysical logs.

From the spring of 1970 to the spring of 1974, wells northeast of La Grange had water-level rises of about 5 feet ( 2 meters), mostly the result of recharge from surface water. Water-level declines west and northwest of La Grange from the spring of 1973 to the spring of 1975 were a result of increased pumpage and of decreased precipitation during 1974. Based on streamflow measurements during the irrigation season, it appears unlikely that irrigation wells have caused any significant direct streamflow depletion in Horse Creek.

\section{INTRODUCTION}

The Albin and La Grange areas are part of the High Plains section of the Great Plains physiographic province (Fenneman, 1946). The Albin area is part of the original High Plains; whereas, the La Grange area is about $750 \mathrm{ft}(230 \mathrm{~m})$ lower, where the original High Plains surface has been deeply eroded. The eroded area, referred to as Goshen Hole, is shown in figure 1 as the area east of the irregular dashed line and north of the Albin area. The Albin and La Grange areas are adjoining but hydrologically different areas in which use of ground water has increased rapidly in recent years. Normal annual precipitation at Albin is 18.26 in $(463.8 \mathrm{~mm})$. Normal annual precipitation at La Grange is 15.47 in $(392.9 \mathrm{~mm})$.

Before 1968, dryland farming was the general practice throughout the Albin area; however, since 1968, irrigated farming has become prevalent in parts of the area. There are no perennial streams in the Albin area and ground water is the only source of water for irrigation. Thirtyfour irrigation wells have been drilled since 1968, mostly for use with center-pivot sprinkler systems.

Irrigation with surface water started in the $1880^{\prime} \mathrm{s}$ in the La Grange area utilizing water from Horse Creek and Bear Creek, the only perennial streams in the area. Development of ground water started in 1936. Twenty-five irrigation wells were drilled in the next 30 years, and from 1967 to 1973 an additional 44 irrigation wells were drilled. 


\section{Purpose and Scope of the Investigation}

The purpose of this investigation was to describe the aquifers in each area, to evaluate the response of the aquifers to the present rate of withdrawal, to establish an observation-we11 network in each area, to describe the relationship between surface water and ground water in the La Grange area, and to sample ground water to determine its general quality in each area, to determine if any changes in quality are due to irrigation practices, and to provide background data for future evaluations of the effects of irrigation on water quality. Because of the increasing number of irrigation wells in the two areas, this study was begun in July 1972 in cooperation with the Wyoming State Engineer.

The following methods were used to accomplish the objectives of the study. Driller's logs from wells and test holes were studied and used for compiling maps showing saturated thickness of the Ogallala Formation of late Miocene age in the Albin area, saturated thickness of the alluvium of Pleistocene and Holocene age in the La Grange area, and structure contours on the base of the Ogallala Formation in the Albin area. Pumpage was estimated using electric power records, measured discharges, and information from owners. Aquifer tests were made in both areas to obtain aquifer parameters. Geophysical logs and an acoustic televiewer log were run in two wells in the La Grange area. Water levels were measured in as many wells as possible and measurements were used to construct water-table contour maps; monthly water-1evel measurements were made in 19 observation wells in the Albin area and 24 observation wells in the La Grange area. Diversion records made available by personnel from the State Engineer's office and streamflow measurements of Horse Creek and Bear Creek were used to evaluate the relationship between surface water and ground water in the La Grange area. Six ground-water samples in the Albin area and 18 in the La Grange area were analyzed for chemical quality.

\section{Location and Extent of the Areas}

The Albin and La Grange areas together consist of about $390 \mathrm{mi}^{2}$ $\left(1,010 \mathrm{~km}^{2}\right)--210 \mathrm{mi}^{2}\left(540 \mathrm{~km}^{2}\right)$ in the Albin area and $180 \mathrm{mi}^{2}\left(470 \mathrm{~km}^{2}\right)$ in the La Grange area--adjacent to Nebraska in southeastern Wyoming (fig. 1). The two areas are divided along the east-trending escarpment at the southern boundary of Goshen Hole, a prominent physiographic feature. The escarpment, although not prominent west of Highway 85, defines the northernmost extent of the Ogallala Formation. 

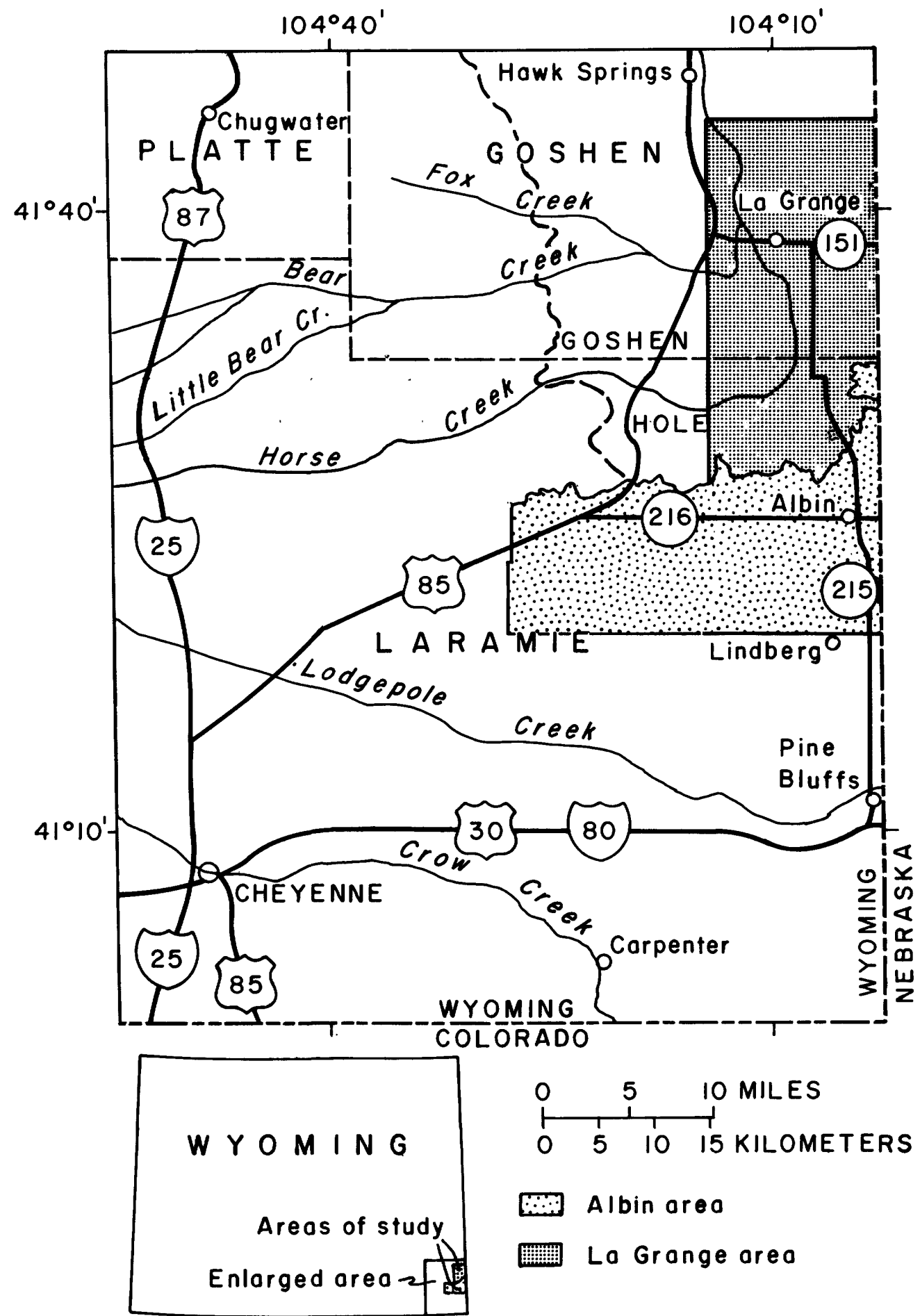

Figure I.-Location of Albin and La Grange areas. 


\section{Previous Investigations}

Several investigations of the geology and water resources of all or parts of the Albin and La Grange areas have been made. The geology, streams, and springs of the La Grange area were described by Adams (1902) in a report on the Patrick and Goshen Hole quadrangles. Schlaikjer (1935 a, b, and c) described the geology of the Goshen Hole area which includes part of the La Grange area. The ground-water resources of the Horse Creek and Bear Creek valleys were described briefly by Dockery (1940) and by Babcock and Rapp (1952). Most of the La Grange area was described by Rapp and others (1957) in their study of the geology and ground-water resources of Goshen County. Bjorklund (1959) reported on the geology and ground-water resources of the upper Lodgepole Creek drainage basin that includes the southern half of the Albin area. All of the Albin area was included in the report on the geology and groundwater resources of Laramie County by Lowry and Crist (1967).

\section{We11-Numbering System}

Wells cited in this report are identified by a number based on the Federal system of land subdivision ( $f$ ig. 2). The first number indicates the township, the second the range, and the third the section in which the well is located. The lowercase letters following the section number locate the well in the section. The first letter denotes the quarter section, the second letter the quarter-quarter section, and the third letter the quarter-quarter-quarter section [10-acre (4.0 hectares) tract]. The subdivisions of a section are lettered $a, b, c$, and $d$ in $a$ counterclockwise direction, starting in the northeast quarter. When more than one well is located in a 10-acre ( 4.0 hectares) tract, consecutive numbers starting with 1 follow the last lowercase letter of the we11 number.

This well-numbering system is also used to designate test holes, and stream-gaging sites cited in this report. 


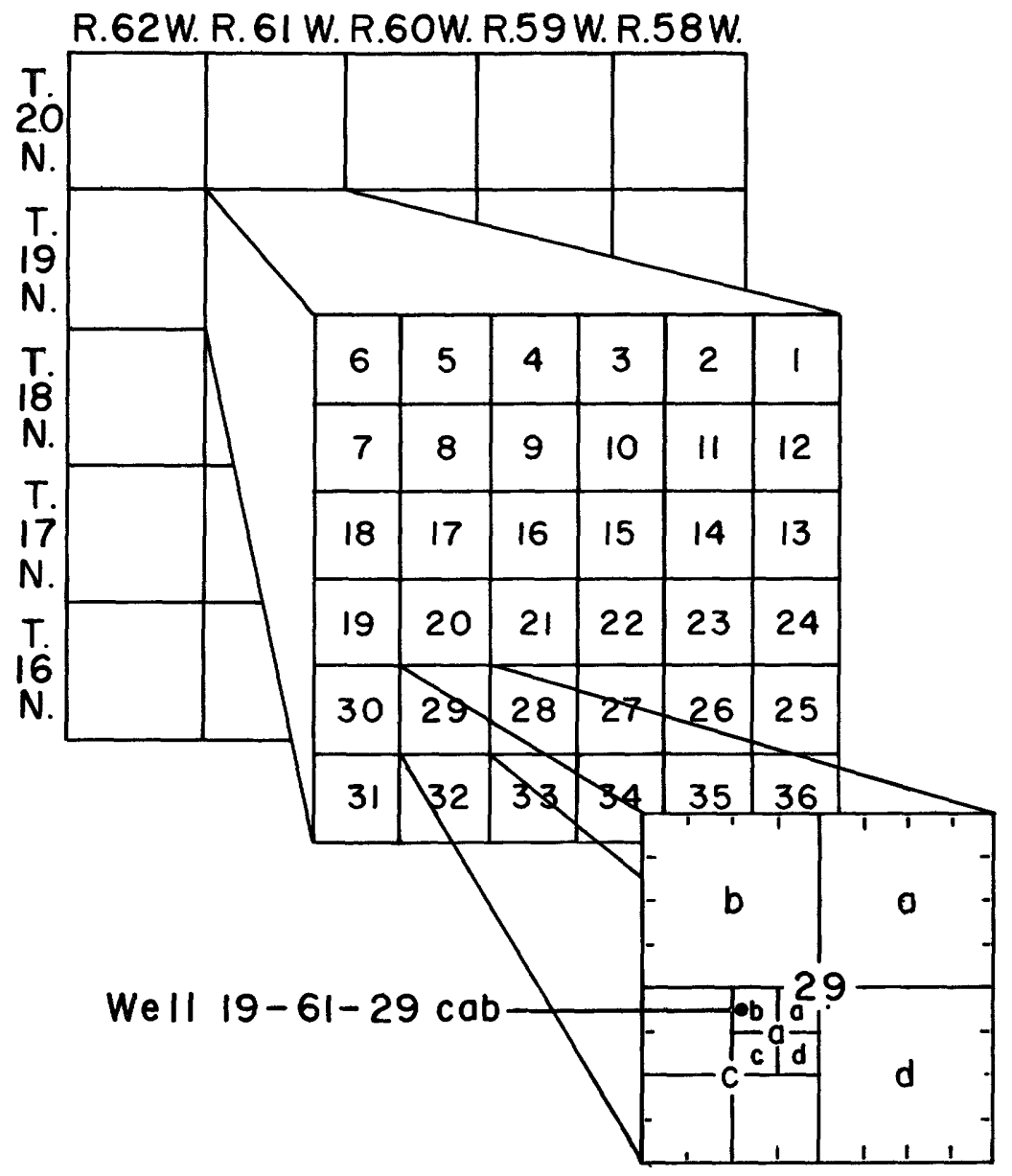

Figure 2.-Well-numbering system. 


\section{Use of Metric Units}

For those readers interested in using the metric system, metric equivalents of English units of measurement are given in parentheses in the text. The following table may be used to convert the English units of measurement used in this report to metric units. The conversion factors are shown to four significant figures in this table. The metric equivalents in the text are shown only to the number of significant figures consistant with the values for the English units.

English

acres

acre-ft (acre-feet)

acre-ft/yr

(acre-feet per year)

ft (feet)

$\mathrm{ft} / \mathrm{mi}$ (feet per mile)

$\mathrm{ft}^{3} / \mathrm{s}$ (cubic feet per second)

$\left(\mathrm{ft}^{3} / \mathrm{d}\right) / \mathrm{ft}$ (cubic feet per day per foot)

gal/min (gallons per minute)

(gal/min)/ft (gallons per minute per foot)

[(gal/min)/ft]/ft (gallons .6791 per minute per foot per foot)

in (inches)

mi (miles)

$\mathrm{mi}^{2}$ (square miles)
25.40

1.609

Multiply by

.4047

.001233

.001233

.3048

.1894

.02832

.09290

.06309

.2070

2.590
Metric

hectares

$\mathrm{hm}^{3}$ (cubic hectometers)

$\mathrm{hm}^{3} / \mathrm{yr}$ (cubic hectometers per year)

m (meters)

$\mathrm{m} / \mathrm{km}$ (meters per kilometers)

$\mathrm{m}^{3} / \mathrm{s}$ (cubic meters per second)

$\left(\mathrm{m}^{3} / \mathrm{d}\right) / \mathrm{m}$ (cubic meters per day per meter)

1/s (liters per second)

$(1 / \mathrm{s}) / \mathrm{m}$ (1iters per second per meter)

$[(1 / \mathrm{s}) / \mathrm{m}] / \mathrm{m}$ (1iters per second per meter per meter)

mm (millimeters)

$\mathrm{km}$ (kilometers)

$\mathrm{km}^{2}$ (square kilometers) 


\section{Acknowledgments}

The author appreciates the cooperation of the many well owners who supplied information about their wells and allowed discharge measurements and periodic measuring of water levels. Gordon Malm, William C. Moore, Ed Johnson, Shirley Sanders, Arthur Sherard, and George Wendt permitted the use of their wells for aquifer tests. The assistance of Curtis Meier in preparing his center-pivot sprinklers for discharge measurements and for allowing observation wells to be drilled on his land, is gratefully acknowledged. Thanks are due James Ward, Hydrographer-Commissioner for the Wyoming State Engineer's office, for providing data on surface-water diversions. Assistance of the ground-water staff at the State Engineer's office is gratefully acknowledged for providing well data and irrigated acreage information. The cooperation and assistance of well drilling companies in providing test-hole information is greatly appreciated.

\section{GEOHYDROLOGY OF THE ALBIN AREA}

Irrigation wells and test holes in the Albin area have totally or partially penetrated the Arikaree Formation of early Miocene age and the Ogallala Formation of late Miocene age. A few wells and test holes penetrated the upper part of the Brule Formation of 0ligocene age. Test holes in the south half of sec. 4, T. $16 \mathrm{~N} .$, R. $60 \mathrm{~W}$. penetrated as much as $100 \mathrm{ft}(30 \mathrm{~m})$ of the upper saturated part of the Brule. However, the Brule in this area did not yield sufficient quantities of water for domestic use. All irrigation wells are developed in either the Arikaree, the Ogallala, or a combination of both formations; therefore, emphasis is placed on describing the aquifer characteristics of these formations.

\section{Arikaree Formation}

\section{Distribution and Character}

The Arikaree Formation underlies the entire Albin area, except for two small areas (fig. 3) south and southeast of Albin. Probably erosion removed the Arikaree in these two areas before deposition of the Ogallala Formation. The extent of these areas was approximated from available driller's logs of wells and test holes in the areas.

The Arikaree consists of tan to light-gray, very fine to finegrained, partly silty, massive sandstone in the outcrops exposed in the escarpment bounding Goshen Hole. The sandstone generally is loosely to moderately cemented, but layers of well cemented, hard sandstone and beds of siltstone occur locally throughout the formation. Logs of wells and test holes indicate that locally thin zones of medium to coarsegrained sand and fine gravel occur at different depths and sometimes at the base of the Arikaree. 
The thickness of the Arikaree ranges from zero in the two areas shown in figure 3 south and southeast of Albin to about $500 \mathrm{ft}(150 \mathrm{~m})$ north of Albin along the Goshen Hole escarpment. Few data on the thickness of the Arikaree throughout the Albin area are available because most wells have not penetrated the full thickness. However, the available data indicate that the Arikaree thins south of Albin to about $110 \mathrm{ft}(34 \mathrm{~m})$ at we11 16-60-20cdd and thickens southwest of Albin to about $300 \mathrm{ft}(91 \mathrm{~m})$ in a test hole at 16-61-27bcd. Although not penetrating the full thickness of the Arikaree, we1ls 17-62-31accl and 17-63-26dbal were drilled about $300 \mathrm{ft}(91 \mathrm{~m})$ into the Arikaree.

\section{Hydraulic Properties}

The hydraulic properties of the Arikaree Formation vary somewhat from one location to another; however, in southeastern Wyoming, the Arikaree is fairly homogeneous. The Arikaree in the Albin area has not been developed to the extent it has. in other areas in southeastern Wyoming; therefore, its hydraulic properties are not well defined but are assumed to be similar to the properties found in the other areas.

Although affected by many variables, specific capacity (yield per foot of drawdown) for a specified time, usually 24 hours, can be used as a guide to the relative transmissivity of an aquifer. Transmissivity expresses the rate of flow of water in $\mathrm{ft}^{3}$ per day, through a vertical strip of aquifer $1 \mathrm{ft}$ wide extending the full height of the aquifer under a hydraulic gradient of $1 \mathrm{ft}$ per $\mathrm{ft}$. The U.S. Geological Survey prefers $\mathrm{ft}^{2} /$ day for the units of transmissivity. However in this report, the units for transmissivity are given as ( $\mathrm{ft}^{3} / \mathrm{day}$ )/ft so that the reader unfamiliar with these units can easily understand them to express a rate of flow. Generally high specific capacities indicate an aquifer of high transmissivity; low specific capacities, an aquifer of low transmissivity. 
Data from irrigation wells pumping from the Arikaree Formation in the Albin area, the Wheatland-Dwyer area about $60 \mathrm{mi}(96 \mathrm{~km})$ northwest of Albin, and the Lusk area located about $100 \mathrm{mi}(160 \mathrm{~km})$ north of Albin have been used to prepare a specific-capacity frequency graph (Walton, 1962, p. 13-14). The data for the Wheatland area were computed from information given by Weeks (1964, p. 62-64); for the Dwyer area, data were obtained from G. C. Lines (oral commun., 1974); and for the Lusk area, data were obtained from M. A. Crist (oral commun., 1974). Because specific capacity changes slowly with the duration of discharge, the time of discharge is usually reported as part of the specific-capacity data. The duration of discharge is not known for most of the specificcapacity data used in the specific-capacity frequency graph. However, it was assumed that the specific capacities were measured after a long enough time that drawdown was not drastically changing. Most wells used in this analysis normally are pumped for periods longer than 24 hours at one time and usually specific capacities were determined only for such wells. Values of specific capacity per foot of penetration were plotted against the percentage of wells on logarithmic probability paper as shown in figure 4. Specific capacity per foot of penetration is determined by dividing the specific capacity by the saturated thickness that the well penetrates. Using figure 4, the average specific capacity per foot of penetration of the Arikaree shown for each area is as follows:

$\begin{array}{ll}\text { Albin area } & -0.050[(\mathrm{gal} / \mathrm{min}) / \mathrm{ft}] / \mathrm{ft}(0.034[(1 / \mathrm{s}) / \mathrm{m}] / \mathrm{m}), \\ \text { Wheatland-Dwyer area }-0.014[(\mathrm{gal} / \mathrm{min}) / \mathrm{ft}] / \mathrm{ft}(0.010[(1 / \mathrm{s}) / \mathrm{m}] / \mathrm{m}), \\ \text { Lusk area } & -0.058[(\mathrm{gal} / \mathrm{min}) / \mathrm{ft}] / \mathrm{ft}(0.039[(1 / \mathrm{s}) / \mathrm{m}] / \mathrm{m}) \text {. }\end{array}$

The steeper the slope of the lines fitted to the data, the greater the range of the specific capacity per foot of penetration within an area. Based on the existing data, the specific capacity per foot of penetration varies more for wells developed in the Arikaree in the Albin area than for wells in the Lusk and Wheatland-Dwyer areas. However, the graph indicates that the range of specific capacity per foot of penetration for the Albin area is more similar to that range shown for the Lusk area than the range shown for the Wheatland-Dwyer areas. This implies that the range of transmissivity of the Arikaree in the Albin area is more similar to the range of transmissivity found in the Lusk area than to the range found in the Wheatland-Dwyer area. 


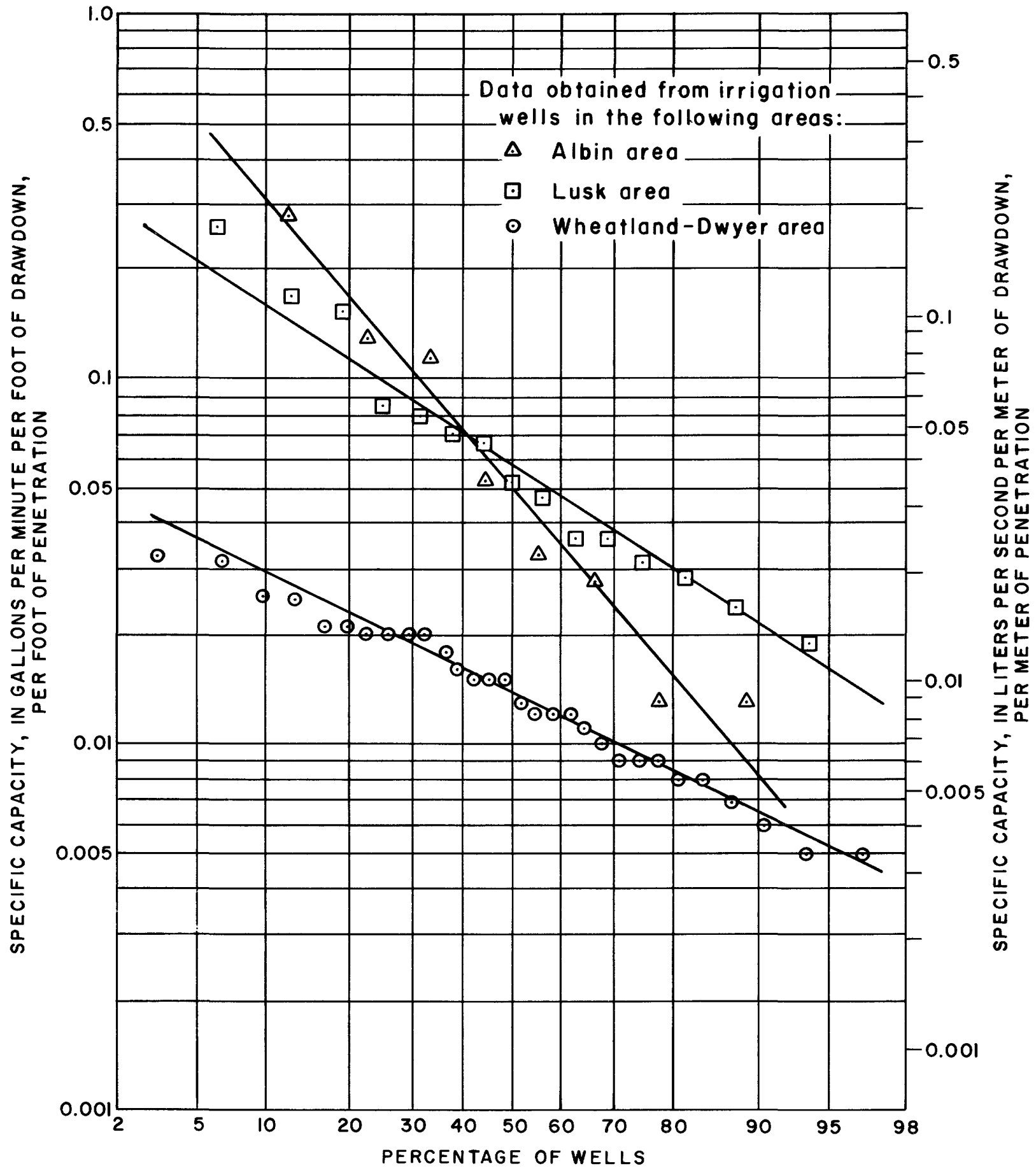

Figure 4.- Specific-capacity frequency of irrigation wells in the Arikaree Formation in southeostern Wyoming. 
Transmissivities determined from aquifer tests of the Arikaree Formation near Wheatland in Platte County, Wyoming (Weeks, 1964, p. 44) ranged from about 350 to about $1,300\left(\mathrm{ft}^{3} / \mathrm{d}\right) / \mathrm{ft}\left[32\right.$ to $\left.120\left(\mathrm{~m}^{3} / \mathrm{d}\right) / \mathrm{m}\right]$. Whitcomb ( 1965, p. 48) reported transmissivities ranging from 1,070 to $10,300\left(\mathrm{ft}^{3} / \mathrm{d}\right) / \mathrm{ft}\left[99.4\right.$ to $\left.956\left(\mathrm{~m}^{3} / \mathrm{d}\right) / \mathrm{m}\right]$ for the Arikaree near Lusk in Niobrara County, Wyoming. Data from an aquifer test of the Arikaree in the Albin area were analyzed using the Theis (1935) recovery formula and Jacob's (1950) modified nonequilibrium formula. The results of this aquifer test are shown in the following table:

\begin{tabular}{|c|c|c|c|c|c|}
\hline We11 location & $\begin{array}{c}\text { Location of } \\
\text { observation } \\
\text { well from } \\
\text { pumped well } \\
\text { (ft) }\end{array}$ & $\begin{array}{c}\text { Transmissivity } \\
{\left[\left(\mathrm{ft}^{3} / \mathrm{d}\right) / \mathrm{ft}\right]}\end{array}$ & $\begin{array}{c}\text { Storage } \\
\text { Coefficient }\end{array}$ & $\begin{array}{l}\text { Length } \\
\text { of } \\
\text { test } \\
\text { (hrs) } \\
\end{array}$ & $\begin{array}{l}\text { Date } \\
\text { test } \\
\text { started }\end{array}$ \\
\hline $\begin{array}{r}17-62-31 \text { acc1 } \\
31 \text { acc } 2 \\
31 \text { acc } 3\end{array}$ & $\begin{array}{l}\text { (pumped wel1) } \\
41 \text { (south) } \\
156 \text { (east) }\end{array}$ & $\begin{array}{l}1,240 \\
1,230 \\
3,030\end{array}$ & $\frac{---}{\overline{7.1 \times 10^{-3}}}$ & 48 & $9 / 16 / 74$ \\
\hline
\end{tabular}

1 Storage coefficient is the volume of water the aquifer releases from or takes into storage per unit surface area of the aquifer per unit change in head.

The transmissivity values obtained from this aquifer test are reasonable for the Arikaree; however, they represent hydraulic properties of the Arikaree only at the location of this aquifer test.

A wide range in transmissivity for the Arikaree Formation in the Albin area should be expected. The range in transmissivity is probably partly due to variability in sand grain size and to differences in the degree of cementation. Wells drilled in the fine sand of the Arikaree can produce maximum yields by full penetration of the aquifer, careful well design, and adequate well development. Specific capacity can be greatly affected by these factors. It is often advantageous to drill test holes in the Arikaree to determine areas where the most favorable hydrologic conditions exist for the location of a well. 


\section{Ogallala Formation}

\section{Distribution and Character}

The Ogallala Formation is the only formation exposed in the Albin area; it is the major aquifer for most of the irrigation wells. The Ogallala consists of heterogeneous deposits of silt, sand, and gravel, predominantly unconsolidated with interbedded clay layers and occasional limestone lenses. Resistant beds in the Ogallala, cemented by calcium carbonate, cap the escarpment bounding Goshen Hole along the northern boundary of the Albin area. The deposits of the Ogallala in the Albin area that are the most important for ground-water development occur generally south of Albin as coarse-grained channel deposits.

For ease of identification of these channel deposits in the Ogallala, they will be referred to throughout the text as the northern, central, or southern channel deposits. These channel deposits are generally shown by lines of equal saturated thickness of the Ogallala greater than $50 \mathrm{ft}(15 \mathrm{~m})$ on figure 5 . The northern channel deposits are those mostly in T. $17 \mathrm{~N}$., R. $60 \mathrm{~W}$. The central channel deposits are those extending from west to east through the upper half of T. 16 N., Rs. 60, 61 , and part of $62 \mathrm{~W}$. The southern channel deposits, mostly in secs. 21, $22,23,26$, and 27, T. 16 N., R. 60 W., are a broad, thick extension of the central channel deposits.

The Ogallala Formation was deposited over an eroded surface of the Arikaree Formation throughout most of the area. Coarse-grained materials in the northern channel deposits were deposited in a channel cut into the Arikaree in the western half and in a deep, steep-walled channel cut through the Arikaree into the Brule Formation in the eastern half (fig. 3 ). The best defined channel in the Brule, beginning about a mile $(1.6 \mathrm{~km})$ south of Albin, extends to the southeast into Nebraska where it bends east and then slightly northeast (V. L. Souders, oral commun., 1974). The saturated thickness of the Ogallala penetrated by test holes in the deeper parts of the northern channel deposits ranges from $120 \mathrm{ft}(37 \mathrm{~m})$ to $380 \mathrm{ft}(116 \mathrm{~m})$. The greater thickness was penetrated in a test hole drilled in Nebraska near the State line by the Conservation and Survey Division of the University of Nebraska (Smith and Souders, 1971, p. 128130). Irrigation wells in these channel deposits penetrate from $90 \mathrm{ft}$ $(27 \mathrm{~m})$ to $170 \mathrm{ft}(52 \mathrm{~m})$ of saturated thickness.

Coarse-grained materials in the central channel deposits were deposited in a channel cut into the Arikaree in T. 16 N., Rs. 61 and $62 \mathrm{~W}$. and into channels cut through the Arikaree into the Brule about the last $5 \mathrm{mi}(8 \mathrm{~km})$ near the State line (fig. 3). Saturated thickness penetrated by irrigation wells in the central channel deposits ranges from $85 \mathrm{ft}(26 \mathrm{~m})$ to $130 \mathrm{ft}(40 \mathrm{~m})$. Additional test drilling might indicate an extension of these coarse-grained channel deposits farther westward into T. $16 \mathrm{~N}$., R. $62 \mathrm{~W}$., even though present data show that the saturated thickness of the Ogallala decreases in this area (fig. 5). 
The southern channel deposits were deposited in a broad, deep, gently sloping channel cut into the Arikaree. Deposits in this channel consist of fine sand and sandy clay with gravel lenses, much finer grained than deposits in the two channels to the north which are predominantly medium to coarse-grained sand and gravel with some interbedded silt and clay.

\section{Hydraulic Properties}

An aquifer test of the Ogallala Formation was made at well 17-60-33dbb1 for 24 hours. Data from an observation we11, located $160 \mathrm{ft}(49 \mathrm{~m})$ from the pumped well, were analyzed using the Theis nonequilibrium formula (Theis, 1935) and Jacob's modified nonequilibrium formula (Jacob, 1950). Transmissivity was calculated to be about 93,600 $\left(\mathrm{ft}^{3} / \mathrm{d}\right) / \mathrm{ft}\left[8,700\left(\mathrm{~m}^{3} / \mathrm{d}\right) / \mathrm{m}\right]$.

The test site was located in the narrower part of the northern channel deposits where coarser, more permeable materials having a higher hydraulic conductivity would be more likely to occur. Hydraulic conductivity of an aquifer is a measure of the capacity of the aquifer to transmit water. It can be expressed as the rate of flow in $\mathrm{ft}^{3}$ per day through a cross-sectional area of $1 \mathrm{ft}^{2}$ under a hydraulic gradient of $1 \mathrm{ft}$ per $\mathrm{ft}$. The saturated thickness of $170 \mathrm{ft}(52 \mathrm{~m})$ at we11 17-60-33dbb1 is the greatest penetrated by any of the wells drilled in the medium to coarsegrained channel deposits. Thus, because transmissivity is directly proportional to the hydraulic conductivity and the saturated thickness, the value for transmissivity determined from this aquifer test is probably too high to be considered a representative value for all the Ogallala channel deposits. However, transmissivities greater than $15,000\left(\mathrm{ft}^{3} / \mathrm{d}\right) / \mathrm{ft}\left[1,400\left(\mathrm{~m}^{3} / \mathrm{d}\right) / \mathrm{m}\right]$ probably can be expected for most of the channel deposits with a saturated thickness of at least $100 \mathrm{ft}$ (30 m) (fig. 5).

Specific capacities of wells drilled in the northern channel deposits in the Ogallala Formation range from 50 to 229 (gal/min)/ft [10 to $47(1 / \mathrm{s}) / \mathrm{m}$ ] of drawdown (table 1$)$. These high specific capacities, in addition to the high transmissivity determined by the aquifer test at well 17-60-33dbb1, indicate that the transmissivity of the Ogallala in the Albin area generally is highest in this channel deposit southeast of Albin .

The specific capacity for irrigation wells drilled in the other Ogallala channel deposits in the Albin area range from 7 to 101 (gal/min)/ft [1.4 to $21(1 / \mathrm{s}) / \mathrm{m}]$ of drawdown. The well with the lowest and the well with the highest specific capacity values have about the same saturated thickness and are located within half a mile $(0.8 \mathrm{~km})$ of each other in the central channel deposits. This illustrates the heterogeneity of the Ogallala Formation even in these coarser, more permeable channel deposits. Test drilling may be used to pinpoint sections of maximum permeability and saturated thickness. Complete penetration of the aquifer by a well is necessary for maximum yields and minimum drawdowns. 


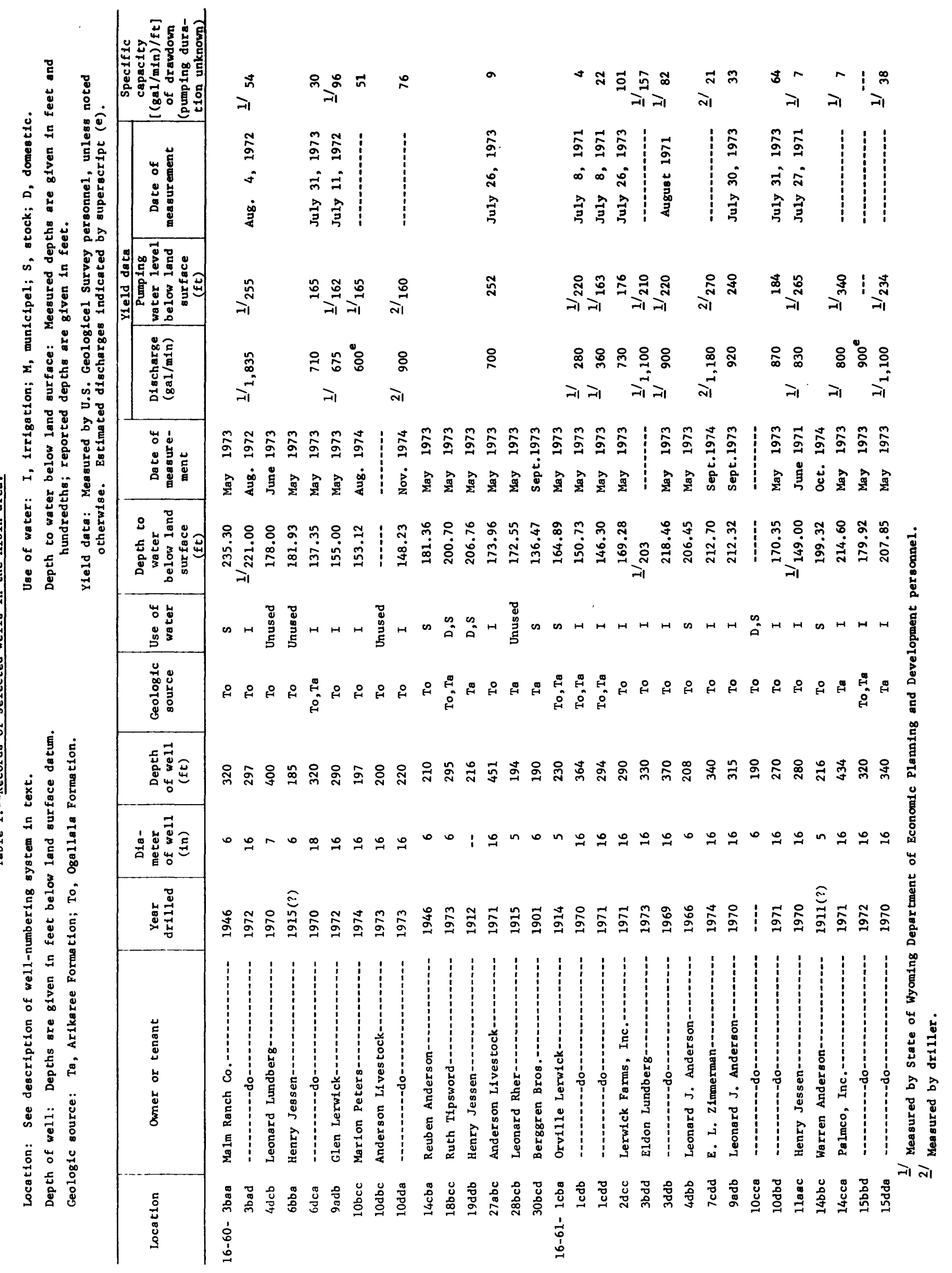




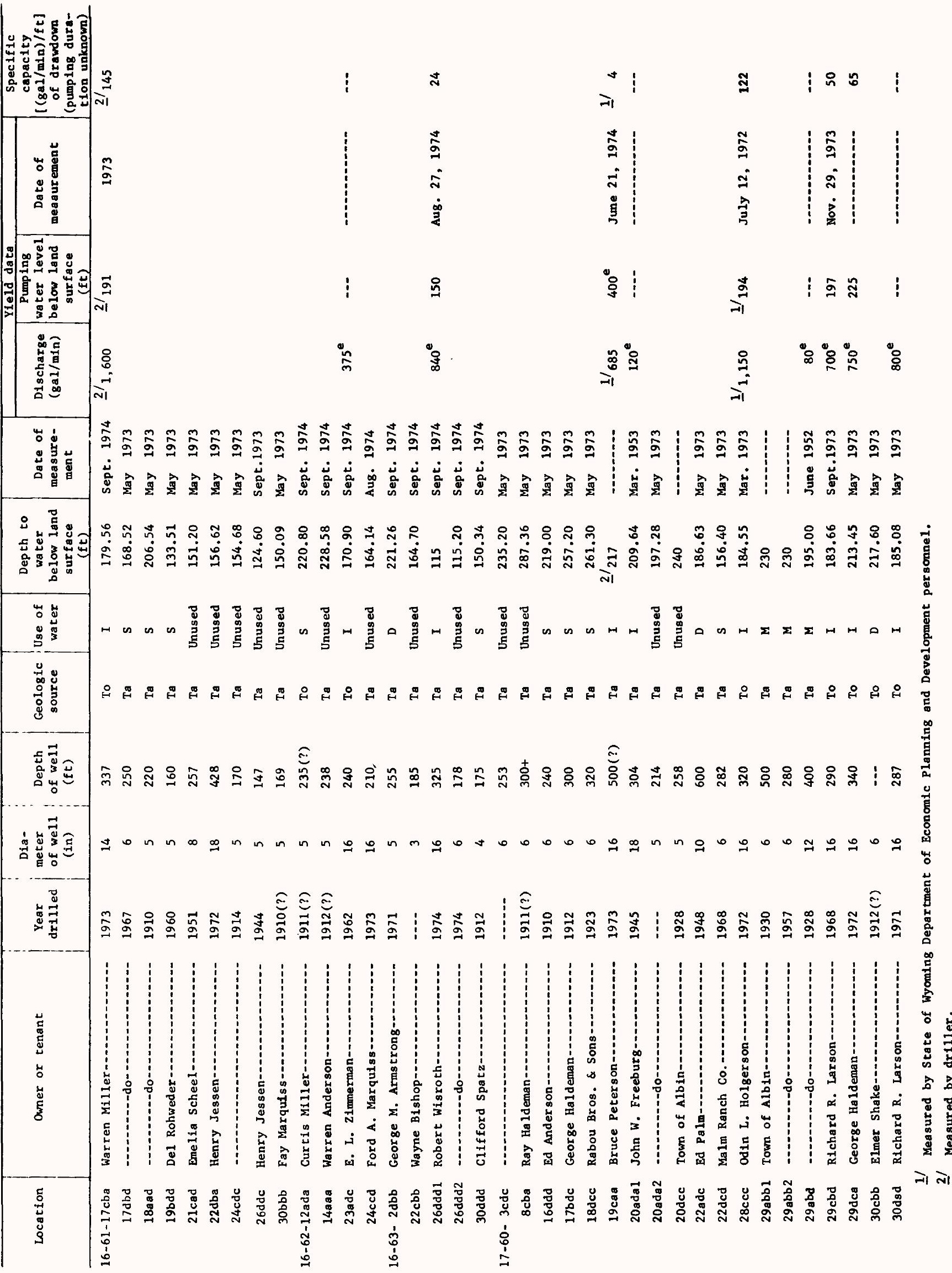




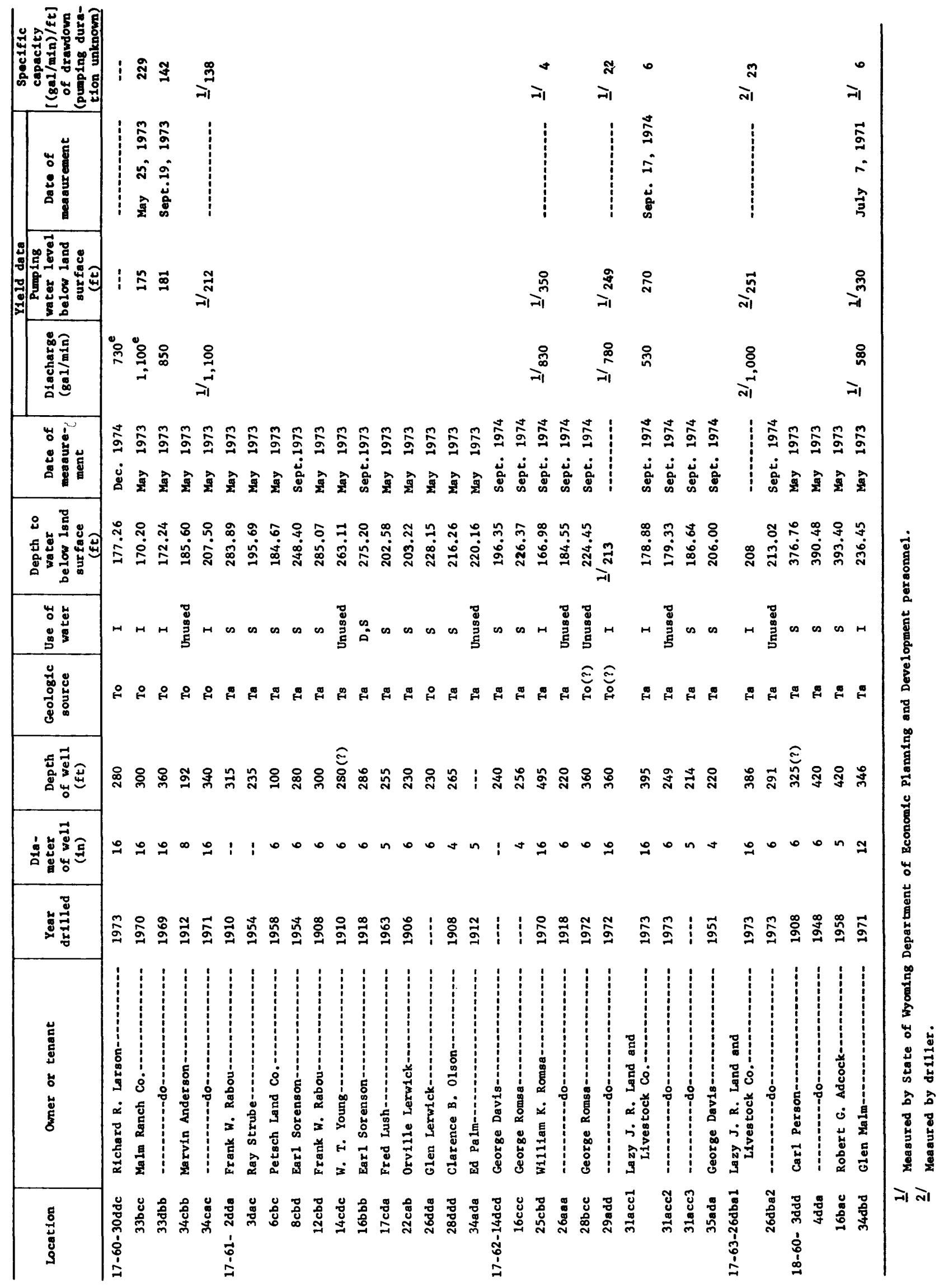




\section{Irrigation Development}

Irrigation We11s

The use of ground water for irrigation increased in the Albin area subsequent to the development of center-pivot sprinkler systems in the 1960 's. The first irrigation well (17-60-29cbd) in the Albin area that was used with a center-pivot sprinkler system was drilled in 1968 . The increase in the number of completed irrigation wells (wells drilled and equipped with pump and power) is shown in the following table:

\begin{tabular}{lcc} 
Year & $\begin{array}{c}\text { No. of completed } \\
\text { irrigation wells }\end{array}$ & $\begin{array}{c}\text { Cumulative } \\
\text { total }\end{array}$ \\
\cline { 2 - 3 } 1945 & 1 & 1 \\
1962 & 1 & 2 \\
1968 & 1 & 3 \\
1969 & 2 & 5 \\
1970 & 7 & 12 \\
1971 & 8 & 20 \\
1972 & 6 & 26 \\
1973 & 7 & 33 \\
1974 & 7 & 36
\end{tabular}

\section{1/ Data obtained from records of the Wyoming State Engineer's office.}

Most of the irrigation wells in the northern channel deposits yield from $1,000 \mathrm{gal} / \mathrm{min}(63 \mathrm{l} / \mathrm{s})$ to more than $2,000 \mathrm{gal} / \mathrm{min}(126 \mathrm{l} / \mathrm{s})$. The irrigation wells in the central channel deposits yield 500 to 1,600 gal/min (32 to $100 \mathrm{1} / \mathrm{s}$ ). Three irrigation wells north and northeast of Albin yield from 100 to $600 \mathrm{gal} / \mathrm{min}$ ( 6.3 to $38 \mathrm{l} / \mathrm{s})$. The irrigation wells in Rs. 62 and $63 \mathrm{~W}$. yield from about 400 to 1,000 gal/min (25 to $63 \mathrm{l} / \mathrm{s})$. Most irrigation-we11 systems are designed to pump about 800 to $1,000 \mathrm{gal} / \mathrm{min}$ (50 to $63 \mathrm{l} / \mathrm{s}$ ) through the center-pivot sprinkler systems, although many wells could yield more water than is pumped. One exception is wel1 16-60-3bad, which the owner reported yields 2,000 gal/min (126 1/s) and operates two center-pivot sprinkler systems at the same time. The discharges listed in the yield data in table 1 are the measured or estimated discharges for each well. 
Estimated monthly ground-water pumpage for irrigation in 1974 was more than 150 times that of 1968 ( $f$ ig. 6): Most of the well discharges used in the pumpage estimate were measured by personnel of the U.S. Geological Survey, the Wyoming State Department of Economic Planning and Development, and the Wyoming State Engineer's office. Some well discharges used were measured by well drillers. Of a total of 34 irrigation wells that were pumped during 1974, 24 well discharges were measured and 10 well discharges were estimated based on sprinkler-system design and operating pressures. The power consumption (kilowatt hours of power used to pump an acre-foot of water) was calculated using well discharge and the power input for each of the 22 wells pumped using electric power. Electric-power records were obtained from the Rural Electric Association in Pine Bluffs, Wyo. Monthly ground-water pumpage from the 22 wells was estimated by dividing the power consumption into the total kilowatt hours used per month.

of the 34 irrigation wells in the Albin area, 12 were pumped during 1974 using diesel engines equipped with hour meters. The total number of hours the diesel engines operated during 1974 was determined from the difference between hour-meter readings made before and after the irrigation season. These total hours of engine operation were then divided into monthly-hour estimates on the basis of information from owners and a comparison with monthly operation of wells using electric power and irrigating similar crops. The monthly-hour estimates multiplied by well discharges gave the estimated monthly ground-water pumpage from wells using diesel power.

The annual increase in ground-water pumpage from 1968 through 1973 is mostly a result of new irrigation wells being put into use. During 1974, the annual number of newly completed irrigation wells decreased, but the pumpage greatly increased, mostly because of a lack of adequate precipitation. Total annual precipitation for 1974 [12.21 in (310 mm)] was the second lowest amount recorded at Albin since the period of record began in 1941 .

\section{We11 Interference}

In the Albin area, noticeable well interference has not occurred because most wells are spaced about half a mile $(0.8 \mathrm{~km})$ apart due to the use of center-pivot sprinkler systems. Well interference occurs when irrigation wells are close enough to each other that their cones of depression overlap. When this happens, the supply of ground water to each well is diminished, which results in greater drawdowns in each well than if only one well is pumped. 


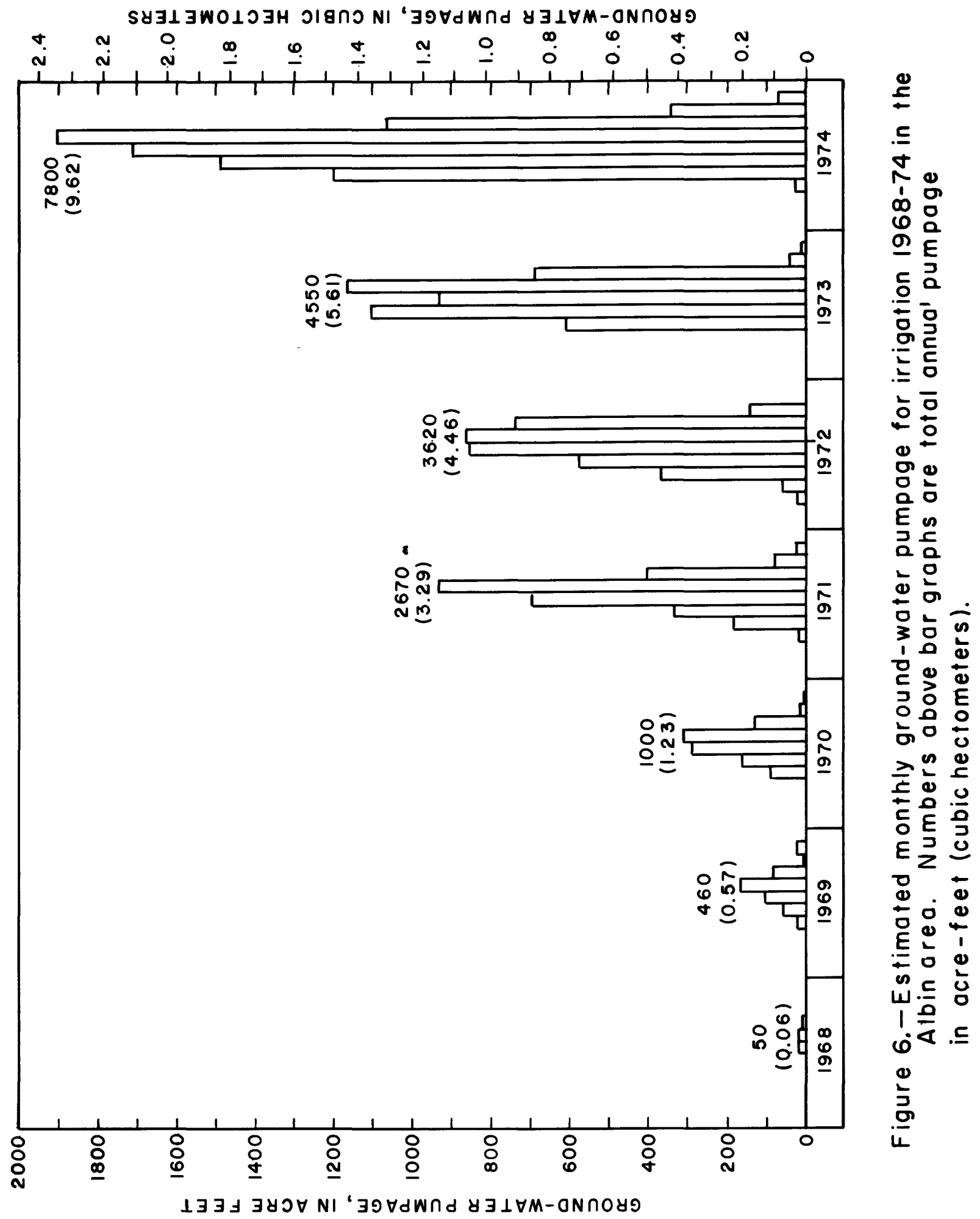


Some well interference could exist between well $17-60-29 \mathrm{cbd}$ and well 17-60-30dad, which are about $950 \mathrm{ft}(290 \mathrm{~m})$ apart. To illustrate possible well interference, assume the aquifer to be homogenous and isotropic with a transmissivity of $53,500\left(\mathrm{ft}^{3} / \mathrm{d}\right) / \mathrm{ft}\left[5,000\left(\mathrm{~m}^{3} / \mathrm{d}\right) / \mathrm{m}\right]$ and a storage coefficient of 0.20 in the vicinity of two wells $1,000 \mathrm{ft}$ $(304.8 \mathrm{~m})$ apart. The time necessary for the cone of depression of each well to reach the half-way point between the wells can be calculated using the Theis (1935) nonequilibrium formula. If both wells pump about $800 \mathrm{gal} / \mathrm{min}(50 \mathrm{l} / \mathrm{s})$ continuously, their cones of depression will meet after about 2.5 hours. After about 30 days of continuous pumping, a $2 \mathrm{ft}(0.6 \mathrm{~m})$ water-level decline will result midway between the two pumping wells.

\section{Irrigated Acreage}

At the end of 1974 , about 6,980 acres $(2,820$ hectares) were being irrigated in the Albin area (fig. 5). Irrigated acreage was calculated from adjudication maps on file at the Wyoming State Engineer's office that show the surveyed location of individual wells and the surveyed acreages being irrigated by those wells.

Most of the irrigated acreage in the Albin area is irrigated using center-pivot sprinkler systems; each system irrigates from about 110 to 160 acres ( 44.5 to 64.8 hectares). The center-pivot sprinklers have sprinkler nozzles spaced along pipe elevated above the ground by several towers, each with two wheels. The system is self propelled around a pivot in the center of the field. Smaller acreages from about 5 to 120 acres (2.0 to 48.6 hectares) in the Albin area are irrigated using either solid set or lateral wheel roll sprinkler systems. The solid set sprinklers have sprinkler nozzles spaced along irrigation pipe that lays on the ground and is manually moved from one location in the field to another. Lateral wheel-roll sprinkler systems have sprinkler nozzles spaced along pipe that is supported above the ground on wheels and is self propelled across a field.

Irrigated acreage can be increased without an increase in the number of irrigation wells being pumped. A common practice is to have another pivot point in an adjacent quarter section and to move the center-pivot sprinkler from one pivot point to another. One well then can be used to irrigate most of two quarter sections using one center-pivot sprinkler. This method is used in sec. 3 and sec. 27, T. 16 N., R. 60 W., sec. 29, T. 17 N., R. 60 W., sec. 31 , T. 17 N., R. 62 W., and sec. 34, T. 18 N., R. 60 W. (fig. 5). Another method used to increase acreage irrigated by the same well or wells.is to install an additional center-pivot sprinkler. In 1973 alone, four additional center-pivot sprinklers were installed to operate with existing irrigation wells. 
The Water Table

\section{Configuration}

Water-table contours depict the general configuration of the water table, somewhat as topographic contour lines illustrate the shape of the land surface. The water table is neither level nor uniform but slopes irregularly. The general direction of ground-water movement is at right angles to the contour lines, in the direction of greatest slope, or hydraulic gradient, of the water table. The rate of ground-water movement is directly proportional to the hydraulic gradient, the cross-sectional area through which the water moves, and the hydraulic conductivity of the water-bearing material.

One continuous water-table was contoured in the Albin area on the assumption that there is hydraulic interconnection between the Arikaree and Ogallala Formations. The water-table contours (fig. 7) indicate that ground water in the Albin area generally moves eastward. The maximum hydraulic gradient is nearly $90 \mathrm{ft} / \mathrm{mi}(20 \mathrm{~m} / \mathrm{km})$ in the southeastern part, and the minimum is about $5 \mathrm{ft} / \mathrm{mi}(0.9 \mathrm{~m} / \mathrm{km})$ in the vicinity of Albin. For most of the area the gradient averages about $20 \mathrm{ft} / \mathrm{mi}$ $(4 \mathrm{~m} / \mathrm{km})$. Wells in Nebraska provide control data for water-table contours on the eastern edge of the Albin area.

The shape and slope (hydraulic gradient) of the water table in the Albin area is primarily a result of three factors: 1) The shape and slope of the underlying bedrock surface (top of the Brule Formation), 2) local differences in the vertical and horizontal hydraulic conductivity of the water-bearing materials, and 3) discharge from the aquifer. Recharge to the aquifer can influence the shape and slope of the water table. However, depths to water in the Albin area are great enough that effects of recharge on the shape and slope of the water table are subdued.

The spacing of water-table contours are an indication of relative transmissivity. At places where no irregularities of the bedrock surface are present, closely spaced contours on the water table commonly indicate areas that are underlain by water-bearing beds of low transmissivity; conversely, widely spaced contours may indicate areas that are underlain by beds of greater transmissivity. However, this is not the only criterion that should be considered. 
North and east of Albin the water-table contours are widely spaced, indicating a low hydraulic gradient and implying a high transmissivity for the aquifer (Arikaree Formation). However, results of test drilling in this area indicate a low hydraulic conductivity and decreased saturated thickness for the Arikaree. Near Albin, some of the ground water from the west is diverted from its eastward movement toward the highly permeable channel deposits to the southeast. Thus, a low hydraulic gradient in the area north and east of Albin was caused by a combination of low hydraulic conductivity, decreased saturated thickness, and less ground water moving through the area. Because of these various factors affecting water-table contours, the interpretation of aquifer characteristics from a water-table contour map should be done cautiously along with all available information.

The water-table contours in the eastern part of the Albin area show a series of ridges and troughs from north to south (fig. 7). The ridges, or ground-water divides, are similar to topographic divides between two drainage basins. Ground water does not cross these divides. Discharge and recharge influence ground-water divides and this can shift their locations. The location of ground-water divides shown in T. $16 \mathrm{~N}$., R. $60 \mathrm{~W}$. correspond to topographic highs because the topographic highs reflect bedrock highs. The ground-water divide east of Albin is caused by a bedrock high, as indicated by a driller's $10 \mathrm{~g}$ of wel1 17-60-22dcd. Ground-water flow from the west splits as it approaches this divide and flows to the northeast and to the southeast. The troughs in the water table southeast of Albin show that ground water flows into the Ogallalafilled channels in the Arikaree and Brule Formations (fig. 3). Because the water table was measured in September, a water-table depression caused by pumping may have made the water-table troughs more pronounced, especially in the northern channel deposits. Before pumping began, the water-table troughs in the channels were probably present and groundwater moved into these channels though at a smaller rate. These thick, permeable channel deposits probably serve as natural discharge channels for the aquifer system.

In the western part of the Albin area, a trough in the water table is located mostly between two irrigation wells and extends northeast from about the southeast corner of T. $17 \mathrm{~N}$., R. $63 \mathrm{~W}$. to about the NE corner of sec. 28, T. $17 \mathrm{~N}$, , R. $62 \mathrm{~W}$. This trough is an area of decline caused by pumping during the irrigation season and is probably not permanent.

\section{Fluctuation}

The water table fluctuates in response to changes in storage of the aquifer. When recharge exceeds discharge, ground-water storage is increased and the water table rises. Conversely, when discharge exceeds recharge, ground-water storage decreases and the water table declines. To define fluctuations of the water table in the Albin area, water levels were measured monthly in 18 wells and continuously by a graphic water-stage recorder in well 16-60-6bba. 
The hydrograph for well 17-60-30dad, an irrigation well located south of Albin in the upper reaches of the northern Ogallala channel deposits, shows the water-level fluctuation in a pumped well (fig. 8). The record indicates an annual decline in the water table at this location. The annual decline during 1974 is larger than in previous years primarily because of an increase in pumping from these channel deposits of about 74 percent in 1974 compared with pumping in 1973, and partly because of a decrease in precipitation during 1974 .

We11 17-60-34cbb, southeast of Albin, is downgradient from seven of the nine irrigation wells pumping from the northern Ogallala channel deposits. The hydrograph for this well (fig. 8) shows a water-table decline that probably resulted from ground-water withdrawals upgradient. The water level in well $17-60-34 \mathrm{cbb}$ was about $7 \mathrm{ft}(2 \mathrm{~m})$ lower in September 1974 than in September 1964 before irrigation development. This decline probably began during or after the 1971 irrigation season when ground-water withdrawals increased considerably over previous years (fig. 6). About $4 \mathrm{ft}(1 \mathrm{~m})$ of decline can be attributed to increased pumpage during 1974. Pumpage of the irrigation wells in this channel deposit southeast of Albin increased 55 percent in 1974 as compared to 1973.

Well 16-60-6bba, southwest of Albin, is along the northern edge of the central channel deposits and east of most of the irrigation wells withdrawing water from these channel deposits. This observation well is equipped with a graphic water-stage recorder. The hydrograph shown in figure 8 was plotted by using the highest water level on the first and fifteenth of each month. The slight decline of the water level in this well is probably the result of ground-water pumpage upgradient.

At well 16-61-14bbc, near the edge of the central channel deposits southwest of Albin, water-level measurements made in September 1964 before ground-water development were about $4 \mathrm{ft}(1 \mathrm{~m})$ higher than ones made in September 1974.

Water-level declines in the northern and part of the central channel deposits between the spring of 1972 and the spring of 1975 are given in the following table:

\begin{tabular}{llc} 
We11 number & Channel deposit location & Water-level decline (ft) \\
\cline { 2 - 3 } $17-60-28 c c c$ & northern & 6 \\
$17-60-30$ dad & northern & 3 \\
$17-60-33 b c c$ & northern & 6 \\
$17-60-34 \mathrm{cbb}$ & northern & 5 \\
$16-61-15 \mathrm{bbd}$ & central & 3
\end{tabular}




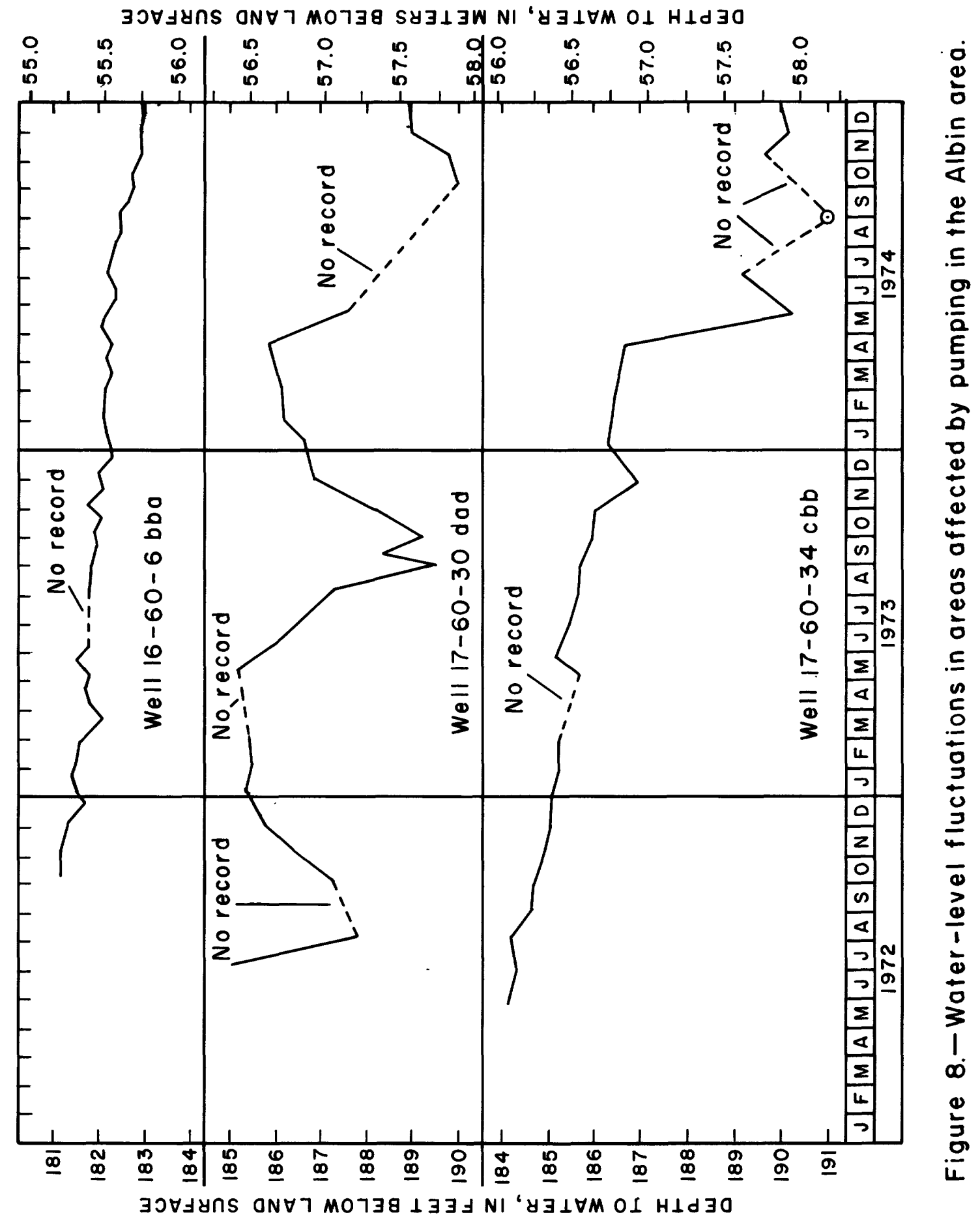


Because of a need for better water-level data in the northern and central channel deposits, an observation well equipped with a water-level recorder was installed during May 1975 by the Wyoming State Engineer in each of the channel deposits. Well 17-60-33cbb was drilled south of Albin in the northern channel deposits, and well 16-60-7bbb was drilled southwest of Albin in the central channel deposits. Digital water-stage recorders were installed on each well to record the water-level changes.

In the west half of the Albin area, no significant water-level changes have occurred except for seasonal water-level fluctuations near irrigation wells.

\section{Chemical Quality of the Ground Water}

Chemical-quality data for ground water in the Albin area are given in table 2. These samples were collected in order to determine the general quality of the ground water in the Albin area and to serve as background data for possible future changes in ground-water quality. Analyses of some ground-water samples collected before 1972 are included to supplement the data.

No changes in ground-water quality are evident from a comparison of data collected before irrigation began with data collected in 1972 . To determine any future changes in ground-water quality, the same wells should again be sampled. In the Albin area, because the depth to water in most of the irrigated areas is greater than $150 \mathrm{ft}(46 \mathrm{~m})$, in the Albin area, changes in ground-water quality due to irrigation are not expected in the near future. For a discussion of the chemical quality of water see Lowry and Crist (1967, p. 50-57).

\section{$\underline{\text { Summary and Conclusions }}$}

Irrigation wells in the Albin area are developed in either the Arikaree or Ogallala Formations, or in both. The chances of getting a well that yields $500 \mathrm{gal} / \mathrm{min}(32 \mathrm{1} / \mathrm{s})$ or more from the Arikaree are improved if the formation is fully penetrated and the well is carefully developed. Because of the fine grained, loosely to moderately cemented sandstone of the Arikaree, careful well development is necessary to stabilize the sand around the well so that the well will yield the maximum amount of water that is free of sand. 


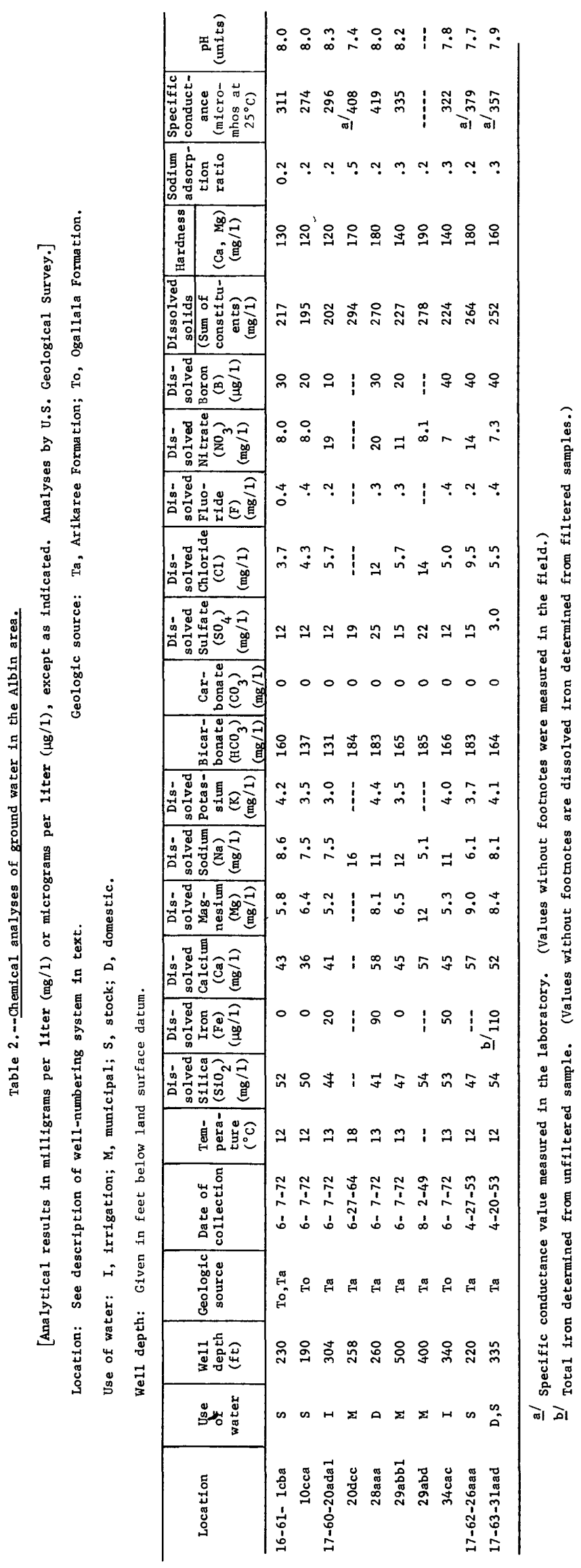


Most of the irrigation wells in the Albin area are in coarse-grained deposits of the Ogallala Formation that were deposited in channels eroded in the Brule and the Arikaree Formations. These channel deposits are heterogeneous and at places are extremely permeable. The transmissivity of $93,600\left(\mathrm{ft}^{3} / \mathrm{d}\right) / \mathrm{ft}\left[8,700\left(\mathrm{~m}^{3} / \mathrm{d}\right) / \mathrm{m}\right]$ obtained from an aquifer test at we11 $17-60-33 \mathrm{dbbl}$ is probably higher than the average value for all the Ogallala channel deposits. However, transmissivities of at least 15,000 $\left(\mathrm{ft}^{3} / \mathrm{d}\right) / \mathrm{ft}\left[1,400\left(\mathrm{~m}^{3} / \mathrm{d}\right) / \mathrm{m}\right]$ can probably be expected for most of the Ogallala channel deposits with a saturated thickness of at least $100 \mathrm{ft}$ $(30 \mathrm{~m})$. Test drilling could be used to locate sites for irrigation wells in the Arikaree or the Ogallala Formations.

Water-table declines have occurred principally in the channel deposits in the Albin area. In the northern channel deposits southeast of Albin, the water table was about $7 \mathrm{ft}(2 \mathrm{~m})$ lower in September 1974 than in September 1964 before irrigation development. Most of the water-table decline, about $4 \mathrm{ft}(1 \mathrm{~m})$, occurred during 1974 when pumpage increased. In the central channel deposits southwest of Albin, the water table was about $4 \mathrm{ft}$ ( $1 \mathrm{~m}$ ) lower in September 1974 than in September 1964. Because ground water is being pumped from storage in the channel deposits, causing water-table declines, continued monitoring of water levels is advisable, using the established observation well network.

No changes in ground-water quality are evident from a comparison of data collected before irrigation began with those collected in 1972 . Changes in ground-water quality due to irrigation are not expected in the near future. However, to best determine any future changes in ground-water quality, the wells sampled in 1972 should be resampled periodically.

\section{GEOHYDROLOGY OF THE LA GRANGE AREA}

Rocks exposed in the La Grange area (fig. 9) are as follows: The Lance Formation of Late Cretaceous age, the Chadron and Brule Formations of the White River Group of 0ligocene age, the Arikaree Formation of early Miocene age, the terrace deposits of Pleistocene age, and the alluvium of Pleistocene and Holocene age.

The Lance, Chadron, and Arikaree Formations are not important to this study because they are not significant aquifers in the La Grange area. The Arikaree yields water only to stock and domestic wells where the Arikaree forms the upper part of Sixtysix Mountain and where it is exposed along the southern boundary of the La Grange area. 
The terrace deposits east and southeast of La Grange are virtually dry (located above the water table) but are of interest because they represent deposition by Horse Creek and Bear Creek along their former stream drainages. Before the Goshen Hole lowland was eroded, Bear Creek flowed into Horse Creek, and Horse Creek flowed eastward into Pumpkin Creek in Nebraska. During this time the terrace materials were deposited. As the erosion of Goshen Hole continued southward, the headwaters of streams receded southward also until they intercepted, or captured, Bear Creek and then Horse Creek and diverted their flow into Goshen Hole. The former courses of Bear Creek and Horse Creek can be approximated by extending the stream courses of each creek as they are now shown in figure 1 eastward from the point where the creeks bend north. As the erosional processes continued in Goshen Hole, the terrace deposits were drained. Although the terrace deposits are dry, water from precipitation moving through their coarse materials provides for a larger amount of recharge to the Brule than is available in areas where the Brule is not overlain by permeable deposits.

All the irrigation wells in the La Grange area obtain water from either the Brule Formation or the alluvium, or both. Thus, only the aquifer characteristics of the Brule and the alluvium will be presented.

\section{Brule Formation}

\section{Distribution and Character}

The Brule Formation of the White River Group is exposed along parts of the valleys of Horse Creek and Bear Creek in the La Grange area. The most prominent and extensive exposures of the Brule are at the bases and in the lower slopes of the escarpments along the southern boundary of Goshen Hole and Sixtysix Mountain northeast of La Grange.

In the La Grange area, Sixtysix Mountain is a conspicuous land form that is a remnant of an upland that extended as a narrow ridge between the North Platte River, about $30 \mathrm{mi}(48 \mathrm{~km})$ north of La Grange, and the former Horse Creek-Pumpkin Creek valley. That part of the Brule Formation exposed along the escarpments of Sixtysix Mountain, beneath the capping Arikaree Formation, represents the upper part of the Brule and is a relatively uniform deposit of moderately well-consolidated silt and very fine grained sand. 
The part of the Brule Formation from which most of the irrigation wells in the La Grange area are getting their water is typically a massive, very light pinkish-gray or pinkish-brown, moderately hard, brittle, argillaceous siltstone. No particle-size analyses were made of samples of the Brule from the La Grange area. However, Denson and Bergendahl (1961) made particle-size analyses of about 100 samples from 10 measured sections of their White River Formation in southeastern Wyoming and adjacent areas of Nebraska and Colorado and stated (1961, p. C170), "In general, these rocks consist of 65 to 85 percent silt and 5 to 25 percent very fine grained sand embedded in a matrix of clay-size particles," indicating that "these rocks are remarkably uniform in grain size over wide areas." Denson and Bergendahl (1961) considered the White River of formation rank and did not differentiate the rocks into the Chadron and Brule Formations of the White River Group. However, judging from the locations where their samples were collected, probably most of their samples were representative of the upper unit of their White River Formation, or Brule Formation in this report. Rapp and others (1957, p. 32-33) made particle-size analyses of six samples of the Brule from Goshen County. In these samples, the percentage of silt ranged from 53.8 to 77.6 and averaged about 70 . The percentage of clay ranged from 14.1 to 23.8. Both the analyses of Denson and Bergendahl and those of Rapp and others indicate the Brule is composed mainly of silt with varying amounts of clay and sand. Thus, the term "Brule Clay" often used by some drillers and others is generally inaccurate; the Brule locally may be sandy or clayey but is basically a siltstone.

\section{Secondary Permeability and Porosity}

Successful irrigation wells drilled in the Brule Formation must penetrate zones of secondary permeability because the Brule, composed mostly of silt-sized particles, otherwise is generally impermeable and yields little water to wells. The permeability of a porous material is its capacity for transmitting a fluid. The degree of permeability depends upon the size, shape, and extent of the interconnection of pore space. Secondary permeability generally results from fracturing or chemical solution after deposition form interconnected voids in the formation. 
Early investigations attributed the secondary permeability in the Brule Formation to fissures, joints, and fractures. Lowry (1966) thought a better explanation of the locally high secondary permeability of the Brule Formation was a geomorphic agent known as piping. Piping is the process by which subterranean channels or pipes are developed by surface erosion of relatively insoluble, incoherent clastic rocks such as the Brule Formation. Parker (1963) listed the following basic essentials for the formation of pipes: 1) Water enough to saturate some part of the soil or bedrock above base level; 2) hydraulic head to move the water through a subterranean route; 3) presence of a permeable, erodible soil or bedrock above base level; and 4) an outlet for flow. Parker stated that in practically all piped soils and rocks a swelling clay, montmorillonite, was usually present. The Brule contains varying amounts of montmorillonitic clay. The swelling clays, when wet, are vulnerable to erosion by moving water because they become highly dispersed, slick, plastic, and noncohesive. Thus, even in slowly moving water such as that which seeps through fractures in rocks, wet clay platelets and silt-size fragments will wash away in suspension (Parker, 1963). It is possible that before deposition of the alluvium in the La Grange area conditions were favorable for the development of pipes in the Brule.

Although not given as total explanation for secondary permeability of the Brule Formation, solution activity was mentioned by Crist and Borchert (1972, p. 21) to be an important factor. Carbonate and bicarbonate compounds are the most soluble minerals in the Brule. Nineteen samples of Brule were collected from test holes and analyzed for carbonate content. The analytical procedure used by Crist and Borchert (1972) was such that primarily carbonates and bicarbonates were dissolved and measured as part of the carbonate content. The range in carbonate content (percent $\mathrm{CO}_{3}$ equivalents by weight) was from 1.80 to 13.70 percent. The range of values given is probably realistic for the Brule Formation. Denson and Bergendah1 (1961, p. C170) showed average percentage of calcium carbonate for ten samples to range from 20 to 31 percent. It is not known if Denson and Bergendahl considered all acidsoluble materials in each sample as calcium carbonate. The presence of soluble minerals in the Brule indicates that development of secondary permeability in the Brule could have been, at least in part, assisted by solution activity.

A downhole television camera was used to study the secondary permeability of the Brule Formation in southeastern Wyoming. The Brule was examined in 10 wells in southeastern Laramie County (Crist and Borchert, 1972) and in well 20-61-35aab in the La Grange area. All these wells were cased only through the overlying unconsolidated material and completed as open holes in the Brule Formation. Openings of various sizes and shapes were revealed; some resembled tubes or caverns (Crist and Borchert, 1972, p. 20). Only a few of the openings appeared to be associated with fracturing. Openings such as seen in the other wells were not revealed by the television camera in well 20-61-35aab in the La Grange area. 
Openings in the Brule were seen by the television camera as previously described and by a borehole televiewer as described in the following paragraphs. These openings should be described as secondary porosity because it is not known whether the openings are interconnected. The secondary porosity of a formation is its property of containing interstices or voids which developed after deposition. Zones of secondary porosity or actually secondary permeability, which yield large amounts of water to wells in the La Grange area, are described by drillers as zones of broken hardpan, creviced hardpan, and broken Brule. Drillers report angular chunks of Brule coming from these zones. Drillers have encountered these zones in several wells from 40 to $60 \mathrm{ft}$ (12 to $18 \mathrm{~m}$ ) and from 90 to $110 \mathrm{ft}$ ( 27 to $34 \mathrm{~m})$.

During this study, W. S. Keys, Chief of Borehole Geophysics Research project, U.S. Geological Survey, tested an acoustic borehole televiewer in wells 19-61-13baa and 20-61-35aab. This logging tool takes an acoustic picture of the borehole wall as it is continuously moved up the borehole. The resulting $10 \mathrm{~g}$ or picture is a reproduction of the entire 360 degrees of the borehole wall as if it were split vertically at magnetic north and laid flat.

A photograph of a portion of the televiewer $\log$ from 38 to $50 \mathrm{ft}$ (12 to $15 \mathrm{~m}$ ) for well 19-61-13baa is shown in figure 10. Interpretations of the following features on the televiewer $\log$ have been made by Keys (written commun., 1974). One feature, the diagonal pattern, shown from 38 to $43 \mathrm{ft}(12$ to $13 \mathrm{~m}$ ) is present along the total depth of the borehole except for the section from 43 to about $49 \mathrm{ft}$ (13 to $15 \mathrm{~m}$ ). This pattern is probably due to "rifling" caused by slow turning of the drill bit as it was withdrawn from the hole. A second feature is the vertically aligned dark or continuous dark bands shown on figure 10 from about 40 to $44 \mathrm{ft}(12$ to $13 \mathrm{~m})$ and throughout most of the televiewer $\log$. This feature is due to the eccentricity of the borehole.

Features interpreted as secondary porosity in figure 10 are at depths of $40.2,43.6,46.4$, and $49.3 \mathrm{ft}(12.3,13.3,14.1$, and $15.0 \mathrm{~m})$. At these depths the secondary porosity appears to be fairly continuous all around the borehole and to have developed along horizontal bedding planes. Other secondary porosity features similar to those shown in figure 10 were seen on the televiewer $\log$ at depths of about 65 and 81 ft $(20$ and $25 \mathrm{~m})$. Other features interpreted as secondary porosity from the televiewer $\log$ were at depths of about 61,69 , and $71.5 \mathrm{ft}(19,21$, and $21.8 \mathrm{~m})$. At about $43.5 \mathrm{ft}(13.3 \mathrm{~m})$ and $80 \mathrm{ft}(24 \mathrm{~m})$ there appears to be large irregular cavities located mostly in the southeastern to southwestern part of the borehole. Because there are dark areas due to the eccentricity of the hole near the cavities, the interpretation of the size of the cavities or even the number of cavities at $43.5 \mathrm{ft}$ $(13.3 \mathrm{~m})$ is doubtful. The writer did not interpret any features in we11 19-61-13baa as fractures. 


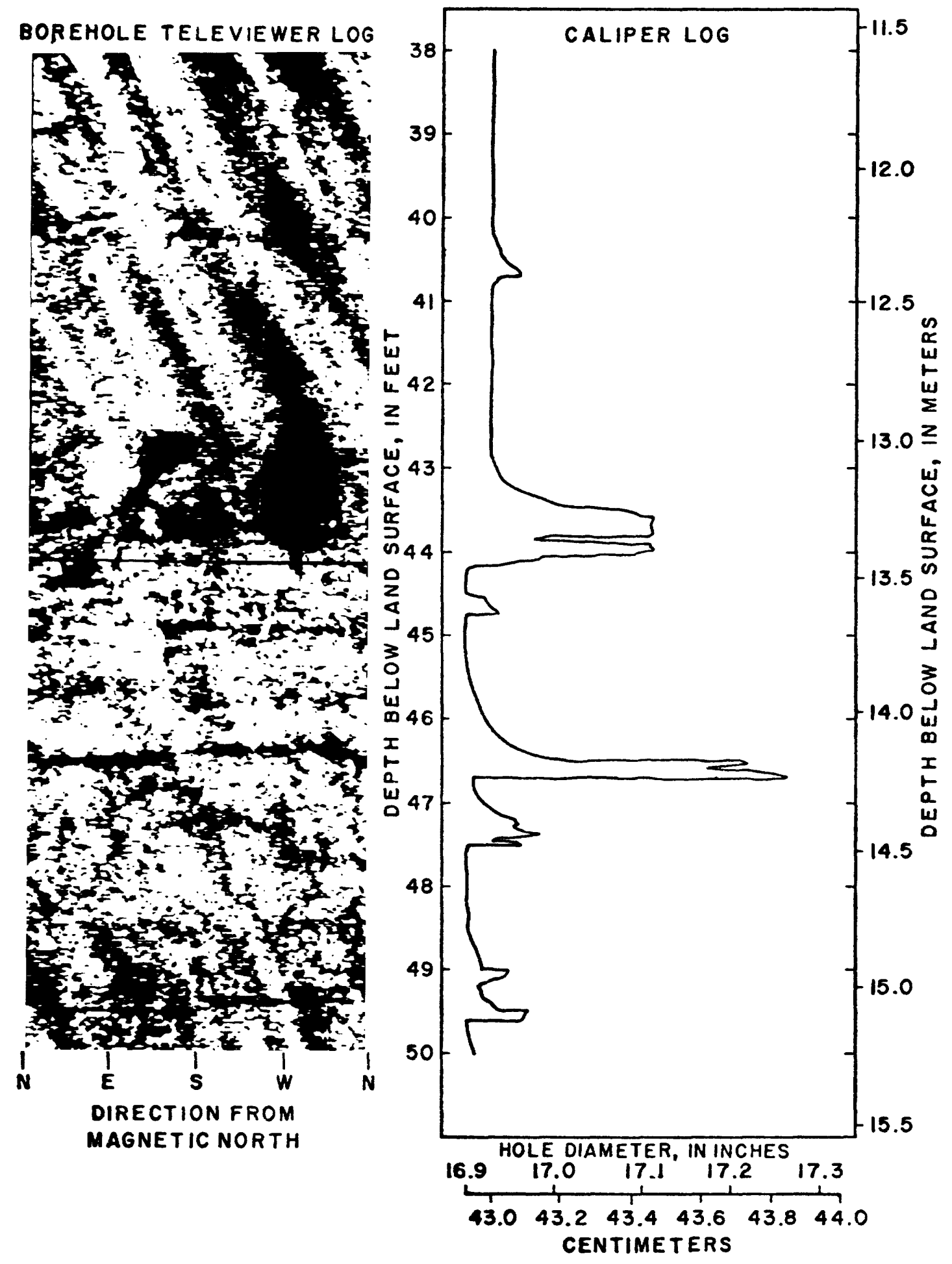

Figure 10.- Photograph of portion of Borehole Televiewer log for well $19-61-13$ boo showing secondory porosity in the. Brule Formation and coliper log for same interval. Photograph was provided by W. S. Keys, U. S. Geological Survey. 
The caliper log shown on figures 10 and 11 is a record of the average diameter of well 19-61-13baa. Increases in average diameter of the well are shown as deflections to the right. The caliper log confirms the presence of openings shown on the televiewer log in the interval from 40 to $50 \mathrm{ft}(12$ to $15 \mathrm{~m})$ and at depths of 65 and $81 \mathrm{ft}(20$ and $25 \mathrm{~m})$. Because the caliper tool has only three arms following the wall of the borehole, it is possible that some cavities may have been spanned by the arms and not logged. The magnitude of the average hole diameter increase shown on the caliper log does not show the depth of the cavities, because the caliper arms can enter only a short distance into small openings.

Horizontal features interpreted as secondary porosity were seen on the televiewer $\log$ of well 20-61-35aab at depths of 27, 58, 63, and $67 \mathrm{ft}(8,17,19$, and $20 \mathrm{~m})$. These features were not as obvious as those on the televiewer $\log$ for well 19-61-13baa. The televiewer log for well 20-61-35aab only vaguely showed diagonal patterns at depths of 38 to $39 \mathrm{ft}$ (about $12 \mathrm{~m}$ ), 43.5 to $45.5 \mathrm{ft}(13.3$ to $13.9 \mathrm{~m}$ ), and 47 to $49 \mathrm{ft}$ (14 to $15 \mathrm{~m})$. It is not apparent why this diagonal pattern shows up throughout most of well 19-61-13baa and only in a few short intervals in well 20-61-35aab. It may be an indication of slight differences in lithology or a difference in drilling technique.

Several geophysical logs, other than the Borehole Televiewer logs and the caliper logs, were run in wells 19-61-13baa and 20-61-35aab. The primary purpose of running geophysical logs in these wells was to determine if the logs would record secondary porosity in the Brule Formation. Zones of increased average hole diameter were located by caliper logs, and the televiewer log or television pictures were used to interpret whether these zones are characterized by secondary porosity. At known intervals of secondary porosity, an evaluation was made of the response of the geophysical logs. According to W. S. Keys (written commun., 1974), "it should be recognized that the response of most geophysical logging devices is not unique and core samples are necessary to guide $\mathrm{log}$ interpretation in each new area. The effect of hole diameter on the response of nondecentralized probes may be extreme in wells as large as the ones logged for this study. The gamma, gammagamma, and neutron logs will all show this kind of error." Before the televiewer logs were run, caliper, natural-gamma, and gamma-gamma logs were run in well 19-16-13baa. 


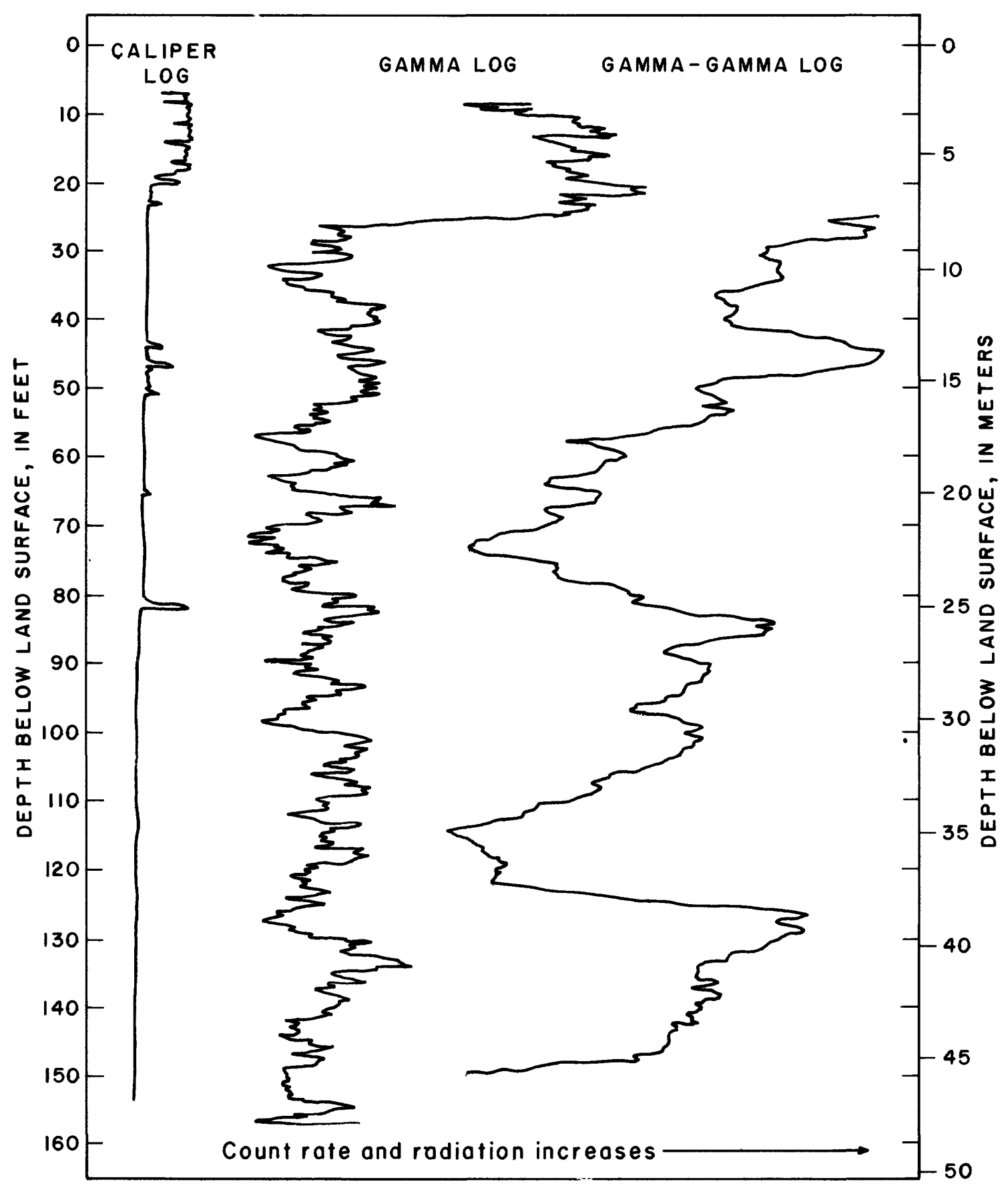

Figure II.-Caliper log, gamma log, and gamma-gamma log for well 19-61-13 boa. 
The natura1-gamma $10 \mathrm{~g}$ of ten indicates clay content of sediments, because radioactive elements are generally concentrated in clays. Increased natural gamma radiation can also be caused by the presence of volcanic ash. The Brule Formation is basically a siltstone with varying amounts of montmorillonitic clay, very fine sand, and fine volcanic ash (Denson and Bergendah1, 1961, p. C170). In we11 19-61-13baa, the interval from 38 to $50 \mathrm{ft}$ ( 12 to $15 \mathrm{~m}$ ) ( $\mathrm{fig}$. 10) has the greatest concentration of secondary porosity features in the hole. About half [43-49 ft $(13-15 \mathrm{~m})]$ of this interval does not show the diagonal pattern seen in the rest of the hole, which might infer a different lithology. The interval from 38 to $50 \mathrm{ft}$ (12 to $15 \mathrm{~m}$ ) appears fairly uniform on the gamma $10 \mathrm{~g}$ and has a higher gamma count rate than the average for the hole (fig. 11). This interval could be interpreted as having a higher than average clay content for the hole. A higher clay content in the interval 38 to $50 \mathrm{ft}(12$ to $15 \mathrm{~m}$ ) is confirmed by the following driller's log for well 19-61-13baa:

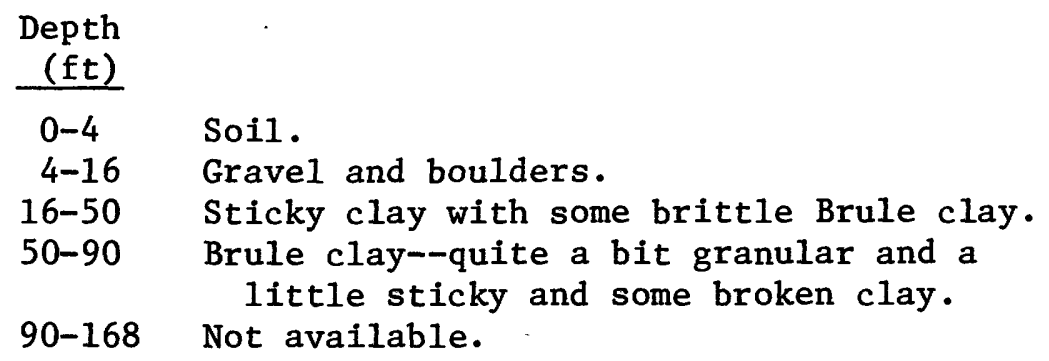

Peaks on the gamma $\log$ at 61,67 , and $80-83 \mathrm{ft}(19,20$, and 24-25 m) are greater than the average gamma count rate for the total log. These approximately correlate with known depths of secondary porosity. Other peaks in gamma count rate are recorded at depths. greater than $83 \mathrm{ft}(25 \mathrm{~m})$ where no secondary porosity features were interpreted on the televiewer $10 \mathrm{~g}$. The peaks of natural-gamma count rate recorded on the gamma $10 \mathrm{~g}$ could have resulted from concentration of radioactive elements deposited in zones of secondary porosity as a result of solution activity or by concentrations of volcanic ash. Thus, development of secondary porosity could be related to clay or ash beds.

Increased gamma-gamma count rate, from about 42 to $49 \mathrm{ft}$ (13 to $15 \mathrm{~m}$ ) (fig. 11), is probably a result of a combination of higher porosity and greater hole diameter at zones of secondary porosity. The log amplitude recorded for the interval 42 to $49 \mathrm{ft}(13$ to $15 \mathrm{~m})$ on the gamma-gamma log correlates with the secondary porosity on the televiewer $\log$ in the interval 38 to $50 \mathrm{ft}(12$ to $15 \mathrm{~m})$. Correlation between the gamma-gamma $\log$ and secondary porosity features interpreted on the televiewer $\log$ at other depths is not as apparent. Small peaks on the gamma-gamma $\log$ are at about $60,65,69$, and $81 \mathrm{ft}(18,20,21$, and $25 \mathrm{~m}$ ) and at several greater depths. The smaller peaks could be the result of thin zones of relatively high porosity because the response of the gamma-gamma probe is an average of the bulk density over a vertical interval of about $1 \mathrm{ft}(0.3 \mathrm{~m})$. Futhermore, an increase in recorded count rate would probably result if the gamma-gamma probe moved away from the wall of the hole (W. S. Keys, written commun., 1974). 
In well 20-61-35aab, the following geophysical logs were run: Caliper, natural gamma, gamma-gamma, spontaneous potential (SP), single point resistance, neutron, temperature, and impeller flowmeter logs. The caliper log did not show any changes in average hole diameter. At various depths in the hole, the gamma, SP, and neutron logs seem to indicate similar lithology. Some features on the televiewer log appear to be similar to those in well 19-61-13baa, indicating secondary porosity in this well. W. S. Keys (written commun., 1974) noted that the gammagamma $\log$ and the neutron log show anomalies that correlate with some of the secondary porosity features shown on the televiewer $10 \mathrm{~g}$ and some that do not correlate. It is possible that the secondary porosity in this hole is more randomly distributed rather than horizontally distributed along bedding planes as indicated in well 19-61-13baa. The variable background on the televiewer log, due to roughness of the wall of the hole, makes a random pattern of secondary porosity impossible to see. The temperature $\mathrm{log}$ showed no change in temperature of the water in the hole, and the flowmeter did not detect any flow in the hole.

Secondary porosity in the Brule Formation might be determined better if in addition to the logs run in well 19-61-13baa, SP, resistance and neutron logs were run. A more reliable response would be provided by logs run with decentralized tools. Along with the geophysical logs, cores taken during drilling of the holes, or sidewall samples from zones of secondary porosity, are necessary to adequately interpret the logs.

\section{Hydraulic Properties}

Aquifer tests were made at wells 19-61-9dbbl and 19-61-1labc to determine the hydraulic properties of the Brule Formation. Data from these aquifer tests were analyzed by the Theis nonequilibrium formula (Theis, 1935) and the Theis recovery formula (Theis, 1935). The values of transmissivity obtained by the two analyses for both aquifer tests compared favorably. The following table lists the average results for the two aquifer tests:

\begin{tabular}{|c|c|c|c|c|c|}
\hline $\begin{array}{l}\text { Location of } \\
\text { pumped well }\end{array}$ & $\begin{array}{l}\text { Location of } \\
\text { observation well } \\
\text { from } \\
\text { pumped wel1 } \\
\text { (ft) }\end{array}$ & $\begin{array}{c}\text { Transmissivity } \\
{\left[\left(\mathrm{ft}^{3} / \mathrm{d}\right) / \mathrm{ft}\right]}\end{array}$ & $\begin{array}{c}\text { Storage } \\
\text { coefficient }\end{array}$ & $\begin{array}{c}\text { Length } \\
\text { of } \\
\text { test } \\
\text { (hrs) }\end{array}$ & $\begin{array}{c}\text { Date } \\
\text { test } \\
\text { started }\end{array}$ \\
\hline \multirow[t]{3}{*}{$19-61-9 \mathrm{dbb} 1$} & --- & 77,100 & --- & 24 & $5-21-73$ \\
\hline & 50 (northwest) & 67,400 & $1.0 \times 10^{-4}$ & & \\
\hline & 800 (west) & 83,800 & $7.0 \times 10^{-4}$ & & \\
\hline $19-61-11 a b c$ & --- & 104,600 & --- & 1.4 & $11-15-72$ \\
\hline
\end{tabular}




\section{$\underline{\text { Alluvium }}$}

\section{Distribution and Character}

The alluvium consists of valley-fill deposits in the vicinity of La Grange and flood-plain deposits extending along most of Horse Creek and its principal tributary, Bear Creek. For the purposes of this report, the valley-fill and flood-plain deposits are mapped together as alluvium (fig. 9) and not considered separately.

The alluvium covers an area near La Grange about $6.1 \mathrm{mi}(9.8 \mathrm{~km})$ wide by $9.8 \mathrm{mi}(16 \mathrm{~km})$ long. It was deposited mostly on the Brule Formation except in the northern part of the area where it overlies the Lance Formation. The alluvium consists mostly of sand and gravel with abundant fragments of pink feldspar, lenses of silt and clay, and siltstone pebbles. The thickness of the alluvium ranges from a few feet at the edge to about $60 \mathrm{ft}(18 \mathrm{~m})$ in the $\mathrm{SW} \frac{1}{4}, \mathrm{sec} .33, \mathrm{~T} .20 \mathrm{~N} ., \mathrm{R}$. $61 \mathrm{~W}$.

The area of greatest saturated thickness of alluvium northwest of La Grange seems to form a basin as contoured on figure 9. Surfaceresistivity soundings provided additional control for determining the thickness of the alluvium in sec. 27 and $34, T .20 \mathrm{~N} ., \mathrm{R} .61 \mathrm{~W}$. The saturated thickness map was constructed by superimposing the contour map of the top of the Brule Formation and the water-table contour map. The control points on figure 9 have been omitted for clarity.

\section{Hydraulic Properties}

Aquifer tests of the alluvium were analyzed by the Theis nonequilibrium formula (Theis, 1935) and Jacob's modified nonequilibrium formula (Jacob, 1950). The results are listed in the following table:

\begin{tabular}{|c|c|c|c|c|c|}
\hline $\begin{array}{l}\text { Location of } \\
\text { pumped wel1 }\end{array}$ & $\begin{array}{l}\text { Location of } \\
\text { observation we11 } \\
\text { from } \\
\text { pumped well } \\
\text { (ft) }\end{array}$ & $\begin{array}{c}\text { Transmissivity } \\
{\left[\left(\mathrm{ft}^{3} / \mathrm{d}\right) / \mathrm{ft}\right]}\end{array}$ & $\begin{array}{c}\text { Storage } \\
\text { coefficient }\end{array}$ & $\begin{array}{c}\text { Length } \\
\text { of } \\
\text { test } \\
\text { (hrs) }\end{array}$ & $\begin{array}{l}\text { Date } \\
\text { test } \\
\text { started }\end{array}$ \\
\hline \multirow[t]{3}{*}{$19-61-4 c d d 4$} & --- & 30,700 & ---- & 30 & $3-12-73$ \\
\hline & 158 (west) & 34,500 & $4.7 \times 10^{-3}$ & & \\
\hline & 288 (west) & 50,200 & $1.9 \times 10^{-2}$ & & \\
\hline $20-61-33 c d d 2$ & ---- & 17,200 & --- & 1.5 & $11-14-72$ \\
\hline
\end{tabular}


Because of a major snowstorm during the aquifer test at well 19-61-4cdd4, recovery data were not obtained for any wells except the observation well equipped with a graphic water-stage recorder. Thus, most of the transmissivities were calculated from analyses of the drawdown only. After about 150 to 200 minutes, the rate of drawdown in the pumped well and in the observation wells increased as a result of the cone of depression reaching the Brule Formation south of the test site. Because the Brule in this area has low permeability, it acts as a hydrologic barrier boundary resulting in change of the relationship between time and rate of drawdown. The approximate location of this boundary was calculated, using image-well theory (Ferris and others, 1962, p. 161-166), to be about $250 \mathrm{ft}(76 \mathrm{~m})$ from the pumped well, which is about the distance to the alluvium-Brule contact.

Determination of the hydraulic properties of the alluvium was based on the early drawdown data before the boundary conditions affected the analysis (Ferris and others, 1962, p. 161). The high transmissivities obtained from this test are representative of the aquifer properties and not of the aquifer conditions that will affect a pumping well. Driller's logs of the pumping well and the two observation wells indicate the alluvium at the test site consists predominantly of gravel, but coarse sand and boulders 8 in $(203 \mathrm{~mm})$ in diameter also were encountered. Althougl the transmissivity is high at this location, the boundary conditions south of this site restrict the expansion of the cone of depression southward, causing the water to move toward the well predominantly from only a portion of the cone of depression and from greater distances. Thus, well yields in this area are less and drawdowns are greater than for a well pumping from an aquifer of great areal extent with the same hydraulic properties as determined for this site. Because of the effects of the boundary, specific capacities should not be estimated from the transmissivities given in the preceding table for well 19-61-4cdd4 and the nearby observation wells.

The storage coefficients computed are much less than the actual specific yield of the aquifer because gravity drainage was not complete at the end of the 30-hour test. Specific yield is the quantity of water that a unit volume of the aquifer will give up when drained by gravity. In a water-table aquifer, specific yield is equal to the storage coefficient.

The transmissivity calculated from the aquifer test at well 20-61-33cdd2 is a reasonable value for the alluvium. Drillers' logs for this well and other wells nearby indicate the alluvium at this location consists predominantly of sand and medium to large gravel with fine sand and boulders also encountered. The transmissivities obtained at well 19-61-4cdd4 and well 20-61-33cdd 2 should be regarded as representative of the alluvium only in the vicinity of the test sites. This is because the saturated thickness and hydraulic conductivity can vary considerably from one site to another. 


\section{Irrigation Development}

The use of surface water for irrigation in the La Grange area dates back to the $1880^{\prime}$ 's and $1890^{\prime}$ 's when territorial water rights were adjudicated by the courts. Surface water in the La Grange area is obtained only by direct diversion from Horse Creek and Bear Creek. All major surface-water diversion rights now in use on Horse Creek and Bear Creek in the La Grange area were filed and adjudicated before 1900 . Alfalfa and native hay were the principal crops irrigated. Horse Creek and Bear Creek are now fully appropriated streams.

Hawk Springs, at the west end of Sixtysix Mountain, was referred to by Adams (1902, p. 27) as "perhaps the largest so-called spring in the Goshen Hole Country." Hawk Springs was located on his geologic map at about 20-61-9dbd and was described as a locality where the ground was seepy, with water rising at a number of places. Adams (1902, p. 28) speculated that Hawk Springs was the discharge point for ground water which flowed in a natural channel in the alluvium. Hawk Springs was inundated in 1908 when Hawk Springs Reservoir was built to furnish water to landowners north of the La Grange area. Most of the water in Hawk Springs Reservoir is surface water diverted from Horse Creek. Since 1966, ground water from wells in secs. 15 and 22, T. 20 N., R. 61 W., has been pumped to supplement the surface-water supply for Hawk Springs Reservoir.

The first irrigation wells were drilled in 1936 in the alluvium. Early irrigation was mostly done by gravity (ditch and row, and flood methods). Before 1962 all the irrigation wells, except three, were located west of Horse Creek. The first center-pivot sprinkler irrigation system was installed in 1962. More than half of the irrigation wells drilled since 1962 are used with center-pivot sprinkler systems. In this section of the La Grange area, the term "irrigation wel1s" refers to the wells that supply water to irrigate lands in the La Grange area. Thus, the Horse Creek Conservation District wells are considered separately because they supply water to Hawk Springs Reservoir for use north of the La Grange area. The following table gives the number of new irrigation wells completed per year and the irrigaton method used. The data in this table were compiled using records at the Wyoming State Engineer's office, information from owners, and field inspections. 
Number of new irrigation

Year wells completed and method of irrigation used a/

Gravity $\quad$ Sprinkler

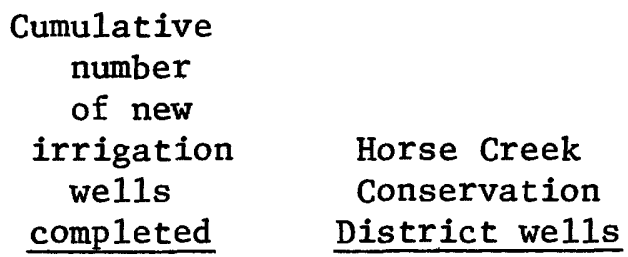

District we11s

\begin{tabular}{|c|c|c|c|c|}
\hline 1936 & 2 & -- & 2 & \\
\hline 1939 & $\underline{\mathrm{b}} / 1$ & -- & 3 & \\
\hline 1941 & 1 & -- & 4 & \\
\hline 1949 & 1 & -- & 5 & \\
\hline 1950 & 3 & -- & 8 & \\
\hline 1955 & 1 & -- & 9 & \\
\hline 1958 & 5 & -- & 14 & \\
\hline 1962 & 1 & 1 & 16 & \\
\hline 1963 & 2 & -- & 18 & \\
\hline 1964 & -- & 3 & 21 & \\
\hline 1965 & 1 & -- & 22 & \\
\hline 1966 & -- & 2 & 24 & 3 \\
\hline 1967 & 1 & 5 & 30 & 2 \\
\hline 1968 & 3 & 2 & 35 & 2 \\
\hline 1969 & -- & 11 & 46 & 2 \\
\hline 1970 & 2 & 9 & 57 & \\
\hline 1971 & 1 & 2 & 60 & \\
\hline 1972 & 1 & -- & 61 & \\
\hline 1973 & -- & 1 & 62 & \\
\hline 1974 & -- & -- & 62 & \\
\hline TOTALS & 26 & 36 & & 9 \\
\hline
\end{tabular}




\section{Surface Water}

Horse Creek has its headwaters in the Laramie Mountains; it is a tributary to the North Platte River about $30 \mathrm{mi}(48 \mathrm{~km})$ north of La Grange. The Horse Creek drainage area is about $680 \mathrm{mi}^{2}\left(1,760 \mathrm{~km}^{2}\right)$. Daily discharge was recorded from November 1, 1915 to April 4, 1920 at a gaging station, Horse Creek at La Grange, located in SW/ $\mathrm{SW}^{\frac{1}{4}} \mathrm{sec} .34$, T. 20 N., R. $61 \mathrm{~W}$. More recently a gaging station, Horse Creek at Wycross Ranch, was operated at 20-61-28bca from October 1965 through December 1973. At this latter gaging station, for the 8-year period of record, the mean daily discharge was $26.5 \mathrm{ft}^{3} / \mathrm{s}\left(0.750 \mathrm{~m}^{3} / \mathrm{s}\right)$, which amounts to about 19,200 acre-ft/yr $\left(23.7 \mathrm{hm}^{3} / \mathrm{yr}\right)$. The annual discharge of Horse Creek at Wycross Ranch represents water from the Horse Creek watershed and also from the Bear Creek watershed. Except for extreme high flows, after diversion rights are satisfied, water available in Bear Creek is diverted into Horse Creek through the Wycross Ditch. The following table 1ists discharge information for the gaging station Horse Creek at Wycross Ranch for the water years (October 1 to September 30) 1966-73 (U.S. Geological Survey, 1966-73, pt. 1).

\begin{tabular}{|c|c|c|c|c|}
\hline $\begin{array}{l}\text { Water } \\
\text { Year } \\
\end{array}$ & $\begin{array}{l}\text { Mean daily } \\
\left(\mathrm{ft}^{3} / \mathrm{s}\right)\end{array}$ & $\begin{array}{l}\text { Maximum daily } \\
\left(\mathrm{ft}^{3} / \mathrm{s}\right)\end{array}$ & $\begin{array}{c}\text { Minimum daily } \\
\left(\mathrm{ft}^{3} / \mathrm{s}\right)\end{array}$ & $\begin{array}{l}\text { Annual } \\
\text { volume } \\
\text { (acre-ft) }\end{array}$ \\
\hline 1966 & 20.8 & 284 & 0.6 & 15,090 \\
\hline 1967 & 27.2 & 258 & 1.8 & 19,720 \\
\hline 1968 & 27.9 & 143 & 1.9 & 20,270 \\
\hline 1969 & 14.9 & 77 & .14 & 10,800 \\
\hline 1970 & 22.9 & 154 & .31 & 16,560 \\
\hline 1971 & 31.9 & 150 & 1.2 & 23,080 \\
\hline 1972 & 17.8 & 94 & 1.1 & 12,950 \\
\hline 1973 & 48.6 & 215 & 1.9 & 35,210 \\
\hline
\end{tabular}

The annual discharge at the gaging station, Horse Creek at Wycross Ranch, although affected by precipitation and transfer of water from Bear Creek, is mostly affected by irrigation diversions in the La Grange area. The decrease of annual streamflow in 1969 (fig. 12) may have been partly caused by a slight decrease in precipitation; however, most of the decrease was probably caused by the diversion of larger than usual amounts of surface water. Water is diverted by Horse Creek No. 1 Ditch from Horse Creek to recharge the aquifers northeast of La Grange. Ground-water pumpage by irrigation wells, particularly by wells northeast of La Grange, increased markedly in 1969 (fig. 13). In the area northeast of La Grange, ground-water pumpage was increased by the installation of 6 new irrigation wells. This increase in pumpage resulted in greater than normal amounts of surface water diverted by Horse Creek No. 1 (James Ward, oral commun., 1975), beginning in 1969, to provide water for recharging the aquifers where increased pumpage had occurred. Thus, the decrease of annual streamflow in 1969 and probably in 1972 were mostly caused by increased irrigation diversions. 

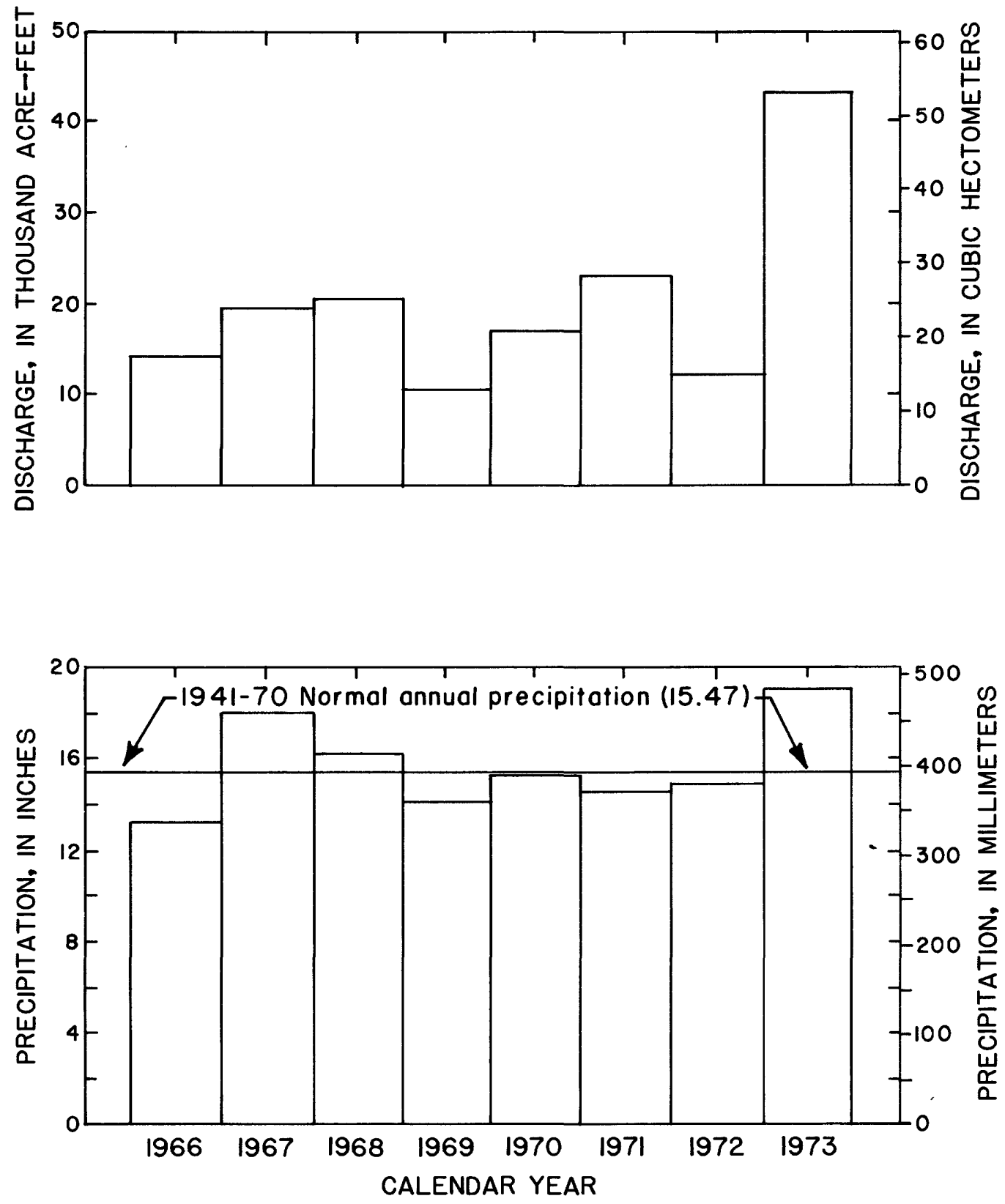

Figure 12. - Annual (calendar year) discharge of Horse Creek at Wycross Ranch near La Grange, Wyoming, and annual precipitation at La Grange, 1966-73. 


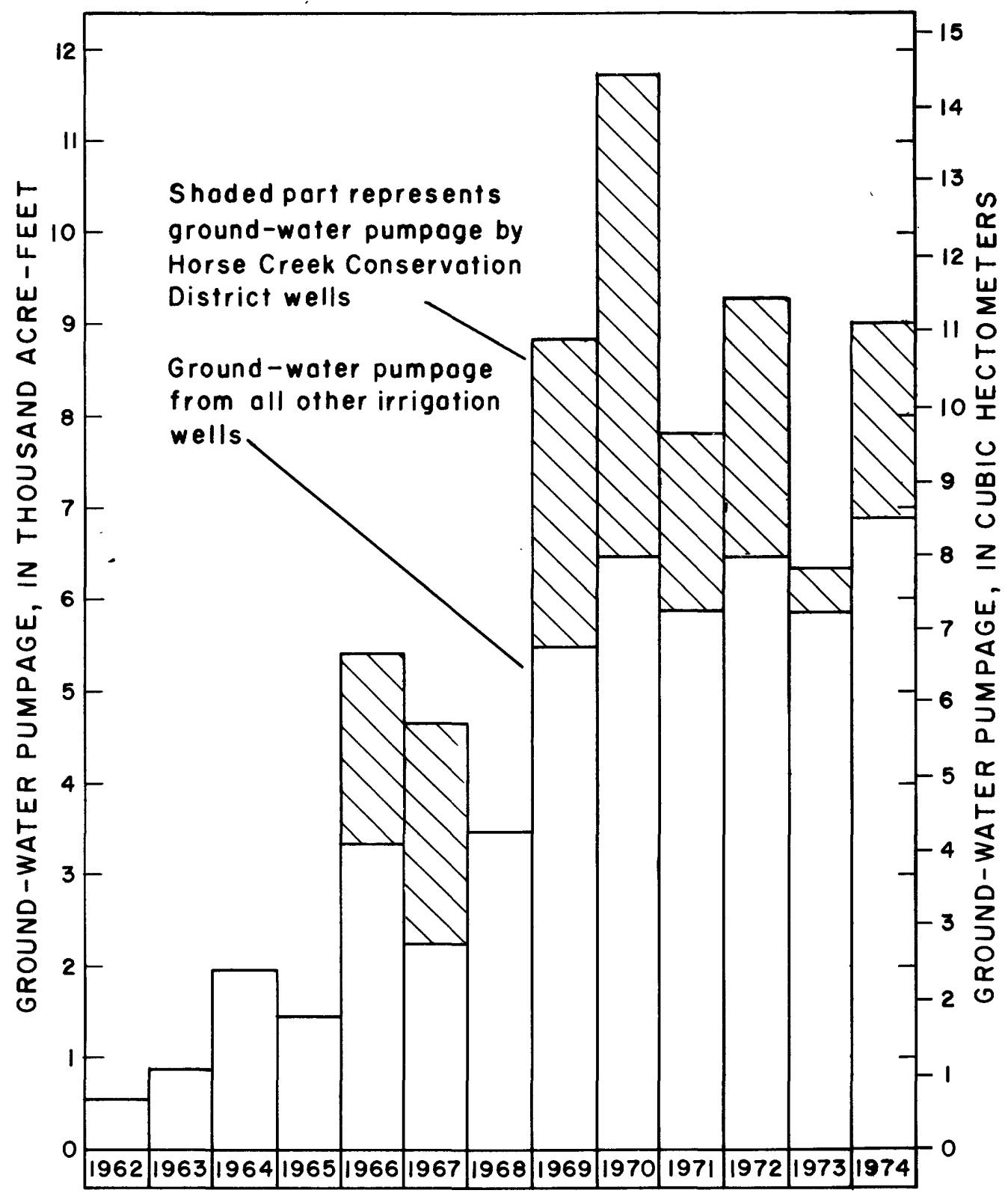

Figure 13.- Estimated annual ground-water pumpage $1962-74$ in the La Grange area. 
In the vicinity of La Grange, there are three diversions from Horse Creek above the gaging station at Wycross Ranch. These diversions shown in figure 14 are the Brown and La Grange, Horse Creek No. 1, and Lowe Cattle Co. No. 1 Ditches. Water diverted by Horse Creek No. 1 Ditch flows about $1 \mathrm{mi}(1.6 \mathrm{~km})$ north and $3 \mathrm{mi}(4.8 \mathrm{~km})$ east to Pasture Reservoir in the NW/ $\mathrm{sec}$. $31, \mathrm{~T} 20 \mathrm{~N} ., \mathrm{R}$. $60 \mathrm{~W}$. This water recharges the alluvium and underlying Brule Formation in the southeast part of T. $20 \mathrm{~N}$., R. $61 \mathrm{~W}$. Water diverted by the Brown and La Grange and the Lowe Cattle Co. No. 1 Ditches is used for irrigation of crop lands. The following table lists the available diversion data estimated for these Horse Creek diversions from 1971 to 1973. These data were collected and furnished by James Ward, Hydrographer-Commissioner for the Wyoming State Engineer's office.

$\begin{array}{lrrrr}\text { Ditch } & \underline{1971} & \underline{1972} & \underline{1973} & \underline{1974} \\ \text { Brown and La Grange } & 1,140 & 5,470 & 5,460 & 7,770 \\ \text { Horse Creek No. 1 } & \underline{a}-1, & 3,460 & 1,920 & 1,450 \\ \text { Lowe Cattle Co. No. 1 } & 280 & 1,940 & 3,460 & 3,830 \\ \text { a/ Sufficient diversion data were not available on which to } \\ \text { estimate annual volumes of water diverted. }\end{array}$

The Hawk Springs Ditch is a diversion on Horse Creek downstream from the gaging station at Wycross Ranch. During late fall, winter and spring, water is diverted through this ditch from Horse Creek into Hawk Springs Reservoir. During the fall and winter of 1972 and the spring of 1973, sufficient water was diverted through Hawk Springs Ditch to fill Hawk Springs Reservoir to its peak capacity of 16,740 acre-ft $\left(20.63 \mathrm{hm}^{3}\right)$ by April 12, 1973. This was reported to be the earliest date that Hawk Springs Reservoir was filled to capacity in at least 22 years (James Ward, written commun., 1974). Reservoir data for the early part of 1974 show that the reservoir reached its peak capacity in January, 3 months earlier than in 1973. 
In the La Grange area, the Babbitt and the Lowe Cattle Co. No. 2 Ditches divert water from Bear Creek and the Van Alton Ditch carries water from Bear Creek to land inside the La Grange area (fig. 14), although the point of diversion is located upstream of the report area. The Lowe Cattle Co. No. 2 Ditch has the number one priority on water from Bear Creek. After this diversion right and upstream diversion rights are satisfied, except for extreme high flows, Bear Creek is diverted into Wycross Ditch that flows into Horse Creek. The following table 1ists the available diversion data estimated for the Bear Creek diversions that carry water onto land within the La Grange area. These data were collected and furnished by James Ward, Hydrographer-Commissioner for the Wyoming State Engineer's office.

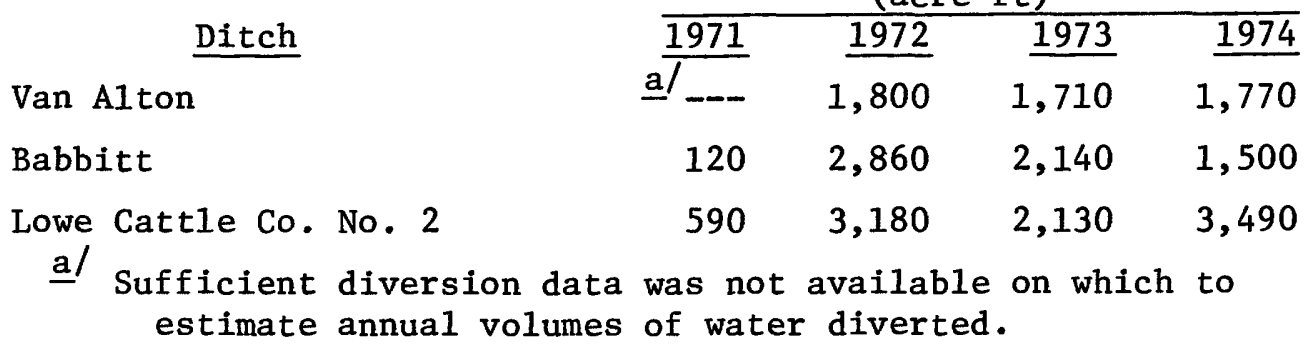

Estimated annual volume of water diverted (acre-ft)

\section{Irrigation We11s}

Of the 62 irrigation wells in the La Grange area, 14 produce from the alluvium, 28 from the Brule Formation, and 20 from a combination of the alluvium and Brule. All of the irrigation wells producing primarily from the alluvium are concentrated in secs. 32 and 33, T. 20 N., R. 61 W., and secs. 3 and 4, T. 19 N., R. 61 W. (fig. 15). A11 of these wells are less than $1 \mathrm{mi}(1.6 \mathrm{~km})$ from either Horse Creek or Bear Creek, and about one-third of these wells are less than a quarter of a mile $(0.40 \mathrm{~km})$ from one of these two streams.

Wells located in sec. 15 and the NE $\frac{1}{4}$ of sec. 22, T. 20 N., R. 61 W., belong to the Horse Creek Conservation District. This district manages Hawk Springs Reservoir and supplies water for irrigation to the conservation district's member landowners. In order to meet increased demands on water from the reservoir, nine wells were drilled during 1966 through 1969 to supplement the surface-water supply to the reservoir. These wells are pumped in the spring when insufficient surface water is available to fill the reservoir and from June through September when peak irrigation demands occur. 
Yield data and specific-capacity data are 1isted in table 3 for most of the irrigation wells and Horse Creek Conservation District wells in the La Grange area. The specific capacity for irrigation wells completed only in alluvium ranges from 8 to $59(\mathrm{gal} / \mathrm{min}) / \mathrm{ft}$ [ 2 to 12 $(1 / \mathrm{s}) / \mathrm{m}]$ with more than half the irrigation wells in the alluvium having specific capacities of $25(\mathrm{gal} / \mathrm{min}) / \mathrm{ft}[5.2(1 / \mathrm{s}) / \mathrm{m}]$ or greater.

Specific capacities of irrigation wells producing either from the Brule Formation or from both the alluvium and Brule vary considerably in different parts of the La Grange area. The specific capacities for irrigation wells completed in the Brule northwest and southeast of La Grange range from 8 to 19 (gal/min)/ft [2 to $3.9(1 / \mathrm{s}) / \mathrm{m}]$, whereas those wells northeast of La Grange range from 45 to 131 (gal/min)/ft [9.3 to $27.1(1 / \mathrm{s}) / \mathrm{m}]$. The specific capacities for irrigation wells completed in both the alluvium and Brule west and northwest of La Grange, including wells in sec. 22, T. $20 \mathrm{~N}$., R. $61 \mathrm{~W}$., range from 14 to $69(\mathrm{gal} / \mathrm{min}) / \mathrm{ft}[2.9$ to $14.3(1 / \mathrm{s}) / \mathrm{m}]$, whereas those wells northeast of La Grange range from 60 to 230 ( $\mathrm{gal} / \mathrm{min}) / \mathrm{ft}[12.4$ to $47.6(\mathrm{l} / \mathrm{s}) / \mathrm{m}]$.

Most of the irrigation wells with the highest specific capacities in the La Grange area are those northeast of La Grange and completed in the Brule Formation or in both the alluvium and the Brule. The Brule, with its secondary permeability and thus high transmissivity, probably contributes the majority of the water to the wells resulting in the high specific capacities. Alluvium, although unsaturated, overlies the Brule in the area where wells are completed only in the Brule and provides a recharge area for the Brule. Irrigation wells drilled in the Brule outside the boundaries of the alluvium do not have yields as large as most irrigation wells drilled in the Brule in areas where the alluvium is present. Secondary permeability in the Brule in the La Grange area apparently is associated with ancient drainages and topography. 


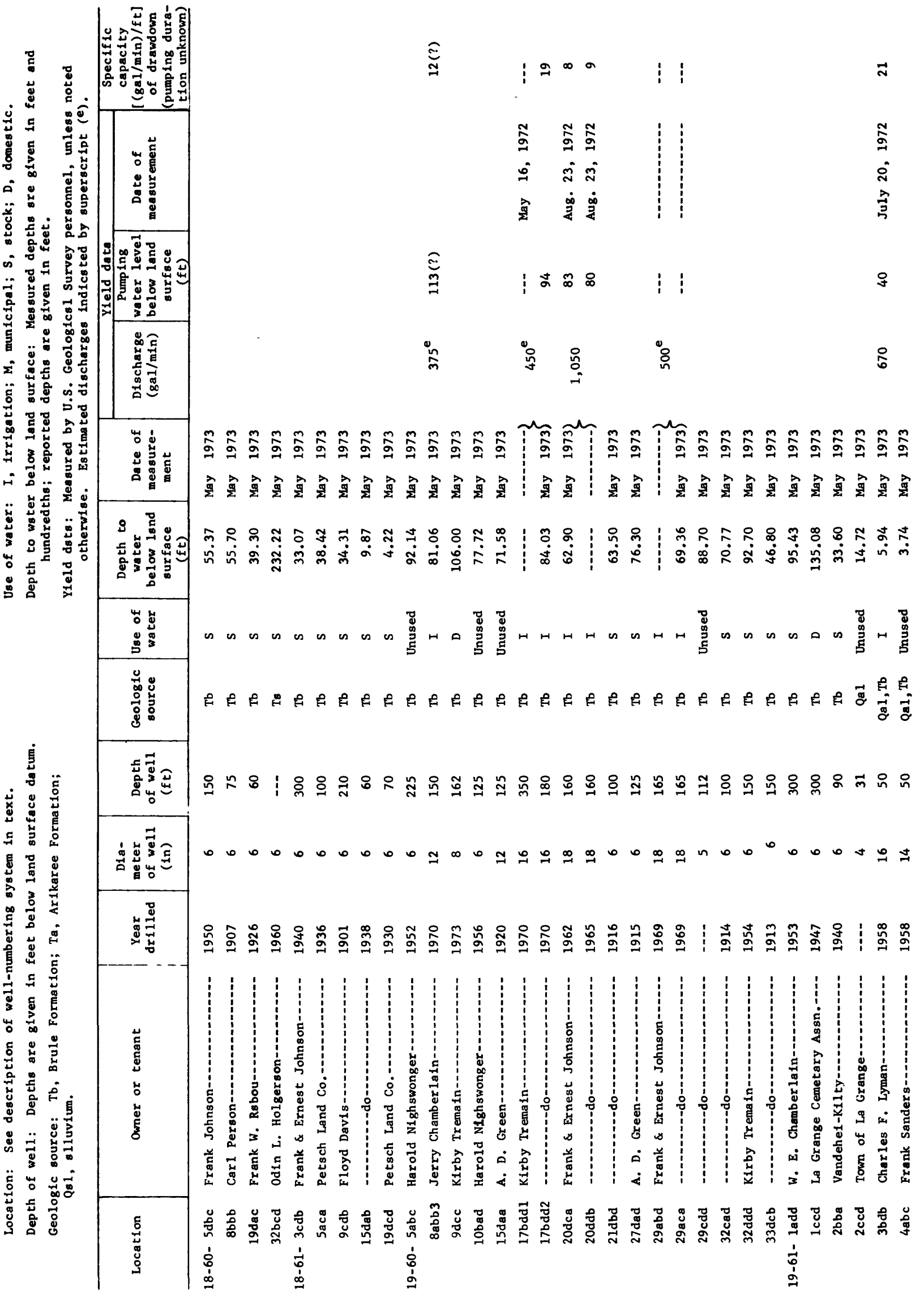




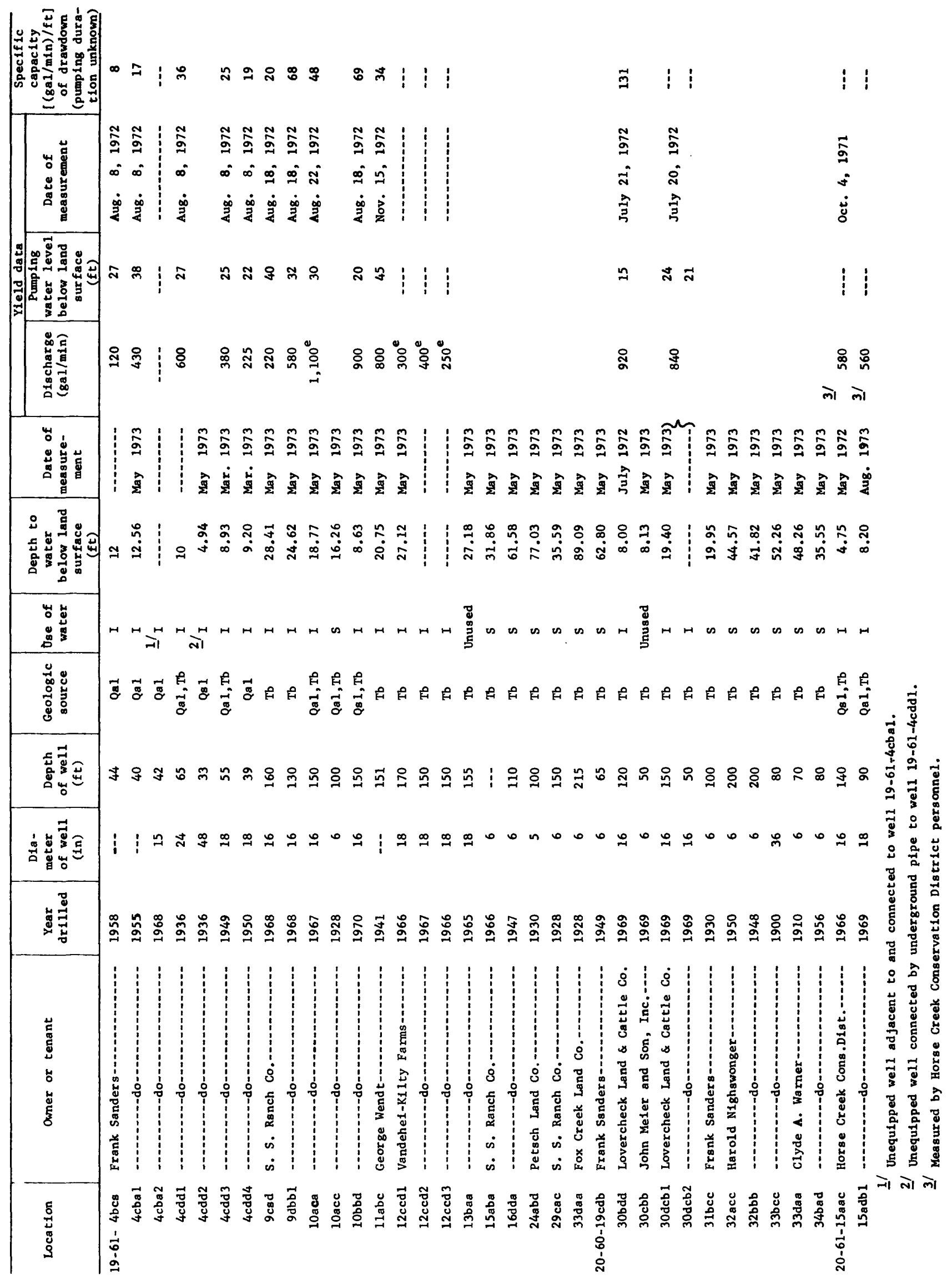




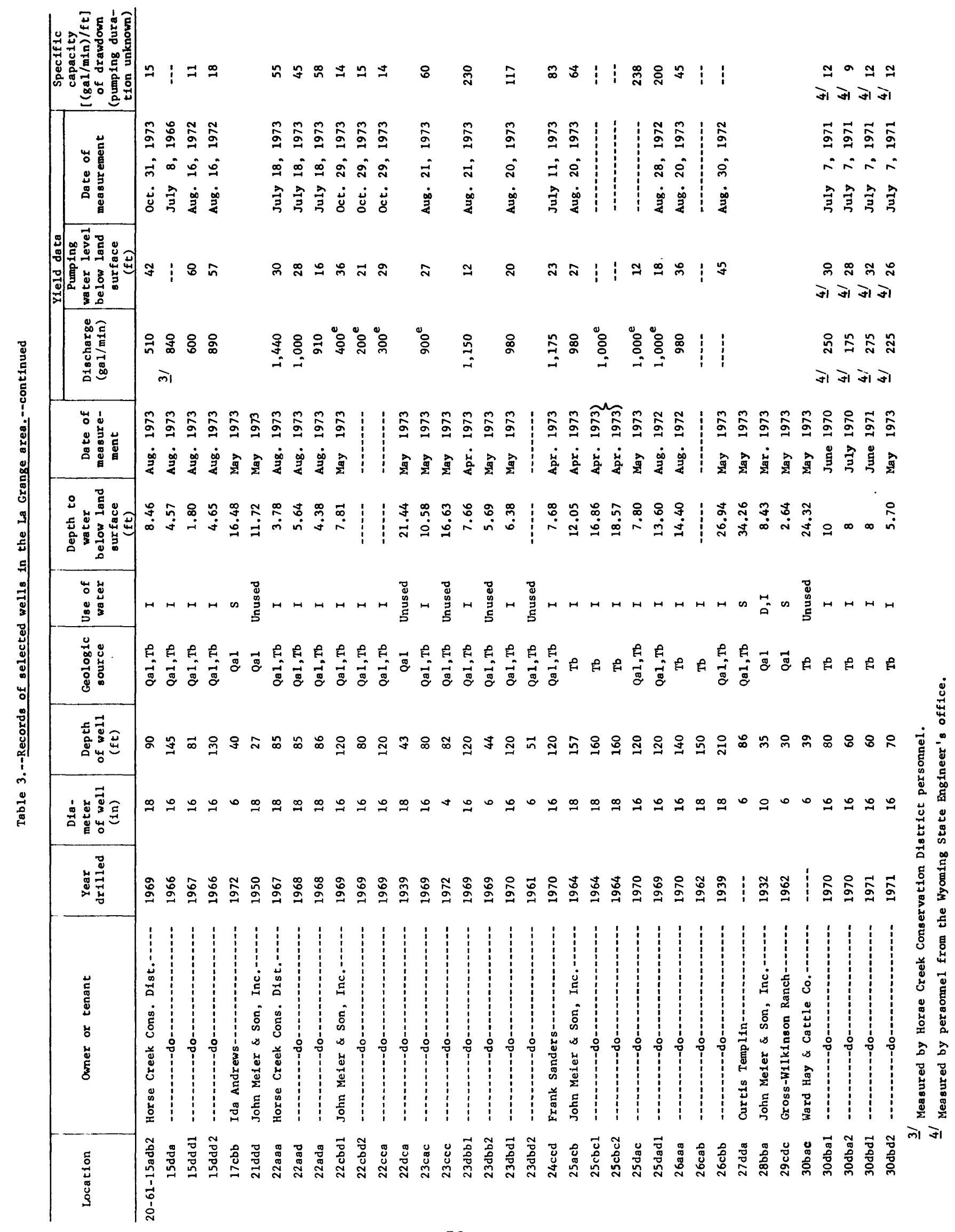




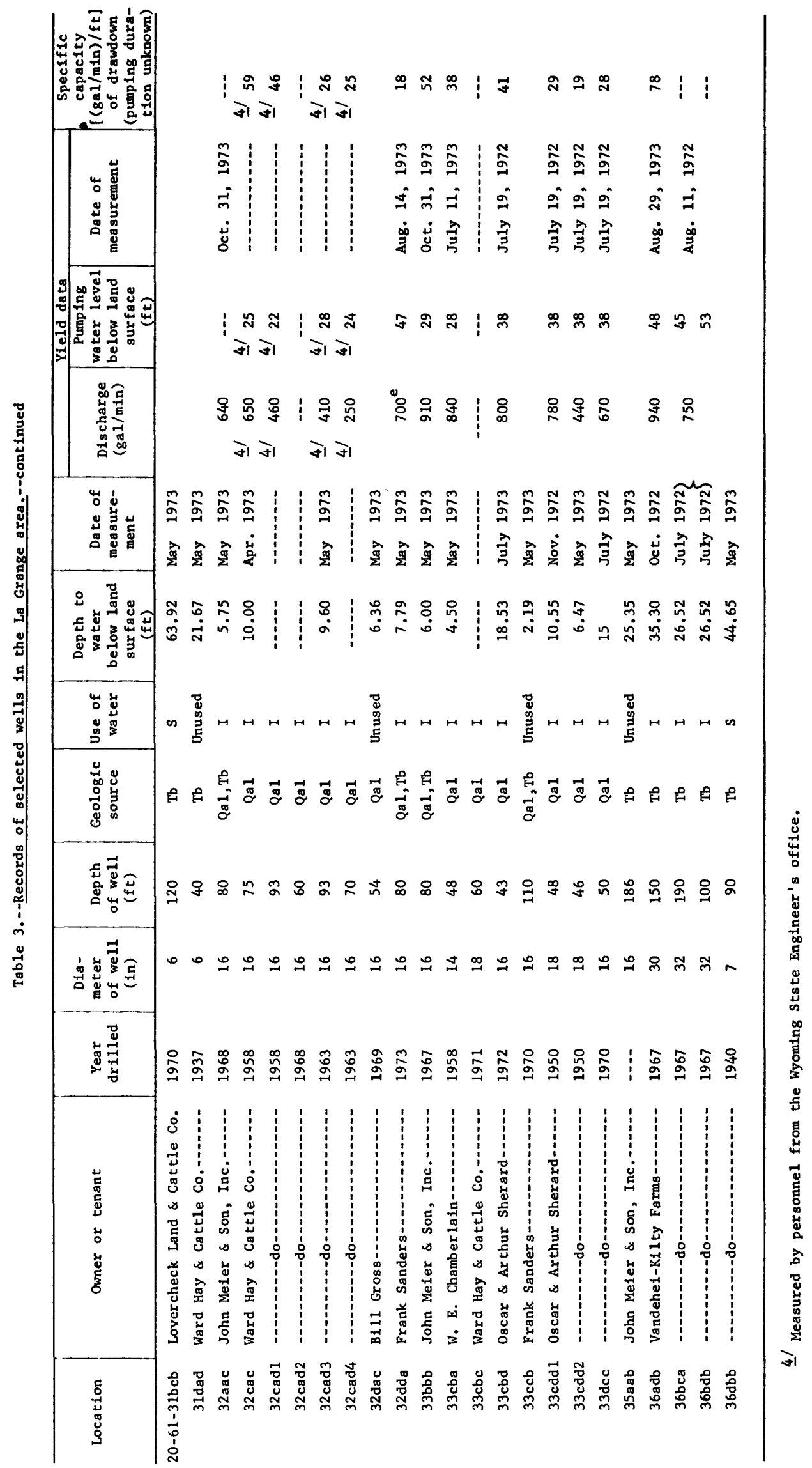


Ground-water pumpage in the La Grange area was estimated using the same methods as described in the previous section on the Albin area. Data on monthly kilowatt hours used were obtained from electric-power records of the Rural Electric Association in Lingle, Wyoming. During 1974 all irrigation wells were pumped using electric power, except for three using diesel power.

The growth of irrigation development is illustrated by the increasing annual ground-water pumpage since 1962 (fig. 13). The completion of 11 irrigation wells in 1969, the largest number installed in a single year, resulted in the largest annual increase in pumpage during 1969. From 1969 through 1974, ground-water pumpage for irrigation in the La Grange area has remained stable (fig. 13). Pumpage data for the Horse Creek Conservation District wells is shown separately in figure 13 because the water pumped from them is used outside the La Grange area.

Ground-water pumpage for irrigation is dependant on the peak demands of the crops, temperature, and on the amounts and timing of precipitation. The peak ground-water pumpage normally occurs during June, July, and August, as shown in figure 16, because this is the growing season for the crops grown in the La Grange area. Ground-water pumpage in 1973 was less than in 1972 because annual precipitation at La Grange during 1973 was 19.10 in (485.1 mm) compared with 14.85 in $(377.2 \mathrm{~mm}$ ) in 1972. About 4 in (102 mm) of rain fell during July 1973, thus reducing the normal peak ground-water usage during that month. In contrast to 1973, annual precipitation at La Grange during 1974 was only 10.05 in $(255.3 \mathrm{~mm})$, the second lowest annual total recorded since 1911 . The dry year is reflected by an increase in ground-water pumpage in 1974. 


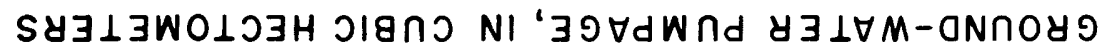

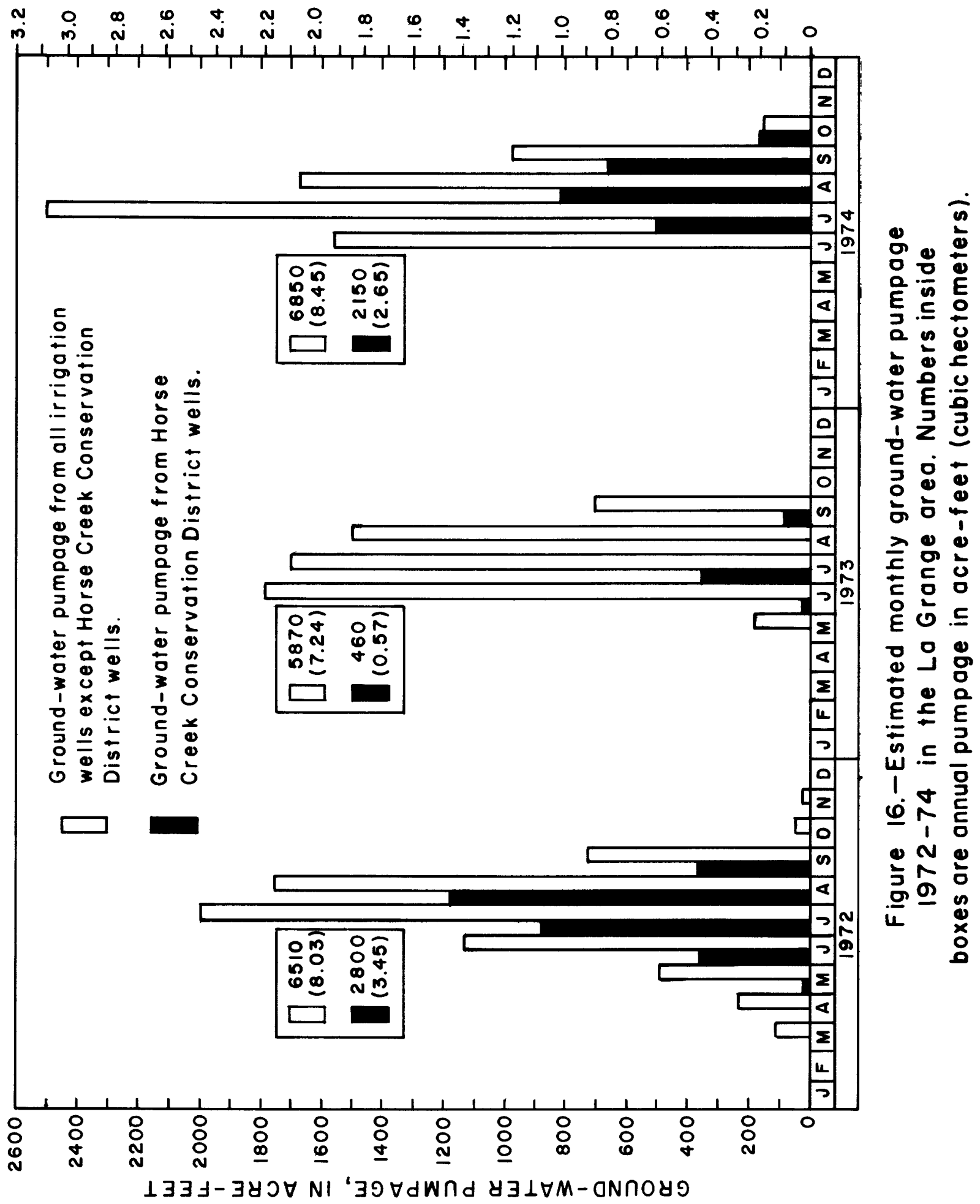


In the La Grange area at the end of 1974 about 10,110 acres $(4,092$ hectares) are being irrigated with surface water and ground water. of this total acreage, 1,290 acres (522 hectares) are along the upper part of Horse Creek in Laramie County and about 8,820 acres (3,569 hectares) are in Goshen County, mostly in the vicinity of La Grange. In some areas, the same acreage is irrigated by both surface and ground water. The location of irrigated acreage, diversion ditches, and sources of water used (surface or ground water) are shown in figure 14 . Of the 8,820 acres $(3,569$ hectares) in the Goshen County part of the La Grange area, about 4,890 acres $(1,979$ hectares) are irrigated with ground water, about 2,600 acres $(1,050$ hectares) with surface water, and about 1,330 acres (538 hectares) with a combination of both ground water and surface water. Nearly all the acreage irrigated by ground water is irrigated using center-pivot sprinklers, and nearly all the acreage irrigated by surface water is irrigated using gravity methods. Centerpivot sprinklers are used to irrigate land with surface water in secs. 21 and 28, T. $20 \mathrm{~N} .$, R. $61 \mathrm{~W}$. The acreage irrigated by ground water and related surface-water was compiled from maps showing irrigated acreage prepared by the Wyoming Water Planning Program and from other information furnished by the Wyoming State Engineer's office.

\section{The Water Table}

\section{Configuration}

The map showing water-table contours (fig. 15) in the La Grange area shows that ground-water movement is generally northward, in the direction of the maximum slope of the water table. The steepening (closer contour spacing) or flattening (wider contour spacing) of the slope of the water table is caused by local variations in transmissivity.

It is assumed that the hydraulic interconnection between the alluvium and the Brule Formation is sufficient that one water table may be contoured throughout the study area. In the Brule, local anomalies in the water-table contours are probably due to variations in transmissivity. The water-table high in sec. 5, T. 19 N., R. 60 W., is possibly water perched in the Brule due to local differences in permeability. Throughout the area, but particularly northeast of La Grange where the Brule is known to have secondary permeability, the water-table contours depict the water-table configuration and movement only on a regional scale. Locally, where there are significant directional variations in hydraulic conductivity, ground water may move in the direction of greater hydraulic conductivity, which may not be perpendicular to the water-table contours. 
On the water-table contour map of the La Grange area (fig. 15), a ground-water divide is shown in the southern part of sec. 29 and northern part of sec. 32, T. $20 \mathrm{~N}$., R. $60 \mathrm{~W}$. Control available to the north was not sufficient to adequately define the location and extent of this divide. Ground water moving northward in sec. 32 does not cross this divide but turns eastward toward Pumpkin Creek in Nebraska or westward into the alluvium. A gentle topographic divide coincides with the location of the ground-water divide. Thus, the configuration of the water-table surface is a subdued reflection of the topography.

The configuration of the water table is influenced by Horse Creek and Bear Creek in the La Grange area. These streams are flowing generally to the north, except where they enter the area from the west. In the southern part of the La Grange area in Laramie County, the watertable contours indicate that ground water is moving into Horse Creek. In secs. 11 and 14, T. 19 N., R. 61 W., water-table contours indicate that Horse Creek may be losing water. Adequate water-level data was not available to delineate other losing or gaining reaches of Horse Creek and Bear Creek.

\section{Fluctuation}

The water table in the La Grange area fluctuates in response to precipitation, surface-water application, pumpage, and evapotranspiration. From 1972 through 1974, water levels were measured monthly in 24 observation wells including two wells equipped with graphic waterstage recorders. Water-level fluctuations, in the northern part of the La Grange area, were observed primarily in areas where concentrated ground-water development has taken place.

Hydrographs for the two observation wells equipped with graphic water-stage recorders are shown in figure 17. Both of these wells fully penetrate the alluvium and are bottomed in the Brule Formation. Waterlevel changes resulting from different conditions are recorded at each of these observation wells.

The water-level fluctuations in well 19-61-4abc are representative of fluctuations of the shallow water table in the area between Horse Creek and Bear Creek. Fluctuations in this area are caused by evapotranspiration, pumpage, infiltration of surface-water irrigation and precipitation, and streamflow in Horse Creek. Diurnal water-level fluctuations as large as $0.1 \mathrm{ft}(0.03 \mathrm{~m})$ result from evapotranspiration during summer months at well 19-61-4abc. Precipitation causes watertable fluctuations directly by recharging the aquifer and indirectly by influencing pumpage, surface-water irrigation, and the flow of Horse Creek. Precipitation during 1973 was about 3.6 in (91 mm) above average, and during 1974 it was about 5.4 in $(138 \mathrm{~mm}$ ) below average. The hot, dry summer of 1974 caused increased ground-water pumpage and decreased surface-water diversion in the La Grange area, which resulted in greater water-level declines during the 1974 irrigation season than during 1973. Recharge from surface-water irrigation south of well 19-61-4abc is shown as small peaks on the hydrograph during the summer. 


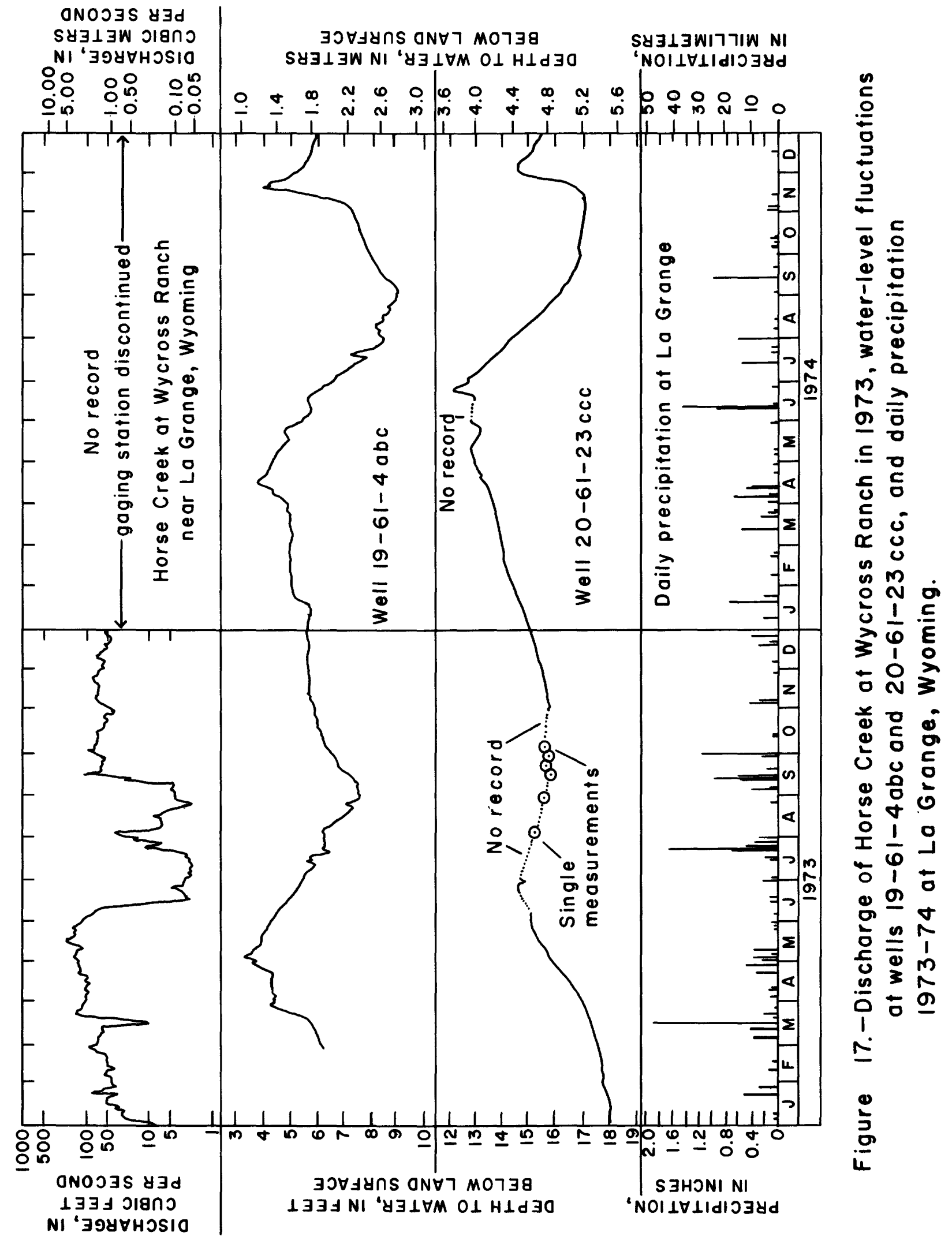


Surface-water users in the La Grange area irrigate whenever the water is available. After a dry summer, surface water was available in October and November of 1974, resulting in late irrigation of croplands. Recharge from this irrigation caused the major water-level rise shown on the hydrograph in 1974 (fig. 17) during the latter part of November. Records of water levels in wells located northwest of well 19-61-4abc did not show this water-level rise. Fluctuations of the water table caused by precipitation are subdued and concealed on the hydrograph by the effects of pumping and surface-water application. Comparison of the hydrograph for Horse Creek and the hydrograph of wel1 19-61-4abc (fig. 17) for 1973 show some correlation during March, April, and May. The peak in discharge of Horse Creek at the end of July and the sudden rise in early September are reflected to a smaller degree by water-1evel changes in well 19-61-4abc. Water levels during the spring of 1975 were about $2 \mathrm{ft}(0.6 \mathrm{~m})$ lower than those measured during the spring of 1973 and 1974. Much of this decline is probably caused by increased pumpage during the 1974 irrigation season.

The second observation well equipped with a recorder in the La Grange area is well 20-61-23ccc (fig. 17). It is downgradient from irrigation wells that pump about one-third of the total annual pumpage by irrigation wells in the La Grange area. Evapotranspiration does not cause any detectable water-level changes. The water-level fluctuations recorded at wel1 20-61-23ccc are predominantly influenced by precipitation (directly and indirectly), ground-water pumpage, and surface-water recharge.

Ground-water pumpage by the irrigation wells upgradient of well 20-61-23ccc was about the same for 1973 and 1974. Lands west and southwest of this observation well are irrigated by surface water diverted by the Lowe Cattle Co. No. 1 Ditch. Diversions by this ditch during June, July, and August of 1973 were greater than for the same period in 1974. Surface-water diversions during 1973 by Horse Creek No. 1 Ditch to Pasture Reservoir in the NW/ sec. 31, T. 20 N., R. 60 W. were greater than during 1974. No surface water was diverted by Horse Creek No. 1 Ditch during June, July, and August of 1974. The recharge from these surface-water diversions plus higher precipitation during 1973 account for less water-level decline during the 1973 irrigation season as compared with water-level decline in 1974. The higher water level recorded at well 20-61-23ccc during late November and early December of 1974 was due to surface-water recharge from the diversion of surface water by Lowe Cattle Co. No. 1 Ditch. Water had not been diverted by this ditch during November and December since 1971. 
Water-level fluctuations resulting from surface-water irrigation in the area irrigated by the Lowe Cattle Co. No. 1 Ditch are shown on the hydrograph of well 20-61-2lddd (fig. 18). This well is an unused irrigation well with casing perforated from the surface to its total depth of $27 \mathrm{ft}$ $(8.2 \mathrm{~m})$. It is completed through the alluvium and a few feet into the Brule. The hydrograph for this well shows the water table to be lowest during the spring and highest during summer irrigation. A lateral ditch fed by Lowe Cattle Co. No. 1 Ditch passes within a few feet of this well and accounts for the peaks noted in figure 18. Land irrigated with surface water lies to the south and upgradient from wel1 20-61-21ddd (fig. 14). Thus, the water level in this well is affected to a greater degree by surface-water recharge than by ground-water pumpage by the

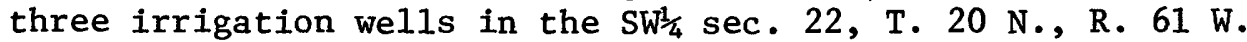

Surface-water diversions to Horse Creek No. 1 Ditch are used primarily to recharge the alluvium and Brule Formation north and northeast of La Grange. All the observation wells downgradient from Pasture Reservoir, where Horse Creek No. 1 Ditch empties, show waterlevel fluctuations resulting from this recharge. The hydrograph for well 20-60-30cbb (fig.18) shows water-level fluctuations similar to those measured in we1ls 20-61-23dbb2 and 20-61-25cbc2. Most of the water-level peaks and rises in these three wells occur at about the same time that Horse Creek No. 1 Ditch is flowing (fig. 19). These wells in and near the trough in the water table delineated by the 4,490 ft $(1,369 \mathrm{~m})$ contour line (fig. 15) show the effects of surfacewater recharge first. Water-level fluctuations at wells 20-61-23ccc (fig. 17) and 20-61-27dda (fig. 20) are more subdued and lag in response to surface-water recharge by Horse Creek No. 1 Ditch.

The fluctuation of the water table in the area west of Bear Creek is represented by the hydrograph for well 20-61-30bac (fig. 18). The water-level fluctuations shown for this well are very similar to the fluctuations of water levels measured in wells $20-61-31 \mathrm{bcb}$ and 20-61-31dad.

We11 20-61-35aab is completed in the Brule Formation. This we11 responds to pumping from irrigation wells half a mile $(0.8 \mathrm{~km})$ to the east and northeast as indicated by large seasonal water-level fluctuations (fig. 18). The response of this well indicates that the zones of secondary permeability, from which the irrigation wells are pumping, extends to this location. A comparison of the hydrograph for well 20-61-35aab during 1972 and 1973 with the estimated monthly discharge of Horse Creek No. 1 Ditch (fig. 19) shows spring and fall water-level rises in the well to correlate with the operation of Horse Creek No. 1 Ditch. There is no correlation during July and August because the diversions into Horse Creek No. 1 Ditch took place only during the last half of each month and the influence from irrigation wells pumping in the vicinity of well 20-61-35aab was greater than the recharge effect. 


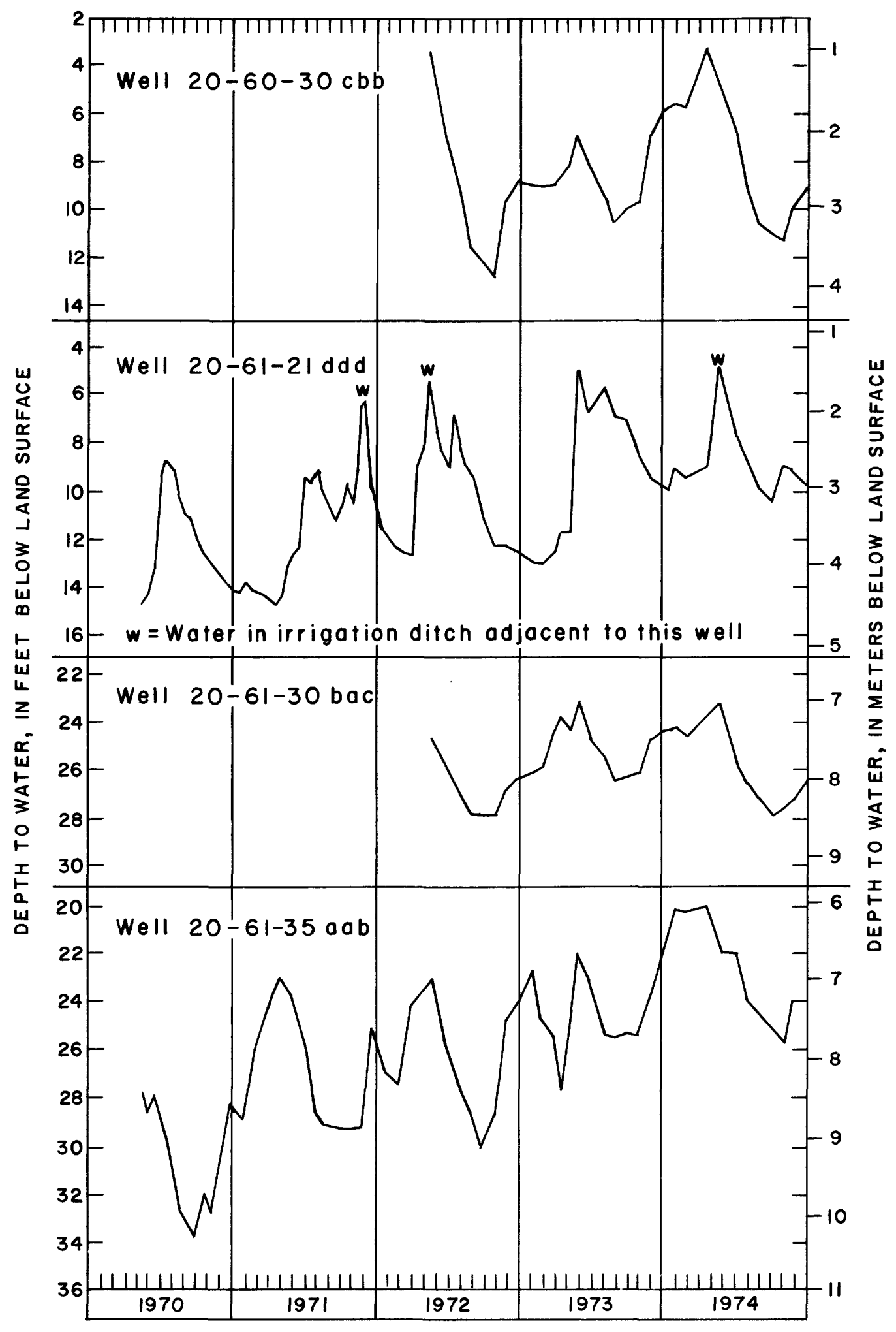

Figure 18.-Seasonal water-level fluctuations 1970-74. 


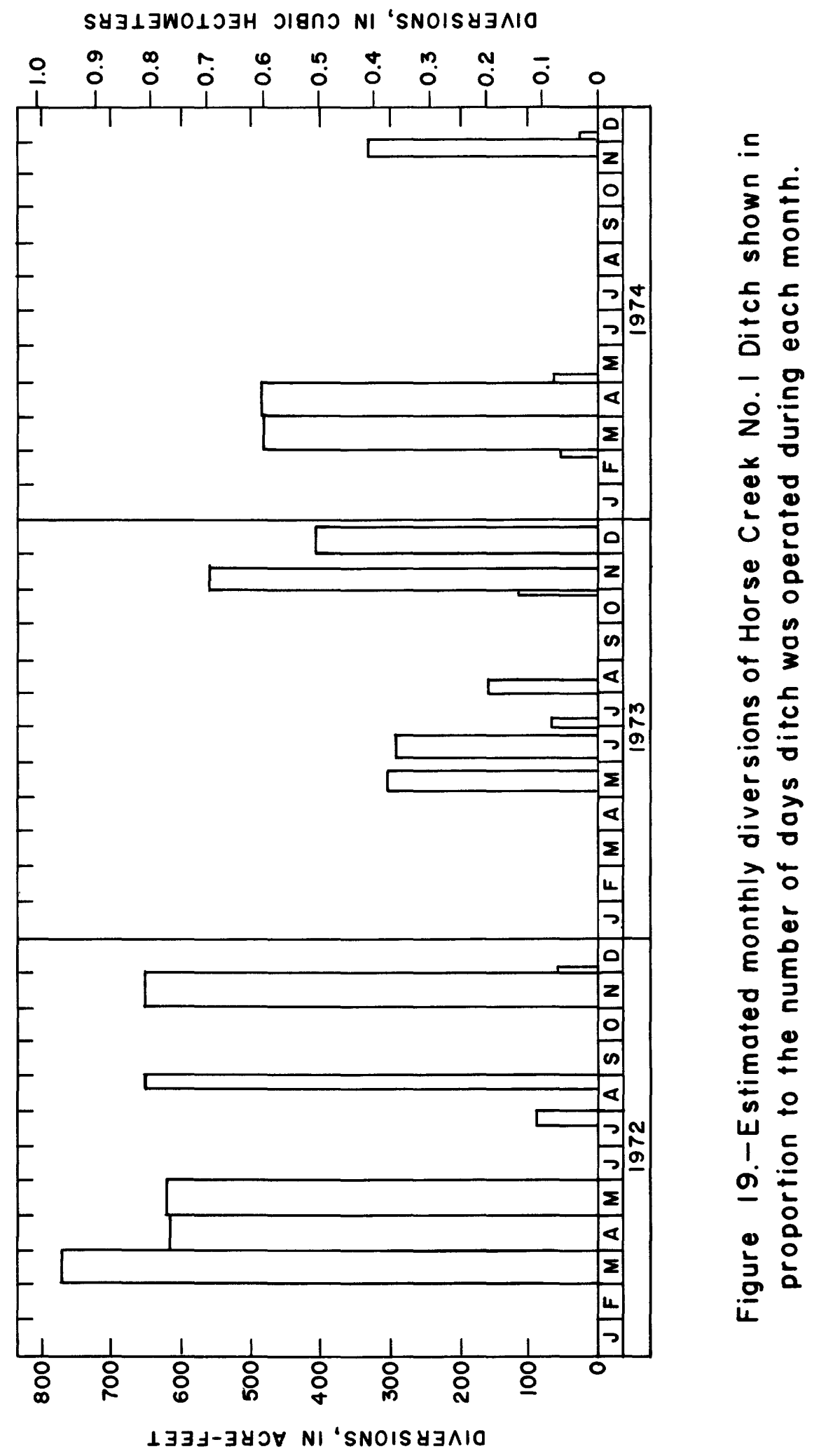




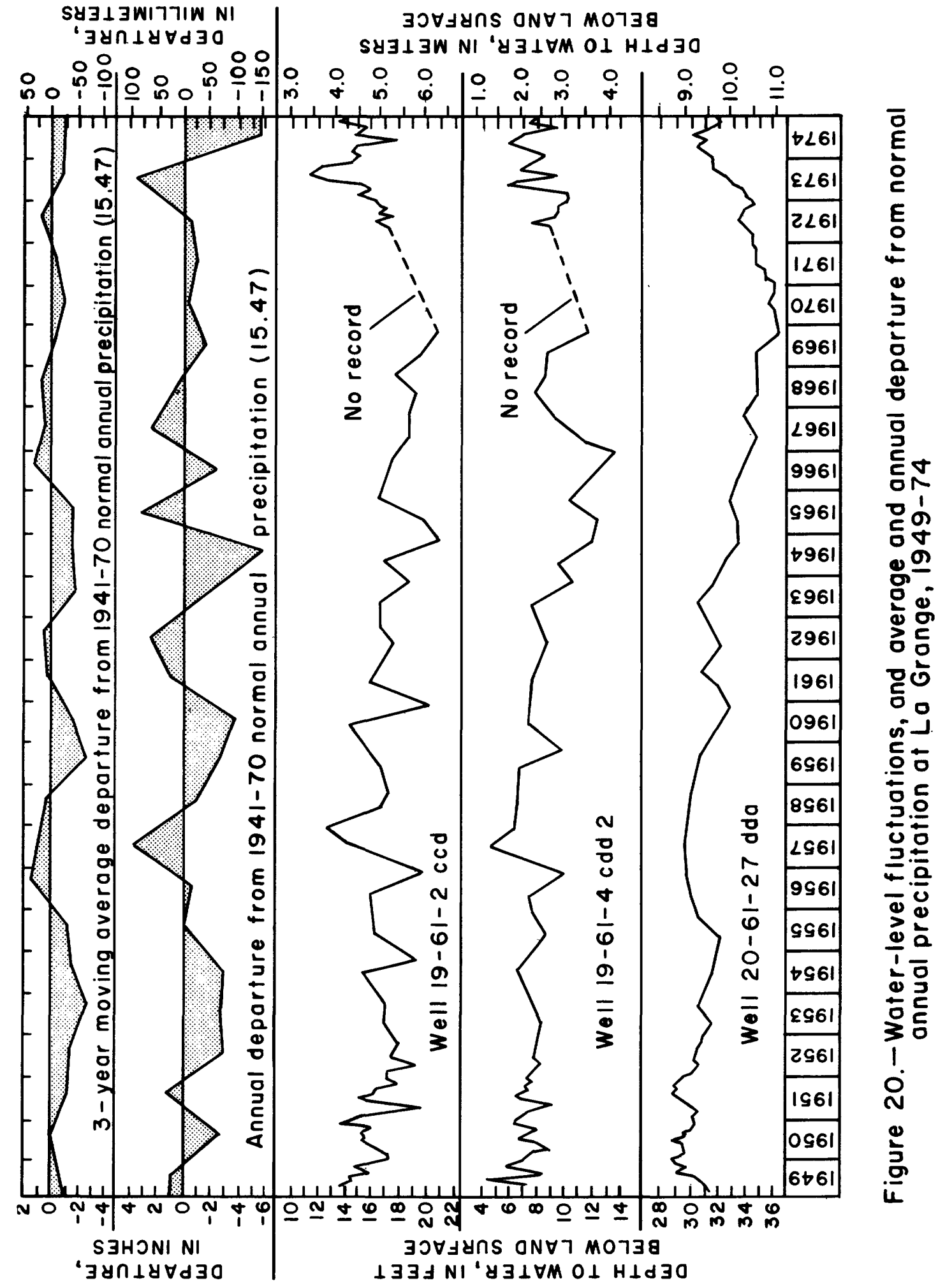


Departure from normal annual precipitation (1941-70) for the period 1949 to 1974 (U. S. Department of Commerce, 1949-74) is shown on two graphs in figure 20. To obtain the 3-year moving-average departure, the departure from normal annual precipitation for a year was averaged with the departure for the previous year and following year. Using this method for each year, the 3-year moving-average departure was calculated for the period. The 3-year average departure is useful for showing long-term trends. The annual-departure graph often can be used for better correlation of water-level hydrographs with precipitation.

Long-term water-level information is available for only three observation wells in the La Grange area. The hydrographs for these three wells, 19-61-2ccd, 19-61-4cdd2, and 20-61-27dda are shown in figure 20. Other than the monthly water-level measurements made during 1949-51 and 1972-74, most other water-level measurements were made either once or twice a year. The hydrographs for these three observation wells show a gradual downward trend of the water table throughout most of the period from about 1949 to 1969. Much of this decline of the water level in these three wells can be attributed to generally belowaverage precipitation. Well 20-61-27dda shows the downward trend most clearly from about 1962 to the latter part of 1969. Since 1969, there has been a gradual rise in the water level in these three observation wells until the water level has returned to nearly the same level in 1974 as in 1949.

Wells 19-61-2ccd and 19-61-4cdd2 are both completed only in the alluvium. Surface water is diverted by the Brown and La Grange Ditch and applied to lands upgradient from these wells. During each year of 1972 and 1973, about 5 times more water was diverted by the Brown and La Grange Ditch than during 1971. Increased recharge to the alluvium from this surface-water irrigation plus above-average precipitation in 1973 resulted in the water-level rises after 1971 in observation wells 19-61-2ccd and 19-61-4cdd2. The rising trend of the water table at La Grange after 1971 is shown by the hydrograph for well 19-61-2ccd (fig. 20). Additional evidence of recharge from surface-water irrigation is illustrated by the $5 \mathrm{ft}(2 \mathrm{~m})$ water-level rise from May to September 1973 in the two irrigation wells located in the north half of sec. 10 , T. 19 N., R. $61 \mathrm{~W}$.

We11 20-61-27dda is completed in both alluvium and Brule with about $15 \mathrm{ft}(4.6 \mathrm{~m})$ of saturated thickness in the alluvium. From 1962 to 1970 all but one of the irrigation wells east and northeast of well 20-61-27dda were drilled, and over half of them were drilled during 1969 and 1970. This resulted in increased ground-water pumpage beginning in 1969 as previously shown in figure 13. The increased water-level decline in the latter part of 1969 in well 20-61-27dda is probably caused by the pumpage increase. Additional water-table declines were averted by increased diversions of surface water by Horse Creek No. 1 Ditch to Pasture Reservoir after 1969 (James Ward, oral commun., 1975). Thus, although pumpage increased in 1969, the water level rose after 1969 in well 20-61-27dda (fig. 20) because of increased surface-water recharge upgradient. 


\section{Stream-Aquifer Relationship}

Ground-water pumpage from the alluvium in the area between and adjacent to Horse Creek and Bear Creek could deplete the flow of the streams directly by diverting water from the streams to wells, or indirectly by intercepting ground water that would otherwise discharge into the streams. If the streams are being depleted directly, this would occur during and for some time after pumping stops (Jenkins, 1970, p. 1); therefore, streamflow measurements made during the pumping period should indicate whether the streams are losing water.

Discharge measurements were made along Horse Creek on July 23, 1973, during a time of low flow due to diversions and when most irrigation wells between Horse Creek and Bear Creek were pumping. Discharge-measurement data is given in the following table:

\section{Location}

1 - Below Brown and La Grange diversion

2 - At S. S. Ranch (19-61-11bda)

3 - Above Horse Creek No. 1 diversion

4 - Below Horse Creek No. 1 diversion

5 - Sherard's Ranch (19-61-3bbb)

6 - At gaging station at Wycross Ranch

\begin{tabular}{cc}
\multicolumn{2}{c}{ Discharge } \\
$\begin{array}{c}\text { Measured } \\
\left(\mathrm{ft}^{3} / \mathrm{s}\right)\end{array}$ & $\begin{array}{c}\text { Net } \\
\text { Change } \\
\left(\mathrm{ft}^{3} / \mathrm{s}\right)\end{array}$ \\
3.6 & -0.3 \\
3.1 & -.2 \\
1.4 & -1.7 \\
7.2 & +5.8 \\
a/ 9.9 &
\end{tabular}

a/ The discharge of Horse Creek at Wycross Ranch was computed from the gage height measured at the gaging station at about the same time that the discharge was measured at Sherard's Ranch.

The net changes of discharge between measurement sites 1 and 2 and 2 and 3 are smal1 and are not within the accuracy of measurement. However, the small net changes between measurement sites 1 and 3 suggest that Horse Creek is probably not gaining or losing significant amounts of water in the reach. 
Between measurement sites 4 and 5 , Horse Creek gained $5.8 \mathrm{ft}^{3} / \mathrm{s}$ $\left(0.16 \mathrm{~m}^{3} / \mathrm{s}\right)$. About $1 \mathrm{ft}^{3} / \mathrm{s}\left(0.03 \mathrm{~m}^{3} / \mathrm{s}\right)$ of this gain flowed into Horse Creek between measurement sites 4 and 5 from a drainage ditch. The ditch drains a marsh maintained by ground-water discharge that is probably mostly return flow from irrigation. The water table in much of the south half of sec. 3, T. 19 N., R. 61 W., is just below or above land surface during late summer and early fall. It is reported that this condition has become more prevalent in recent years making a larger and larger part of the hay meadows in sec. 3 difficult to harvest. The water-table build up in approximately the south half of sec. 3 and southeast part of sec. 4, T. $19 \mathrm{~N}$., R. $61 \mathrm{~W}$. is a result of both surface and ground-water irrigation in the vicinity (fig. 14), especially south of Highway 151. The gain in streamflow of $5.8 \mathrm{ft}^{3} / \mathrm{s}\left(0.16 \mathrm{~m}^{3} / \mathrm{s}\right)$ between measurement sites 4 and 5 indicates that any direct streamflow depletion that may be caused by the pumping of wel1 19-61-3bdb is less than ground-water discharge to Horse Creek.

The net change in discharge of Horse Creek between measurement sites 5 and 6 was estimated from the discharge at Sherard's Ranch, the discharge at the gaging station at Wycross Ranch, and from information about the diversions of the Lowe Cattle Co. No. 1 Ditch. The diversion for the Lowe Cattle Co. No. 1 Ditch is about half a mile $(0.8 \mathrm{~km})$ downstream from Sherard's Ranch and upstream of the Wycross Ditch. On July 23, no water was diverted by the Wycross Ditch into Horse Creek. Assuming that Lowe Cattle Co. No. 1 Ditch did not divert any water from Horse Creek on July 23, the minimum gain in streamflow between measurement sites 5 and 6 or the difference between the flow at Sherard's Ranch and the flow at the gaging station is $2.7 \mathrm{ft}^{3} / \mathrm{s}\left(0.08 \mathrm{~m}^{3} / \mathrm{s}\right)$. However, the hydrographer-commissioner working in the La Grange area, James Ward, reports (oral commun., 1974) that the Lowe Cattle Co. No. 1 Ditch normally diverts all of the flow of Horse Creek during the irrigation season. Assuming that this ditch was diverting all the water in Horse Creek on July 23, then Horse Creek gained about $9.9 \mathrm{ft}^{3} / \mathrm{s}\left(0.28 \mathrm{~m}^{3} / \mathrm{s}\right)$ between the diversion and the gaging station at Wycross Ranch. This gain in streamflow compares favorably with a gain of 4 to $5 \mathrm{ft}^{3} / \mathrm{s}$ (about $0.1 \mathrm{~m}^{3} / \mathrm{s}$ ) estimated by James Ward (oral commun., 1974) for the same reach when all the flow of Horse Creek is diverted by Lowe Cattle Co. No. 1 Ditch. Therefore, between measurement sites 5 and 6 , Horse Creek gained from 2.7 to $9.9 \mathrm{ft}^{3} / \mathrm{s}\left(0.08\right.$ to $\left.0.28 \mathrm{~m}^{3} / \mathrm{s}\right)$ during the 1973 irrigation season.

Discharge measurements of Horse Creek during July 1973 indicate that Horse Creek below Horse Creek No. 1 Ditch was not being depleted appreciably by pumping. There is no indication of decline in the water table near the stream. Recharge from precipitation and surface-water irrigation has maintained the water-table gradient toward the streams. This is indicated by streamflow gains in some reaches of Horse Creek and water-level measurements in wells near the stream as previously described in the section on Fluctuation and shown by the hydrograph for well 19-61-2ccd (fig. 20). 
Three discharge measurements were made November 15, 1973 on the upper part of Bear Creék in the La Grange area. The measurement sites were downstream from the U.S. 85 bridge, at the bridge over State Highway 151, and about half a mile $(0.8 \mathrm{~km})$ south of the Babbitt diversion. There was no significant difference in the discharge measured at each location and, therefore, no gain or losses in discharge of Bear Creek.

\section{Chemical Quality of the Water}

Chemical analyses of ground water in the La Grange area are shown in table 4. Ground-water samples were collected in order to determine the general quality of the ground water and to provide background data for monitoring future changes in ground-water quality. The chemical analyses of four ground-water samples contained in a report by Rapp and others (1957, p. 76 and 78) are included in table 4. Comparison of the older analyses with recent data indicates that, at least locally, irrigation has not caused any significant changes in water quality.

Dissolved-solids concentration in water from wells developed only in the alluvium ranged from 359 to $438 \mathrm{mg} / 1$. Dissolved-solids concentration in water from wells developed only in the Brule Formation ranged from 241 to $676 \mathrm{mg} / 1$. For a general discussion of water quality for that part of the La Grange area located in Goshen County, see Rapp and others (1957, p. 73-94), and, for that part located in Laramie County, see Lowry and Crist (1967, p. 50-57).

Chemical analyses of surface-water samples collected monthyy from July 1969 to September 1972 at the gaging station on Horse Creek at Wycross Ranch have been published (U. S. Geological Survey, 1970-72, pt. 2). Rapp and others (1957, p. 81) and Lowry and Crist (1967, p. 54) published chemical analyses of water from Horse Creek and Bear Creek. 


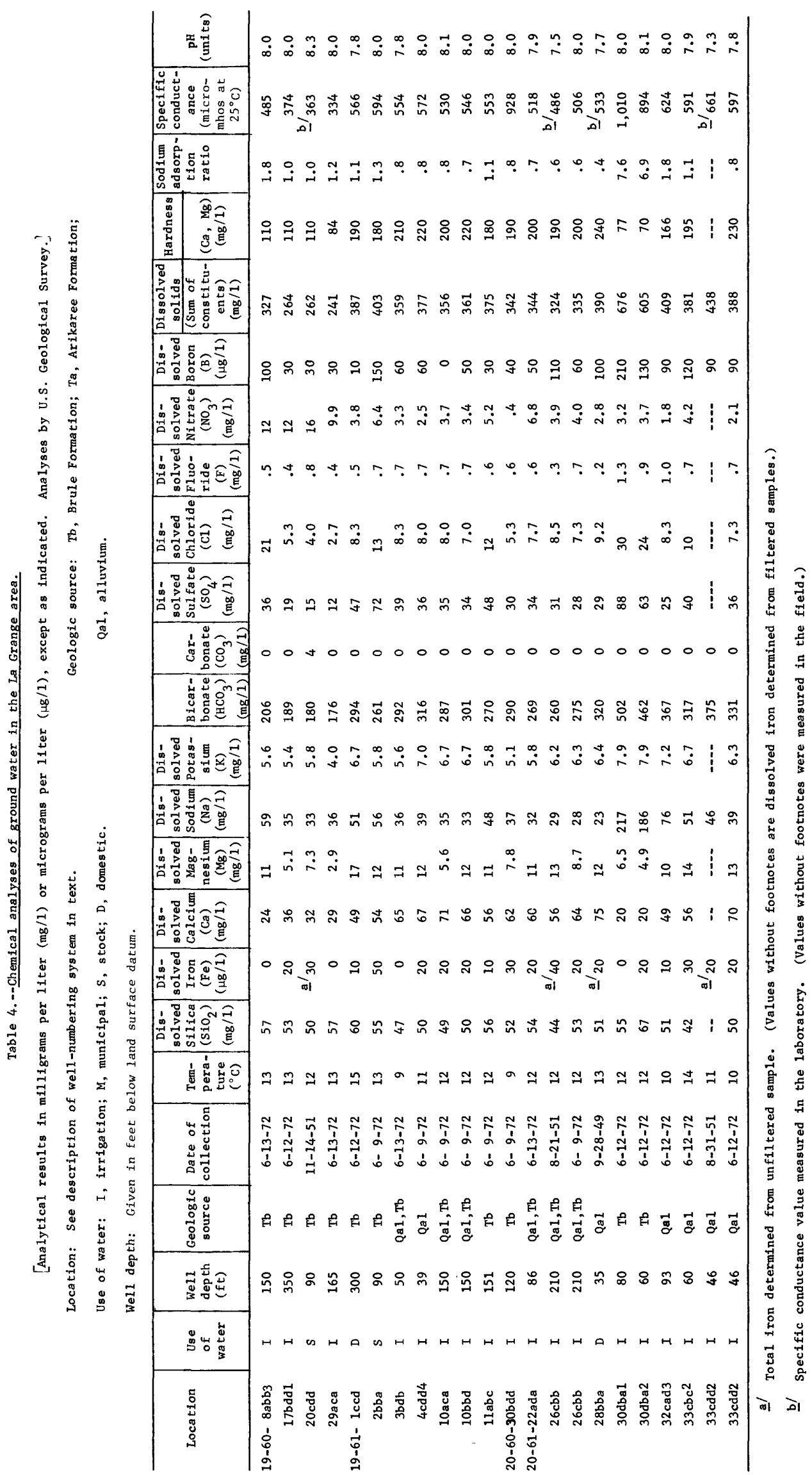




\section{Summary and Conclusions}

Irrigation wells in the La Grange area are developed in the Brule Formation, in the overlying alluvium, and in both the Brule and alluvium. Because the Brule generally consists of argillaceous siltstone, wells must penetrate zones of secondary permeability in order to obtain adequate quantities of water for irrigation. Zones of secondary permeability in the Brule in the La Grange area apparently are associated with ancient drainages and topographic features. For example, irrigation wells drilled in the Brule outside of the boundaries of the alluvium do not have yields as large as most irrigation wells drilled in the Brule in areas where the alluvium is present.

Acoustic borehole televiewer logs and other geophysical logs have been used in the La Grange area to define the location, distribution, and nature of secondary porosity of the Brule in two wells. Secondary porosity as shown on the televiewer logs was distributed randomly or appeared to be developed along bedding planes. Logs indicated that zones of secondary porosity predominate in the upper $80 \mathrm{ft}(24 \mathrm{~m})$ of the aquifer and that the upper 80 feet $(24 \mathrm{~m})$ of aquifer has a higher clay content than the rest of the aquifer. Parker (1963) stated that piping occurs most commonly in rocks in which montmorillonite is the dominant constituent. The clay in the Brule is a montmorillonitic clay. Therefore, higher clay content in the zones of secondary porosity supports the piping theory for the development of secondary porosity in the Brule. In the La Grange area drillers have described the zones of secondary porosity in several wells between 40 and $60 \mathrm{ft}$ (12 and $18 \mathrm{~m}$ ) and between 90 and $110 \mathrm{ft}(17$ and $34 \mathrm{~m})$, as zones of broken hardpan, creviced hardpan, and broken Brule. These porous zones, possibly associated with fracturing in the Brule, are zones of secondary permeability and they yield large amounts of water to wells. The presence of soluble minerals in the Brule indicates that development of secondary permeability in the Brule could have been, at least in part, assisted by solution activity. Thus, it is possible that before deposition of the alluvium, conditions were favorable for the development of secondary permeability by some combination of piping, fracturing and solution activity.

From 1972 through 1974, water levels were measured monthly in 24 observation wells, including two wells equipped with water-stage recorders. Monitoring of water-level fluctuations continues, using most of the established observation-well network. 
Increased ground-water withdrawals since 1968 in the area north and northeast of La Grange have not caused water-table declines as might be expected in an area of rapid development. Instead, the water levels rose about $5 \mathrm{ft}(2 \mathrm{~m})$ from the spring of 1970 to the spring of 1974 . Total estimated ground-water pumpage by wells north and northeast of La Grange from 1972 through 1974 was about 6,900 acre-ft $\left(8.5 \mathrm{hm}^{3}\right)$. Some of this water, which was not used consumptively, returned to the aquifer. The amount of surface water diverted during the same period by Horse Creek No. 1 Ditch was estimated to be 6,830 acre-ft $\left(8.4 \mathrm{hm}^{3}\right)$, most of which recharges the ground water in the area of pumpage. Precipitation also adds recharge to the area. Thus total recharge probably exceeds total discharge in this area, which results in rising water levels. However, in the spring of 1975 water levels were about 2 to $6 \mathrm{ft}(0.6$ to $2 \mathrm{~m})$ lower than those in the spring of 1974 . The high water levels in the spring of 1974 were caused by recharge from surface water and recharge from above-average precipitation during 1973. Belowaverage precipitation during 1974 and decreased surface-water diversions by Horse Creek No. 1 Ditch, especially during the latter half of 1974 , resulted in lower water levels in the spring of 1975.

Seasonal fluctuations of the water table in the area north and northeast of La Grange are as much as $9 \mathrm{ft}(3 \mathrm{~m})$. Precipitation and surface-water recharge cause the water table to rise in the spring, and pumpage during the irrigation season causes the water table to decline during the summer and fall. Without surface-water recharge in this area, water-level declines during the irrigation season would be greater than at present, and annual declines also might occur.

Between Horse Creek and Bear Creek, water levels declined 2 to $3 \mathrm{ft}$ $(0.6$ to $0.9 \mathrm{~m})$ from the spring of 1973 to the spring of 1975 . West of Bear Creek during the same period, water levels declined 2 to $4 \mathrm{ft}$ $(0.6$ to $1 \mathrm{~m})$. These water-level declines in both areas are mostly a result of irrigation wells being pumped almost 50 percent more during 1974 than 1973. Increased pumpage and decreased precipitation in 1974 caused lower spring water levels in 1975.

In the area west of Horse Creek, seasonal fluctuations of water levels are about $5 \mathrm{ft}(2 \mathrm{~m})$. Fluctuations at well 20-61-33ccb are as much as $7 \mathrm{ft}(2 \mathrm{~m})$. Most of the wells between Horse Creek and Bear Creek and also just west of Bear Creek have shallow water levels ranging from 2 to $12 \mathrm{ft}(0.6$ to $3.7 \mathrm{~m})$ below land surface. Thus, the water table here is affected by evapotranspiration and responds more quickly to recharge from precipitation and surface-water irrigation than wells north and northeast of La Grange. 
Streamflow measurements during July 1973 indicate that Horse Creek is a gaining stream in the reach below Horse Creek No. 1 Ditch. Pumping from irrigation wells to the west would seemingly cause streamflow depletion along the reach; however, recharge from precipitation and surface-water irrigation apparently are sufficient to maintain the water table at a level above the stream during the irrigation season. It seems unlikely that pumping from irrigation wells along this reach of Horse Creek has caused significant direct streamflow depletion.

Comparison of the analyses for four ground-water samples collected in 1949-51 with analyses of ground-water samples collected in 1972 indicates that, at least locally, irrigation has not caused any significant changes in water quality. Dissolved-solids concentration in water from wells developed only in the alluvium ranged from 359 to $438 \mathrm{mg} / 1$ and in water from wells developed only in the Brule Formation from 241 to $676 \mathrm{mg} / 1$. 


\section{REFERENCES CITED}

Adams, G. I., 1902, Geology and water resources of the Patrick and Goshen Hole quadrangles, in eastern Wyoming and western Nebraska: U.S. Geol. Survey Water-Supply Paper 70, 50 p.

Babcock, H. M., and Rapp, J. R., 1952, Reconnaissance of the geology and ground-water resources of the Horse Creek-Bear Creek area, Laramie and Goshen Counties, Wyoming: U.S. Geol. Survey Circ. $162,28 \mathrm{p}$.

Bjorklund, L. J., 1959, Geology and ground-water resources of the upper Lodgepole Creek drainage basin, Wyoming: U.S. Geol. Survey WaterSupply Paper 1483, 40 p.

Crist, M. A., and Borchert, W. B., 1972, The ground-water system in south-eastern Laramie County, Wyoming: U.S. Geol. Survey open-file rept., $49 \mathrm{p}$.

Denson, N. M., and Bergendah1, M. H., 1961, Middle and upper tertiary rocks of southeastern Wyoming and adjoining areas, in Geological Survey Research 1961: U.S. Geol. Survey Prof. Paper 424-C, p. C168-C172.

Dockery, W. L., 1940, Underground water resources of Horse Creek and Bear Creek valleys, southeastern Wyoming: Wyoming Geol. Survey Bu11. 30, 32 p.

Fenneman, N. M., 1946, Physical divisions of the United States: U.S. Geol. Survey Map.

Ferris, J. G., and others, 1962, Theory of aquifer tests: U.S. Geol. Survey Water-Supply Paper 1536-E, 174 p.

Jacob, C. E., 1950, Flow of ground water, chap. 5, in Engineering hydraulics, Hunter Rouse, editor: New York, John Wiley \& Sons, p. 321-386.

Jenkins, C. T., 1970, Computation of rate and volume of stream depletion by wells: U.S. Geol. Survey Techniques Water-Resources Inv., book 4, chap. D1, $17 \mathrm{p}$.

Keys, W. S., and MacCary, L. M., 1971, Application of borehole geophysics to water-resources investigations: U.S. Geol. Survey Techniques Water-Resources Inv., book. 2, chap. EI, 126 p.

Lowry, M. E., 1966, The White River Formation as an aquifer in southeastern Wyoming and adjacent parts of Nebraska and Colorado, in Geological Survey Research 1966: U.S. Geol. Survey Prof. Paper 550-D, p. D217-D222. 


\section{REFERENCES CITED--continued}

Lowry, M. E., and Crist, M. A., 1967, Geology and ground-water resources of Laramie County, Wyoming: U.S. Geol. Survey Water-Supply Paper $1834,71 \mathrm{p}$.

Meyboom, P., 1961, Estimating ground-water recharge from stream hydrographs: Jour. Geophys. Research, v. 66, no. 4, p. 1203-1214.

Parker, G. G., 1963, Piping, a geomorphic agent in landform development of the drylands: Internat. Assoc. Sci. Hydrology, Pub. 65, p. 103-113.

Rapp, J. R., Visher, F. N., and Littleton, R. T., 1957, Geology and ground-water resources of Goshen County, Wyoming: U.S. Geol. Survey Water-Supply Paper 1377, 145 p.

Schlaikjer, E. M., 1935a, The Torrington member of the Lance formation and a study of a new Triceratops, Pt. 2 of Contributions to the stratigraphy and paleontology of the Goshen Hole area, Wyoming: Harvard Col1. Mus. Comp. Zoology Bull., v. 76, no. 2, p. 31-68.

1935b, A new basal oligocene formation, Pt. 3 of Contributions to the stratigraphy and paleontology of the Goshen Hole area, Wyoming: Harvard Coll. Mus. Comp. Zoology Bull., v. 76, no. 3, p. 69-97.

$1935 c$, New vertebrates and the stratigraphy of the 0ligocene and early Miocene, Pt. 4 of Contributions to the stratigraphy and paleontology of the Goshen Hole area, Wyoming: Harvard Coll. Mus. Comp. Zoology Bu11., v. 76, no. 4, p. 97-189.

Smith, F. A., and Souders, V. L., 1971, Occurrence of ground water in Kimbal1 County, Nebraska including logs of test holes: Univ. Nebraska, Conserv. and Survey Div., Water Survey Paper 29, 135 p.

Stallman, R. W., 1971, Aquifer-test design, observation and data analysis: U.S. Geol. Survey Techniques Water-Resources Inv., book 3, chap. B1, $26 \mathrm{p}$.

Theis, C. V., 1935, Relation between the lowering of the piezometric surface and the rate and duration of discharge of a well using ground-water s.torage: Am. Geophys. Union Trans., pt. 2, p. 519-524. (Also as U.S. Geol. Survey Ground Water Note 5, 1952.)

U. S. Department of Commerce, 1949-74, Climatological Data; National Oceanic and Atmospheric Administration: Washington, U.S. Govt. Printing Office. 
U. S. Geological Survey, 1966-73, Water resources data for Wyoming: Part 1, Surface-Water Records 1966-73, and Part 2, Water-Quality Records, 1970-72: " Cheyenne, Wyo.

Walton, W. C., 1962, Selected analytical methods for well and aquifer evaluation: Illinois State Water Survey Bull. 49, 81 p.

Weeks, E. P., 1964, Hydrologic conditions in the Wheatland Flats area, Platte County, Wyoming: U.S. Geol. Survey Water-Supply Paper 1783, $79 \mathrm{p}$.

Whitcomb, H. A., 1965, Ground-water resources and geology of Niobrara County, Wyoming: U.S. Geol. Survey Water-Supply Paper 1788, 101 p. 